
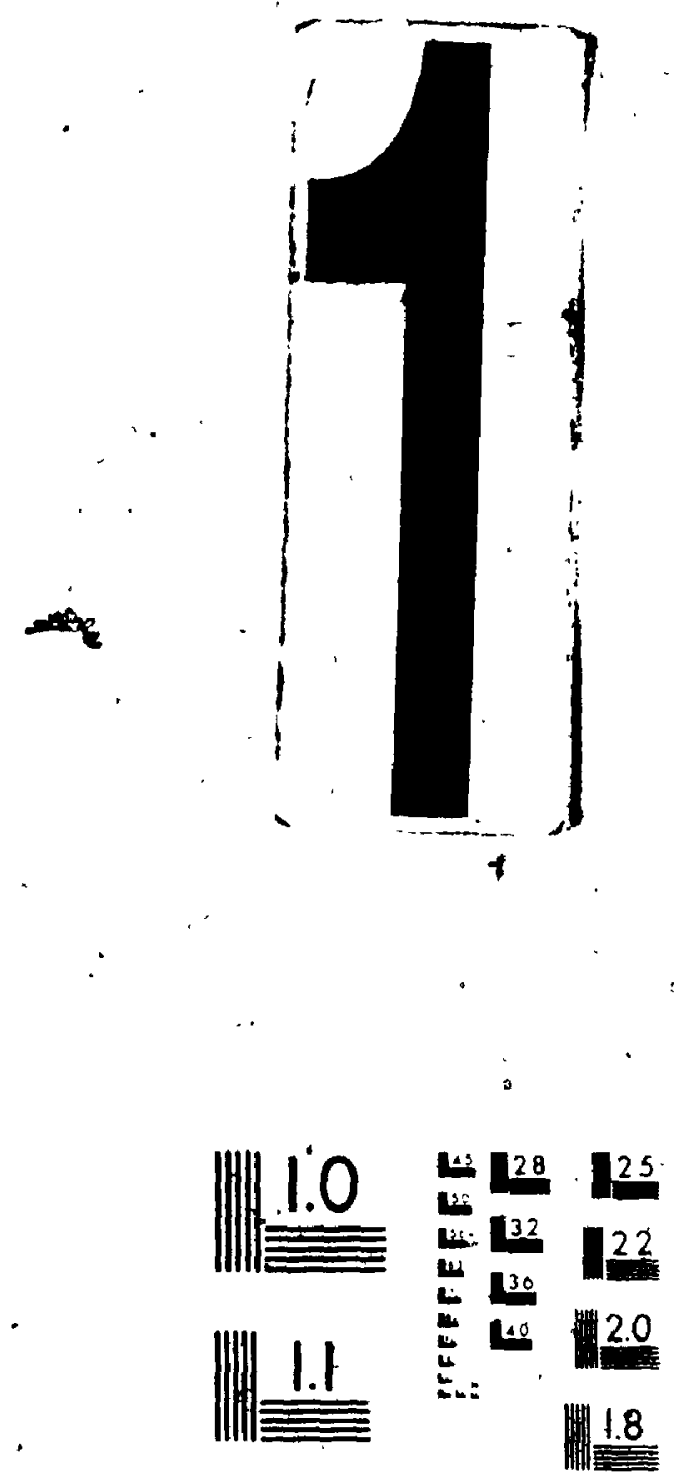

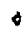
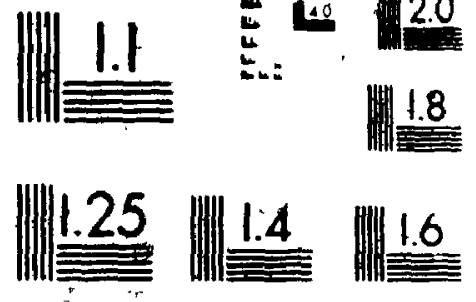

MICAOCOPY RESOLUTHON TEST CHART

NATIONAL BUREAU OF STANOAROS

STANDAAD REFERENCE MATERIAL 10100

ANSI And ISO TEST CHAAT NO ?!

4

$+$ 
of Canada

Cariadian Theses Service

Onawa, Canada

K1A ON4

6

\section{CANADIAN THESES}

Bibliotheque nationale

dú Canada

Services des mésés canadiennes

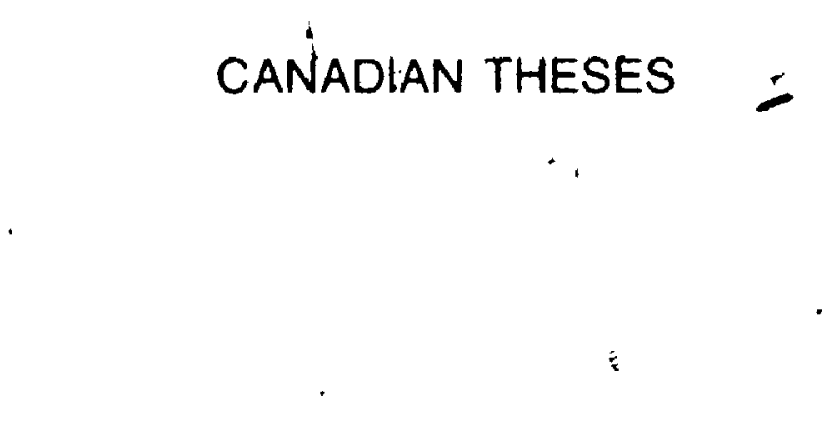

NOTICE

The quality of this microfiche is heavily dependent upon the quality of the original thesis submitted for microfilmıng Every effort has been made to 'ensure the highest quality of reproduction possible

If gages are missing, contact the univer sty which granted the degree

Some pages may have indtstinct print espectalty if the onginal plages were typed with a poor typewruer fijbon or if the university sent us an interior photocopy

Previously copyrighted materials foumal articles, oublished tests, etc) are not fitmed.

Reproduction in lutt or in part of this film governed by the Canadian Copyright Act, R S C .1970, c C. 30
\%

n

THĖSES CANADIENNES
AVIS

La qualté de cente microfiche dépend grandement de la qualité de la these soumise au microlimage Nous avons lout lall pour assurer une qualite superieure de feproduction

Sill manque des pages. veuillez communiquer avectunversité qui a contéré le grade

La qualité dimpression de certaines pages peut laisser a désirer, surtout si les pages originales ont éle dactylographıees á l'aide d'un ruban usé ou sı l'untversité nous a lait parvenir une photocopie de qualite interreure

Les documents qu lont dejá l'objel d'un dront d'auteur (articles de revue. examens publies, elc) ne sont pas microfilmés

La reproduction. même partielle, de ce microfitm est soumise à la Lor canadrenne sur'te dront deauteur. SAC 1970. c C.30

\section{THIS DISSERTATION HAS BEEN MICROFILMED EXACTLY AS RECEIVED}



Permission has been granted to the National Library of Canada to microfilm this thesis and to lerid or sell. copies of the film.

The author (copyright owner)' $h$ as reserved other publication rights; and neither the thesis nor extensive extracts from.. it may be printed or otherwise reproduced without his/her written. peeryission:
L'autorisation a été. accordée a la Bibliotheque nationale du Canada de microfilmer cette thèse et de prêter ou de vendre des exemplaires du film.

L'auteur (titulaire du drolt d'auteurl. se reserve les autres aroits de publication; ni la. these ni de longs extraits de celle-ci ne doivent etre imprimés ou autrement reproduits sans son autorisation écrite.

IS $3 . v \quad 6-315-33413-4$ 
The undersigned recommend to the Faculty of Graduate Studies and Research acceptance of the the is

A CLIMATOLOGICAL ANALYSIS OF EASTERN CANADIAN SEABOARD MAXIMUM ICE EXTENT USING PASSIVE MICROWAVE SATELLITE DATA (1973-1985)

: Submitted by Anne Elizabeth Walker B.A. Carleton University'

in partial fulfilment of the requirements for $\hookrightarrow$ the degree of Master of Arts

0

Heel

THESIS SUPERVISOR

$\frac{\text { lain Wal tace }}{\text { CHAIRMAN, DEPARTMENT OF GEOGRAPHY }}$

Carleton University

September 1986

1 

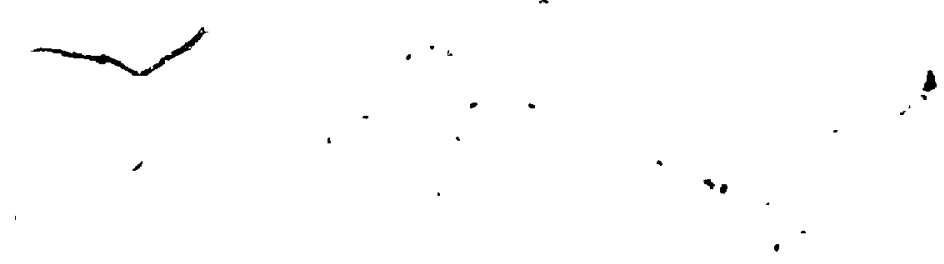

ABSTRACT

Values for Eastern Canadian Seaboard maximum sed ice drea and. extent are derived from Nubus-5 Electrically iscanniny Microwave Radometer (ESMR) and Nimbus-7 Scanńing Multichannel Microwave Radometer (SMMR) satelltte passive microwave data. Interannual variation in maximum i.ce extent i.s investigated covering the 13 years (1973-1985) of archived data, through comparisons to several climatological and oceanographic variables. The objective is to account for the variation seen in the maximum ice values, and attenpt to isolate $\because "$ any controlling parameters. Trends in seasonal (winter) alr tomperature ineans, freezing deyree day accumiulations and sea surface temperature anomalies exhibit the highest correlations with the maximum ice extent and area trends. Comparison with lcelandictow winter positions does not yield a significant correlation, suggesting that the role of atmosphere-ocean interaction In deterpining maximum ice extent bejars further research. 


\section{ACKNUWLEUGEMENTS}

There are several peopla who warrant acknowledgement for the ir he! $p$ in the development of this thesis. Foremost, Or. Rene 0. Bamseier, in nis role as thesis supervisor and advisor, provided critical input at every stage of the research; from the refining of initial ideas to the review of the final araft. After. five years of being involved in passive microwave research; Dr. Ramseier has continued to influence me in brodening my horizons concerning pasşive microwave remote sensing applications, of which this thesis is an example.

The passivemicrowave products were provided by Ph.D. Associates int. Dr. Frank Thirkettle was responsible for the computer-generation - of maps and statistics." The "AES/Ph.D. algorithm was developed by Mrs. Irene Rubinstein. A special thank you also goes to Dr. Frank Bunn, President, for supporting my research work over the past several years, and thus giving me the opportunity to increase my expertise and capollities in passive microwave remote sensing research.

Mr. Fred leddes of the Ice Climatology and Applications Division of Environment Canada's Ice Centre was very helpful in the accessing of cllratological and ice information needed. for the analysis portion of this thesis. A thank you a 1 so goes to Professor Mike Fox for reading the thesis draft and providing excel lent editiorial advice.

Finally, an important thank you goes to my husband, Peter, for his continuous moral support and encouragement in my research endeavours. His help in drafting the final illustrations was greatly apprectated. 

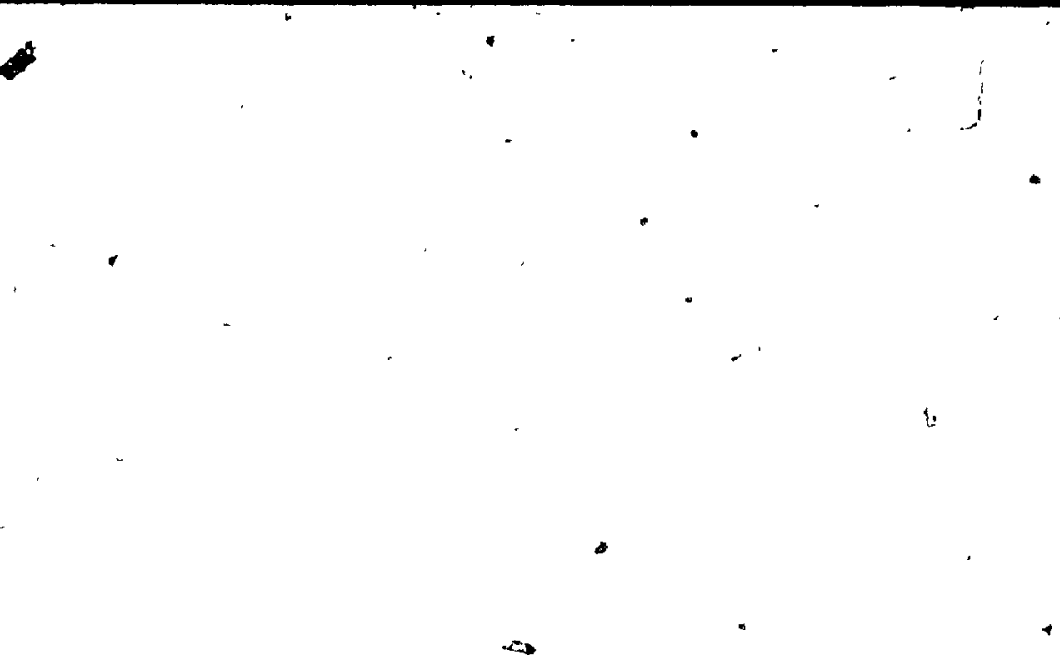

TABLE OF CONTENTS

Paye

ACCEPTANCE .SHEET $\ldots \ldots \ldots \ldots \ldots \ldots \ldots \ldots \ldots \ldots \ldots \ldots \ldots \ldots \ldots \ldots \ldots \ldots \ldots, \ldots$

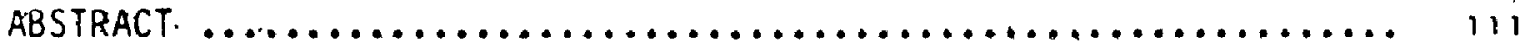

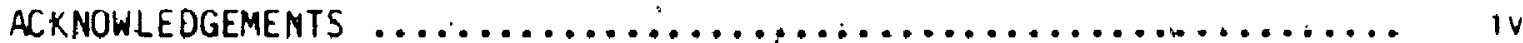

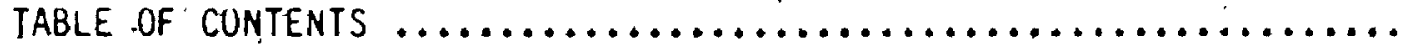
LIST OF 'TABLES

LIST UF FIGURES

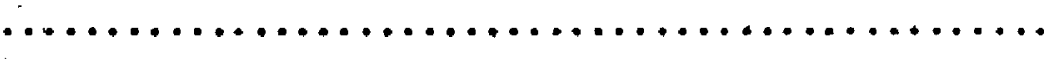

CHAPTER 1: Introduction

4.

1.1 General Background

1.2 Goals and Objectives

1.3 Thesis Organization

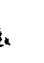

$211^{*}$

$v+11$

CHAPTER 2: Theorętical Background

2.1 Development "of Satellite Passive Mricrowave Remote Sensing . 6

2.1.1 Nimbus -5 and ESMR ....................... 6

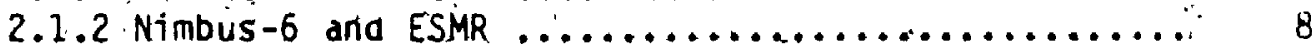

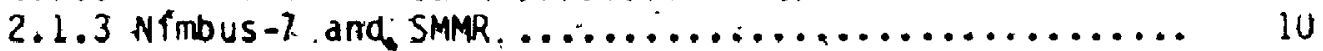

2.2 Pas'sive Microwave Remote Sensing ..................... 11

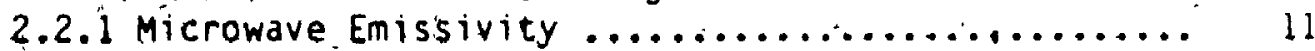

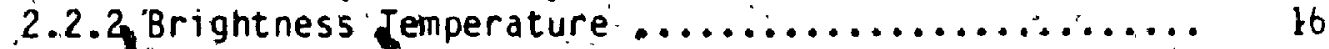

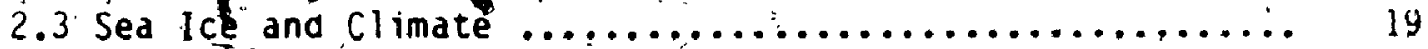

2.3.1 Sea Ice and Atmospheric Lnteractions ............ 14

- 2.3.2 Sea Ice Parameters of Climatic Interest .......... 21

2.3.3 Role of Passive Microwave Data ............... 22

CHAPTER 3:" Characteristics of the Eastern Canadian Seaboard

3.1 Definition of the Study Area ....................... 24

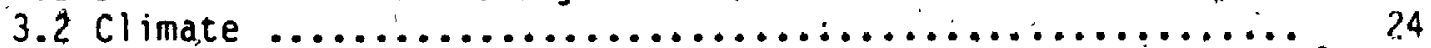

3.2 .1 Air Temperatkre ....................... 24

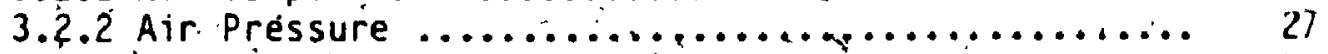

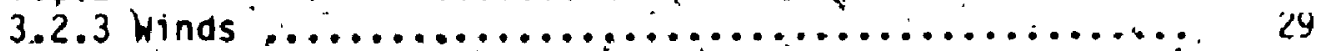

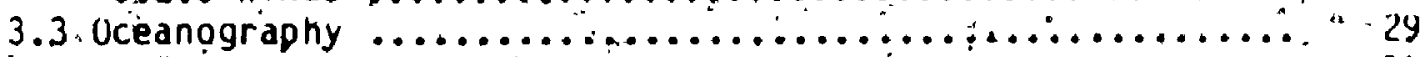

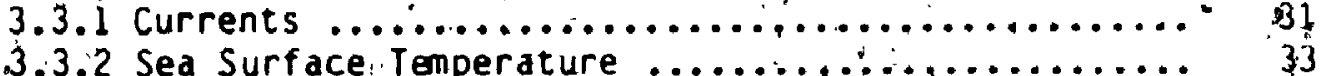

3.3 .2 Sea Surfar
3.4 Sea I cér. Regine

Sea I ce Regine ..............................

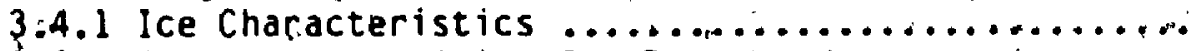

3.4.2 Factors Uetermining Ice Extent ................ 36 
CHAPTER 4: Aadysis of Interannual Sea Ice Variation

4.1 Format of the Passive Microwave Data ................. 39

4.2 Sea Ice Algorithms ............................. 40

4.2 .1 Simple Linear.Algorithm .................... 40

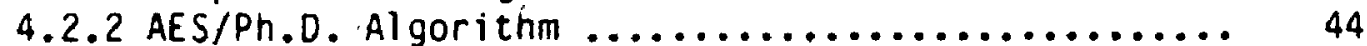

4.3 Display of the Ice Concentration Data ................ 46

4.4 Analysis Methodology for Interannual Variation .......... 47

4.4.1 Dates of Maximum Ice Extent .................. 47

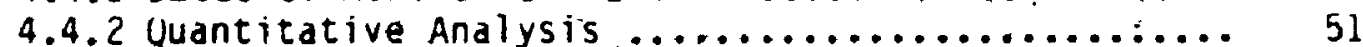

4.4.2.1 Methodolagy of Statistics Derivation ...... 51

4.4.2.2 Computer and Manual Statistics Derivation. 52

4.4.2.3 Trends in Ice Area and Extent ............ 54

4.5 Validation of I ce Area and Extent Trends ............... 54

CHAPTER 5: Explanation of Séa Ice Interannual Variation

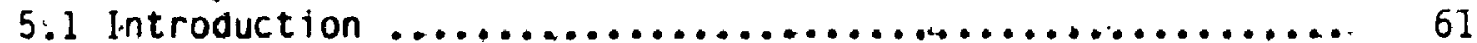

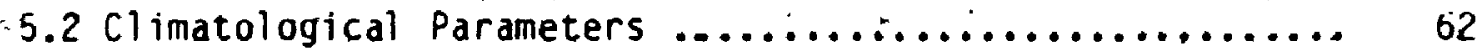

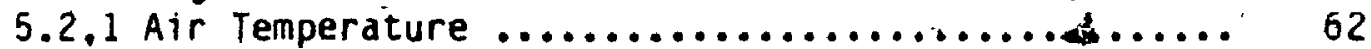

5.2.2 Accumulated Freezing Degree Days ............... 67

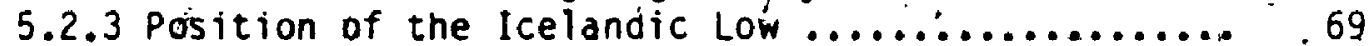

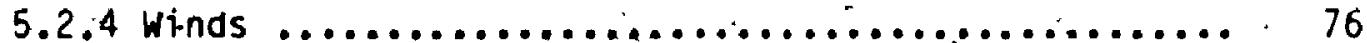

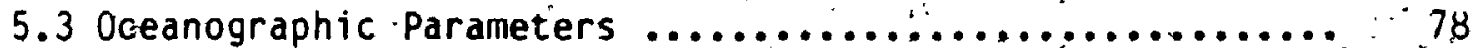

5.3 .1 Sea Surface Temperature .................... " 78

5.4 Significance of the Climatological and Oceanographic-

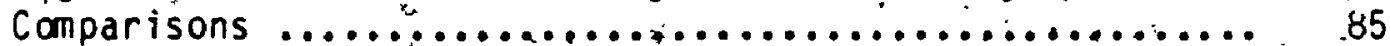

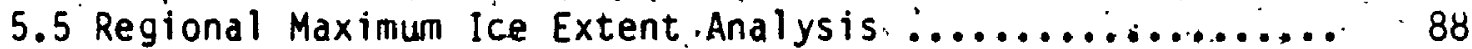

5.6 Climatic Significance of Maximum lce Exfent Frends ...... 92 .

CHAPTER $6::^{\circ}$ Concluain Remarks

- 6.1 Sumary of the Interannual Variability Arialysis ........ . 95

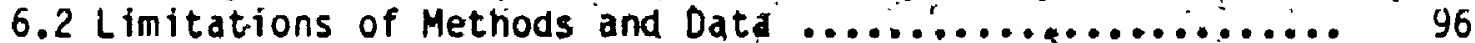

6.3 Implications for the Canadian Off shore 'Scenario ......... 97

. 6.4 Applications to Climate Research....................... 98

6.5 The Future of Passive Microwave Satellite Remote Sensing 99

APPENDIX A.1: Maps Displaying Maximum Içe "Extent Conditfons

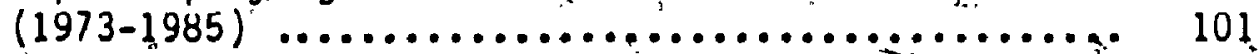

APPENDIX A.2: ICe Area and Extent Statistics (1973-1985) ........ 114

APPENDIX A.3: Air Temperature and FDD Data for Meteorological

Stations Along the Eastern Canadian Séaboard ....... 117

APPENDIX A.4: Accessibllity of Nimbus-5 ESMR. and Nimbus-7 SMMR

Data

BIBLIOGRAPHY 
TABLE: DESCRIPTION

PAGE

:. 1

History of Satellite Passive Microwave Remote Sensiny ..

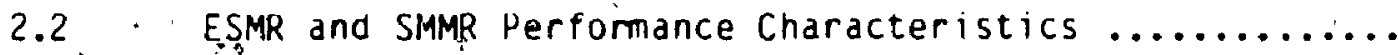

Maximum Ice Extent ánd Area Values (1973-1985)

bo

5.1 Easterń Canađian Seaboard February and March Mean Air Temperatares $\left({ }^{\circ} \mathrm{C}\right)(1973-1985)$

Eastern Canadian Seaboard Seasonal Air Temperature Means (December to February, 1973-1985)

5.3 Freezing Degree Day Accumulations for the Eastern

Canadian Seaboard to the End of February (1973-1985)

:5.5 .. February Prevailing Wind Directions and Speeds (km/hr) $(1973-1985)$

5,6. : Sea Sürface Temperature Anomalies $\left({ }^{\circ} \mathrm{C}\right)$ for the Eastern Canadian Seaboard (1973-1982)

5.7 Maximum Ice Extent and Areavalues for the Eastern "Canadian Seaboard Regions (1979-1985)

vii. 


\section{LIST UF FIGURES}

FIGURE DESCRIPTION

PAGE

2.1 Emissivity vs Frequency Relationship for Sea Ice Types

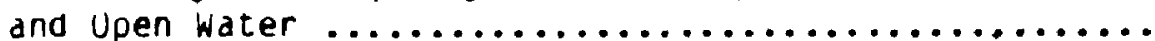

2.2a The Physical Propertiès of First Year Ice ............... 14

2.20 The Physical Properities of 0ld Ice ................ 14

2.3 The Radiative Transfer Equation ................. 18

2.4 The Atmosphere-Ocean Energy Balance System ........... 20

3.1 The Eastern Canadian Seaboard and Subregions .......... 25

3.2 Eastern Canadian Seaboara Air Temperature Statistics ... 26

3.3 Typical Winter Surface Pressure Distribution for Eastern Ganada .................................... 28

3.4 Typical winter Edst coast wind velocities ............ 30

3.5 Major Ocean Currents Along the Eastern Canadian Seaboard 32

3.6 Typical Winter Sea Surface Temperatures Along the

Edstern Canadian Seaboard ....................... 34

4.1 The Simple Linear Algoritnm ................... 41

4.2 The Increase in $T_{B}$ at $19.35 \mathrm{GHz}$ Caused by wind Speed Uver an. Ocean surface ......................... 43

4.3 The AES/Ph.D. Algorithm .......................... 45

4.4 Example of Map Portraying Passive Microwave Derived Ice Concentrations .............................. 48

4.5 Extremes in Maximum Ice Extent Position (1973-1985) .... 50

4.6 Eastern Canadian Seaboara Maximum Ice Area and Extent $(19.73-1985)$

4.7 Example of Eastern Canadian Seaboard Poption of a $i$ British Meteorological Office Ice Chart (February 1984) 
Maximum Ice Extents and Arejis from British Meteor- ological Office (BMO) Ice Charts as Compared to Passive Microwave Trends (1974-1984)

5.1 Trends in Ice Area and Extent Compafed to February arid March Mean Air Temperatures (1973-1985) ............. 64

5.2 Trends in Ice Area and Extent Compared to Seasonal (Winter) Air Temperatures $(1973-1 \otimes 85)$................ 68

5.3 Trends in lce Area and Extent Compared to Eastern - Canadian Seaboard FUD. Accumulations (1973-1985) ........ 71

5.4 Mean January-February Position of the Icelandic Low

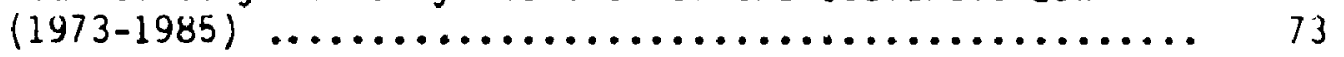

5.5 The NAFO Convenţion Area $\ldots \ldots \ldots \ldots \ldots \ldots \ldots \ldots \ldots \ldots \ldots . . \ldots$

5.6 Trends in Ite Area and Extent Compared to East Coast Wea Surface Temperature Anomalịes (1973-1982) ........... 83

5,7 Annual Sea Surface Temperture Anomalies for the Eastern - Canadian Seaboara (1972-1983) 84.

5.8 Easteirn Canadian Seaboard Regional Trends in Maximum Ice

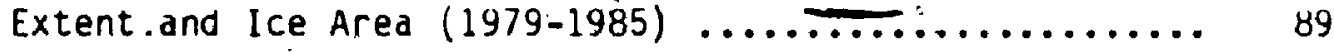

5.9 Median Maximum Ice Extents from AES lce Charts (1963-1973) and Passive Microwave Data (1973-1985) 


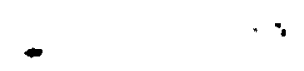

CHAPTER 1

\section{INTROOUCTIUN}

\section{$\int 1.1$ General Background}

Uver the past several years, the East Coast region has become the vocus for offshore oil ana gas development. The presence of sea içe along the Eastern Canadian Seaboard during the winter months presents a barrier and hazard to offishore operations. The variability in ice congitions and extent from year to year makes it difficult to predict to what extent operations will be affected during the season. If the foretalt of even greater activity in the Eastern offshore becomes reality, it will be necessary to obtain a greater understanding of ice limits and variaditity in this region. The need of a greater understanding of East Coast maximum ice extent has been emphasized recently by Wadhams and Lever (1989) in their preliminary science plan for the Labrador Ice Margin Experiment (LIMEX); due to take place in. 1987. They indicate that this type of research will lead to more efficient marine operations in the Eastern Canadian offshore waters.

Satellite remote sensing provides one of the best sources of information for sea, ice reconnalssance; by allowing one to view large areas of the edrtn's surface instantaneasly. Surveillance of remote regions, inaccessible by traditional reconnaissance methods, is therefore ppssible an a daily basis. Passive microwave metriods have the 

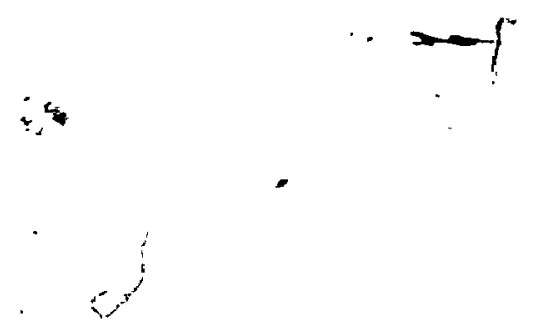

advantages of day ana night sensiag capability tarid the ability co penetrate clouds, haze ana most forms of precipitation. These auvantages.make passive microwave sensing very effective for sed lce studies, since many ice-coverea regions are in total darkness for part ut the year. The East coast reyion is subject to stormy, unsett leo wedifler during the winter months, in some cases to the degree ds to innioit visual ice reconnaissance. In fact, in the winter months the reyion may De totally obscured by cloud or foy ger $50 \%$ of the time liustajtis. 1979). Passive microwave sensors are therefore particularly sulted to monitoring sea ice on this area; by providing the all-weather capability) to supplement traditional aerial reconnaissance (Mullane, 1980$)$.

The launch of the Electrical ly Scanning Microwave Radiometer (ESMK)'. on board NASA's Nimbus-5 satellite in 1972. signalled the beginning of continuous monitoring of the earth's surface using a passive microwave - Sensor. The Ialunch of the Nimbus-7 Scanning Multichannel Microwave Radometer (SMMR) in ly78 ensured the continuation of passive microwave satellite sensing. The SMMR is still in operation today. Therefore the data set that has been accumulated from the two sensors spans over 13 yearsw(1972-1986): The archived data, stored on cemputer tape, can be d" useful data base for studies of regional or hemispheric lce conations, especially studies of interannual variablity.

Sea ice plays an important role in the global climate system. The areal extent of ice covering the oceans affects the global heat budget, as it prevents heat from escaping from the oceans to the atmosphere.: The interannual variability of sea ice extent can be an important 



\section{1}

(1.e., corrulation) and visual (qualitative) examination of the data:

A secondary goal of the thesis is to lliustrate the usefulnoss of sea icé inforllation, derivea from satel lite passive microwave data, to climate stirdies. Sea ice plays an important role in the global climate systerr, and satellites can provide consistent and reliable information about global sed ice limits (European Space Agency, 1985). Sgea ice concentrations derived from pasšive microwave data, can be an important input to climate models, leadjny to a greater understanding of sed ice and climate interactions.

\subsection{Thesis Orgenization}

The fallowing chapters lead through consecutive stages of the 4. research by providing ackground material, details of the analytical - procedures and discussion of the subsequent results. Chapter 2 focusses on the history and theoretical basis of satellite passive microwave remote sensing, with respect to sea ice research. The rmportance of sed ice within the climate scenario is al so outlined, emphasizlny the role of passive microwave data to sea ice/climate stuajes. Chapter 3 preserits a description of the climatic and oceanographic nature of the Eastern Canadian Seaboard around the time of maximum jce extent. The typical sedice regime 35 also described, and tactors believed to at. influence maximum ace extent are out l ned. Chapter 4 focusses on the analysis methodalogy by first discussing the derivation of ice concentrations from the passive microwave data. The generation of maximum sea ice area and extent values for each xear, 1973 to 1985, from the ice concentrations is outlined. These values form the basis of the 
Interannual variability trend in maximum ice extent of the Eastern Canadtan Seaboarg. Chapter 5 compares the trend in maximuin ice extent to the climatological and oceanographic parameters. Chapter 6 summarizes the research presented in the preceding chapters, and outlines the significance of the results to the East coast scenario. Areas of future reseach are also suggested in light of the future of satellite passive -.........$$
\text { s. }
$$
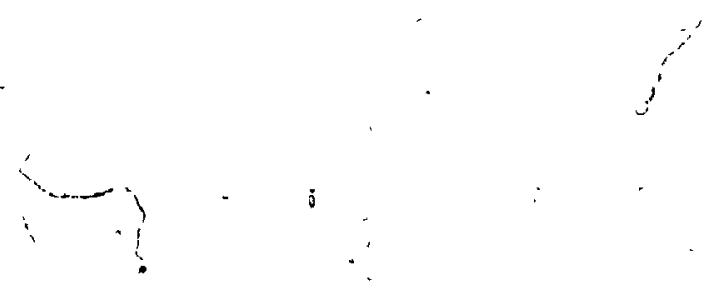

$\therefore$

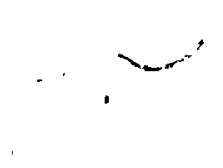

t?

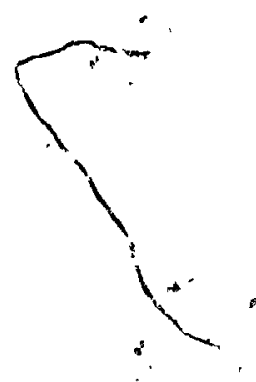

. 


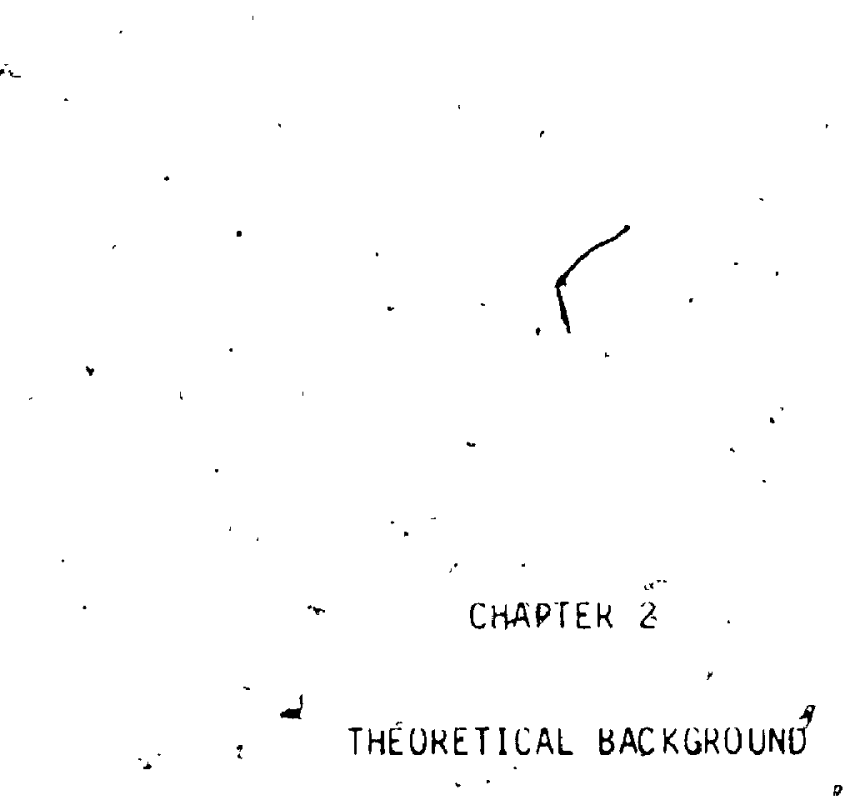

2.1 Developnenty of Satel lite Passive Microwave Remote Sensing

A review of passive microwave remote sensing of the earth trom space is g̈ıven by NJoku (1982). Table 2.1 summarizes the nistory ot microwave radiometry. on spacecraft, providing details of the inissions involved.

The, Soviet COSMOS satellites launched in 1968 and 1970 yielded the fifst recordings of passive microwave radiation from the eärth's surface at a ringe of frequencies from 3.5 to $37 \mathrm{GHz}$. Sea lce concentration was one of the parameters investigated during these missions (Noku* 1982).

The Ninbus series of satelities ( 5 through 7) Iaunched by NASA nas. given the most.extensive set of observations on recara beginning in 1972 until the present. Detalls regaraing these sateljites ana the results specific to sea ice research are oescrided in the following subsections.

\subsubsection{Nimbus-5 ana ESMR}

月

The Ninfus -5 satellite was launched on December 11,1972 with one . ef its sensors being the Electricalily Scannung Microwave Kadometer (ESMK). The ÉMR is a single frequenicy passive microwave radiometer, opdating at the $19.35^{\circ} \mathrm{GHz}$ frequency in the horizontal polarization, and 
$\%$

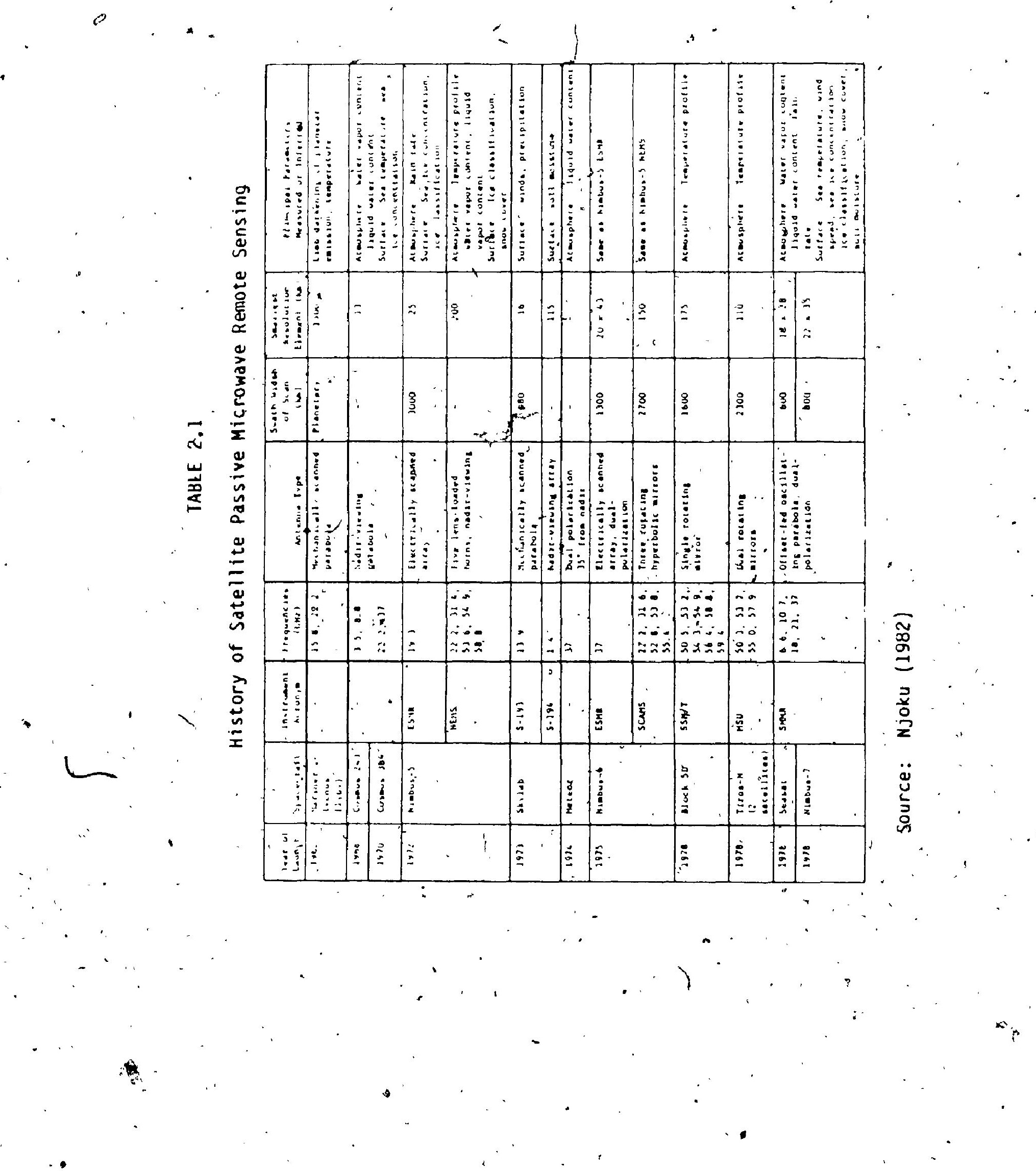


1

with a ground resolution of $30 \mathrm{~km}$. A list of its performance characteristics appears in Table 2.2 .

One of the main objectives of Ege ESMR was to provide data to inap the distribution of polar ice, by providing the first all-weather and a) 1 -season means of ice detection:. The microwave images produced trath the data had a great, impact on sea ice research. Zwally and Gloerson (1977) describe the reseacch applications of this inagery: Information concerning ice concentration and ice type withon the rcejpdck can be der rved, and temporal changes càn bé anal ysed from successive inayes.

The quality of the ESंMR collected data degraded somewhat after 1976, Dut the U.S. Navy consiaerea it to be reliable enough to use in compiling their operational ice charts until as late as 1980 (Eppler, 1983). One of the main drawbacks to the ESMK was that it only provided - information on a single frequency. In order to derive more parameters (a.e., to distinguish between ice types) a multifrequency sensor is needed.

\subsubsection{Nimbus-6 and ESMR}

$\varepsilon^{*}$. The second ESMR' to be put into space was on board the Nimbus -6 satelite launched in June 1975. It differed from the Nimbus-5 ESMR (see Table 2.2) in that. it operated at the $37 \mathrm{GHz}$ frequency, with dualpolarization (vertical and horizontal) capability. The significant aspects of these changes were that the higher frequency would result in an increase in contrast between first yeàr and old ice, and the dualpolarization would reduce the ambiguity in determining ice type and 
TABLE 2.2

ESMR and SMMK Perfórmance Characteristics

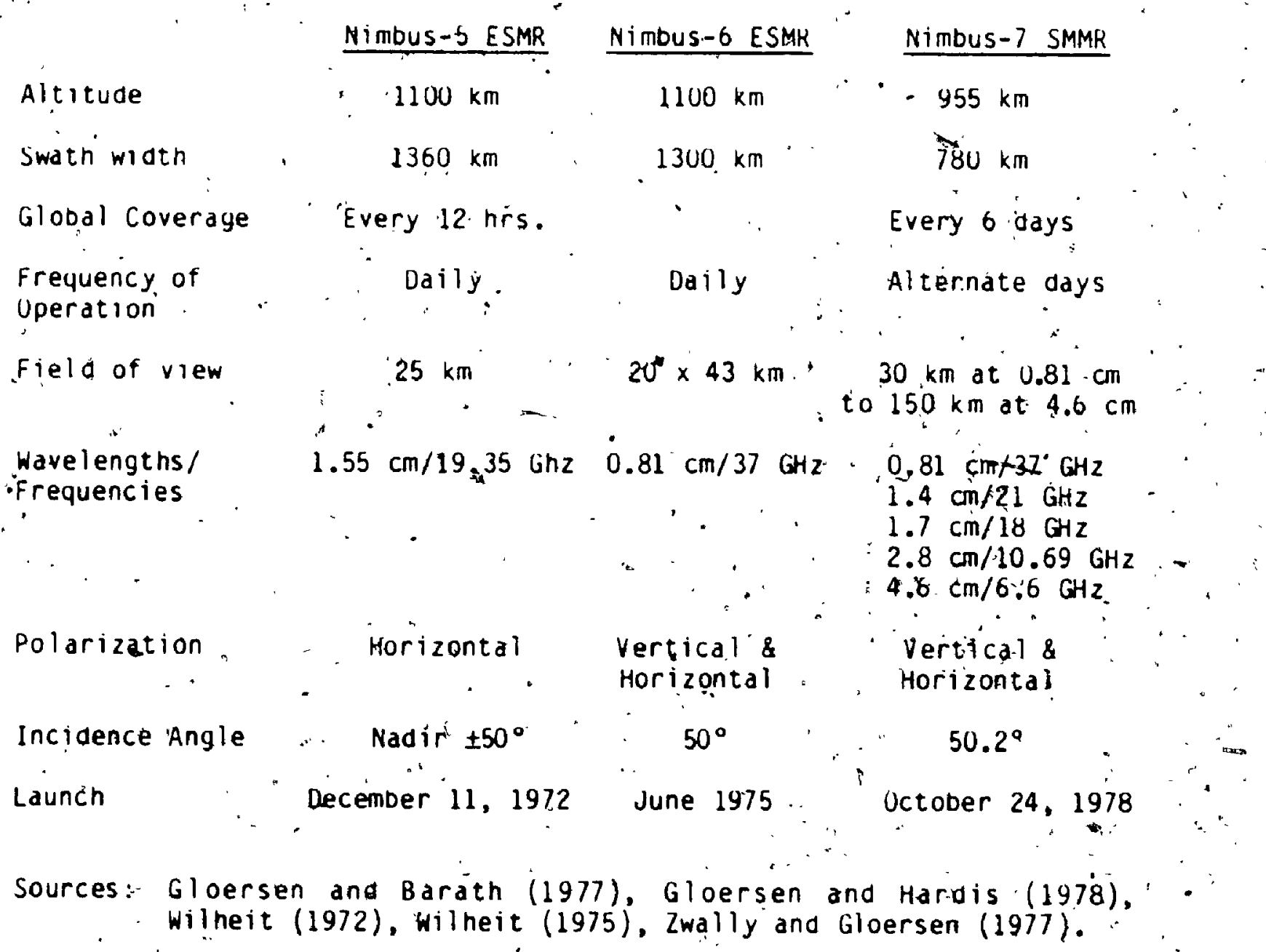


facilitate the quantitative interpretation of radiometric measurements (wilhert, ly7b).. In september "1976; the nogrzontal channel fathed. inus reducing the Nimbus-6 ESMR tio a single channe! sensor. The vertical channel failedabout a year after launch, thus enidng the life the sensor. Eppler (1983) states that although the datadé poteptially useful for sea ice mapping, the datạ. have not been arsed in poidr studies.

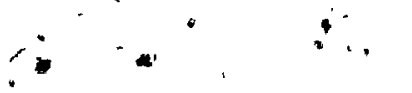

\section{.2 .1 .3 Nimbus-7, and SMMR}

Un victober 24, ig78 NASA launched the Scanning Milt tochaninel. Micruwave Raquometer. (SMMK.) on board the Nimbus-7 satellite.: The SMMR: with its five frequencies $(37,21, \alpha 8,10.69,6.7$ GH.z) and dud-polarization "(horizontal and vertical) system prokided a substantial increase in the amount of informatron available over the previous ESMR's:. The resodution of the data equal led that of the ESMR at. $30 \mathrm{~km}$ (for the highest frequency.channel). Table 2.2 out lines the sMMR's performance characteristics and provides a comparison. with the two ESMR's. G.toersen. ano Barath (1977) also provide a summary of the instrument's operating charaćteristics. Due to power restrictians on board the satellite, the SMMR onl y.operatés every other day (Gloersen and Hardis, 19ib).

The ability to discriminate between first year and old ice ano open watef within its fieto of view, is a sigṇificant advancement of the SMMK over the ESMR. The SMMR's multifrequency and dual-polarization characteristics allow for this discrtmination (Cavalieri et al. 1984). This abjlity has speçific application to any area containing more than one 


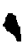

type of ice.

In recent years, there have been many: sed ice studies involving. SMMK data focussing: on different regions and different seasoris. Sane significant ones include Cavalierí et al. (1983), Comiso (1983), Comiso et af. (1984), Svendsen et a1. (1983), Cameron (1983), Owens (19833) and Williams (1986). With adoranced corputer techniques to manipulate satellite data, the amount of retrievable information.has !ncreased. with respect to sea ice studies, the:overall result has been increased knowleaye of sea tce properties.

\subsection{Passive Mitrowave Remote Sensing}

The Dasit-priaciple applied ih passive microwaye remote sensing is the measurement and interpretation of naturalily-em/tted radiation from the earth's surface. Pạssive microwave sensing of sea ice is possible due to the radiometric differences between sea ice and water. This dllows for the distingurshing of ice from water within the sensor's - fielo of view. A discussion of the physics of microwave radiation is beyond the scope of this paper. Ulaby et al. (1981) and Viaby and Garver (1983) discuss the fundanentals of migrowave sensing and radiometry. Only the basic aspects relevant to the sensing of sea ice will De discussed heren

\subsubsection{Microwave Emissivity}

All objects above $0^{\circ} \mathrm{K}$ enit microwave radiation. The term emissivity refers to the ability to emit this radiation, which depends upon 
the composition and the physical structure of the object. Sea ice emissivities vary according to ice type and the frèquency being sensed. Figure 2.1 ll lustrates this variation in emissivity for the major ice types, as reported by Hollinger et al. (1984). The curves were derlved from.multifrequency measurements made at Mould Bay."NWT and in the Eastern Beaufort Sea. When considering Eastern Canadian Seaboard ice conditions, the ice types of interest are new ice, first year ice and ola ice. Emission characteristics of these threg ice types therefore need to be outliged.

When discussing emission from sea ice, the depth below the surface from which the radiation emanates is an important consideration. Zwally et al. (1977) define this as skin depth; the thickness of the top layer frofi which approximately $63 \%$ of the radiation emanates. Since emissivity variation anong sea ice types is related to skin depth (Gloersen et al., 1973), it is a necessapy part of the discussion of emission.characteristics from sea ice typeș:

First year ice, the most prevalent ice type along the East codst, is characterized by the presence, of liquid brine within the ice struciure. Vant et dil. (1978) report salinities near the ice surface ranging from 5 to 16 parts per thousand. Figure 2.22 summarizes, the physical propèrties of first year ice. :The salinity of the ice governs its microwave emission properties. Gloersen. et al. (1973) indicate that the skin tepth of first year ice is 'relatively thin, equalling one'wavelerigth or a fraction there of. For the ESMR and SMMR frequencies concerned $\left(18,19.35^{\circ}\right.$ and $\left.37 \mathrm{GHz}\right)$, this woul a range from $1.7 \mathrm{~cm}$ to 0.81 

The Physical Properties of First Year ice

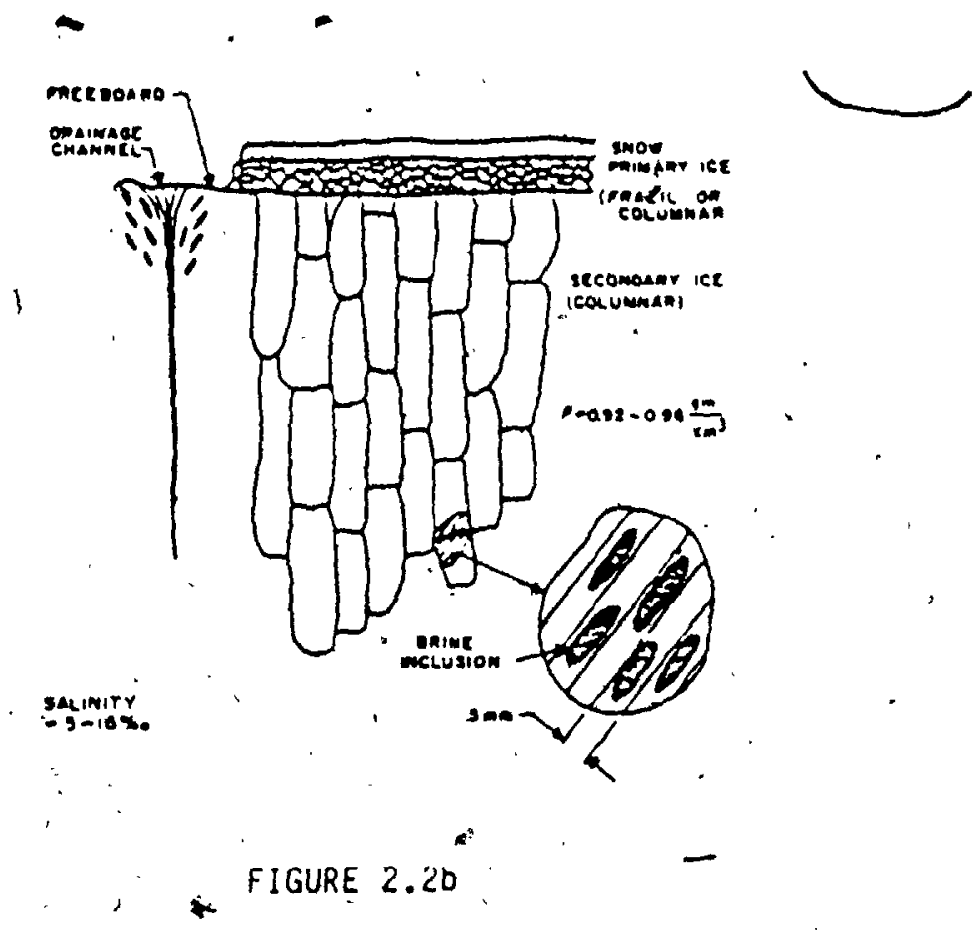

The Physical Properfies of 0ld Ice

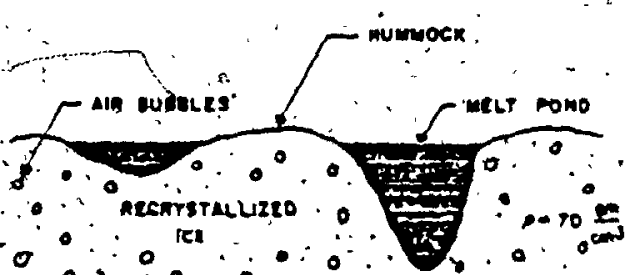

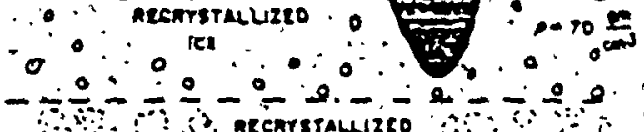
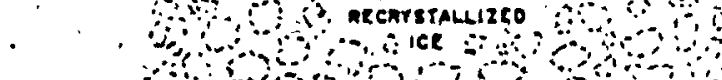

- $\quad$ -

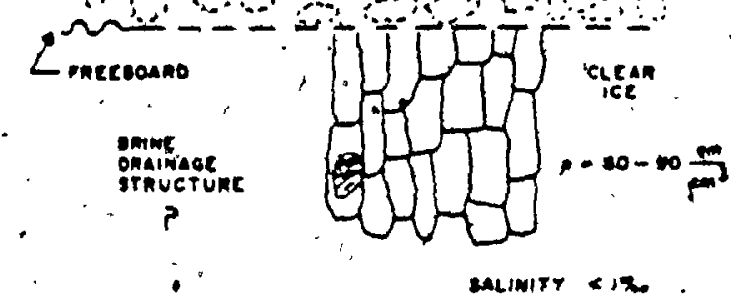

Source: Vant et al. (1978) 
cm: The high salinity of first year ice adso causes it to have a high. entssivity $(\sim 0.95)$, which is almost independeñt of frequency (Hollinger et a 1.; 1984; Rubinstein and Ramseier, 1985) as illustrated in Figure $\because 2.1$.

0ld ice may be found along the Eastern Seaboard in small amounts. This ice type has underyone at least one year's melt and therefore has different physical properties from those of first year ice. Figure 2.20 illustrates this fact. Recent studies, e.g., Bjerkelund et al* (198b), - have disputed the presence of 'recrystal lized ice' layers, and report these layers to consist of snow ice. Vant et al. (1978) report low salinities in multiyear ice, typically less than l part per thousand. near the surface, due to brine drainage during the melting process. "The" low salinity results in a much greater skin depth, in the order of several wavelengths (Gloersen et al., 1973). Therefore a greater. proportion of the microwave radiation emanates from deeper within the ice. The melting process that multiyear ice has undergone results in :the presence of air pockets and other inhomogeneities within the ice (Bjerkelund etal., 1985). These" cause volume scattering of the upwelling radiation to occur, which reduces the anount of energy-emerging from the surface. As a result, the emissivity of old ice is lower than that of first year, as indicated in Figure 2.1. The sensitivity to volume scattefing is directly proportional to the frequency of ine fadiation (Rubinstein ana Ramseier, 1985). Therefore, emissivity decreases with increasing frequency, which is depicted in Figure 2.1 . 
During the ice growth season along the East Coast new ice forms inay be present. New ice, which is generally less than lu cm thick, "is alsQ highly saline, and therefore has a relatively high emissivity, as indicated in Figure 2.1. Initial forms of ice such as frazil and grease ice occur mainly on the water surface and therefore"do not exhibit any appreciable thicknesses. The microwave emission in this case is inainly from the underlying water, resulting in a low emissiy.lty (Ćomiso, 1983). once ice gets into the nilas stage of growth $(5-10 \mathrm{~cm}$ thickness) the emissivity increases and becomes distinguishable from that of water.

The emissivity variation between ice types allows for their. foifferentiation using passive microwave remote sensing. The choice of microwave frequencies is dependent upon the emissivity separation of the ice types being sensed. By examining figure 2.1, it is observed. that the ESMR frequency of $19.35 \mathrm{GHZ}$ and the SMMR frequencies of 18 and 37 GHz have the widest separation between first year and ola ice and open water. Thus it follows that these frequencies are best used for the derivation of ice information.

\subsubsection{Brightness Temperature}

The amount of radiation emitted by a surface is referred to as its brightness temperature $\left(T_{B}\right)$, expressed in the Kelvin (K) unit of temperature. Asurface's $T_{B}$ is a function of emissivity $(\epsilon)$ and physical temperature $\left(T_{S}\right)$, where $T_{B}=\epsilon T_{S}$. The radiation sensed at the satellite height has the added effect of an atmosphere, through which the surface radiation must travel. The radiative transfer equation, 
depicted in Figure 2.3, takes into account the effects of an intervening atmosphere to the sensed $T_{B}$. A cetalled description of each at the components is avallable in Gloersen and Barath (1977) and therefore wit 1 not be repeated here. A suminary of what each of the terms of the equation represents is presented. The first term in the equation represents the contribution of the surface with an incluaed atmospheric correction component. (e-t). The second term is the upwelling radiation observea after reflection at the surface and transinission back through the atmosphere. Fhe thira term represents aownwel ing atmospheric radiation. The fourth term accounts for space radiation reflected back from the surface; which therefore makes two passes through the atmosphere. The atmospheric correction term (e- $\tau$ ) is the most important since it take into account atmospheric attenuation due to the presence of gases and particles.- The polar atmosphere is reliativel y transparent in the frequency range of 19 to $37 \mathrm{GHz}$ fHol linger et di.., 1984), and atmospher of effects can virtually be jynorea. The Eastern CanadraA Seaboara though is located in the mid-latitudes where atmospheric at tenuation is more pronounced. A brlef discussion of the causes of attenuation is therefore necessary in order to understana the derivation of the observed $T_{B^{\circ}}$

The three most influential atmospheric constituents are molecilar oxygen, water vapqur and liquid water oroplets, and their effects are discusseo by wilheit (1978). Attenuation due to liquid water droplets is most important at the microwave frequencies used to derive ice information; name 1 y 18 and $37 \mathrm{GHz}$ (Rudinstein and Ramseier, 1985). As 
FIGURE 2.3

The Radiative Transter Equation

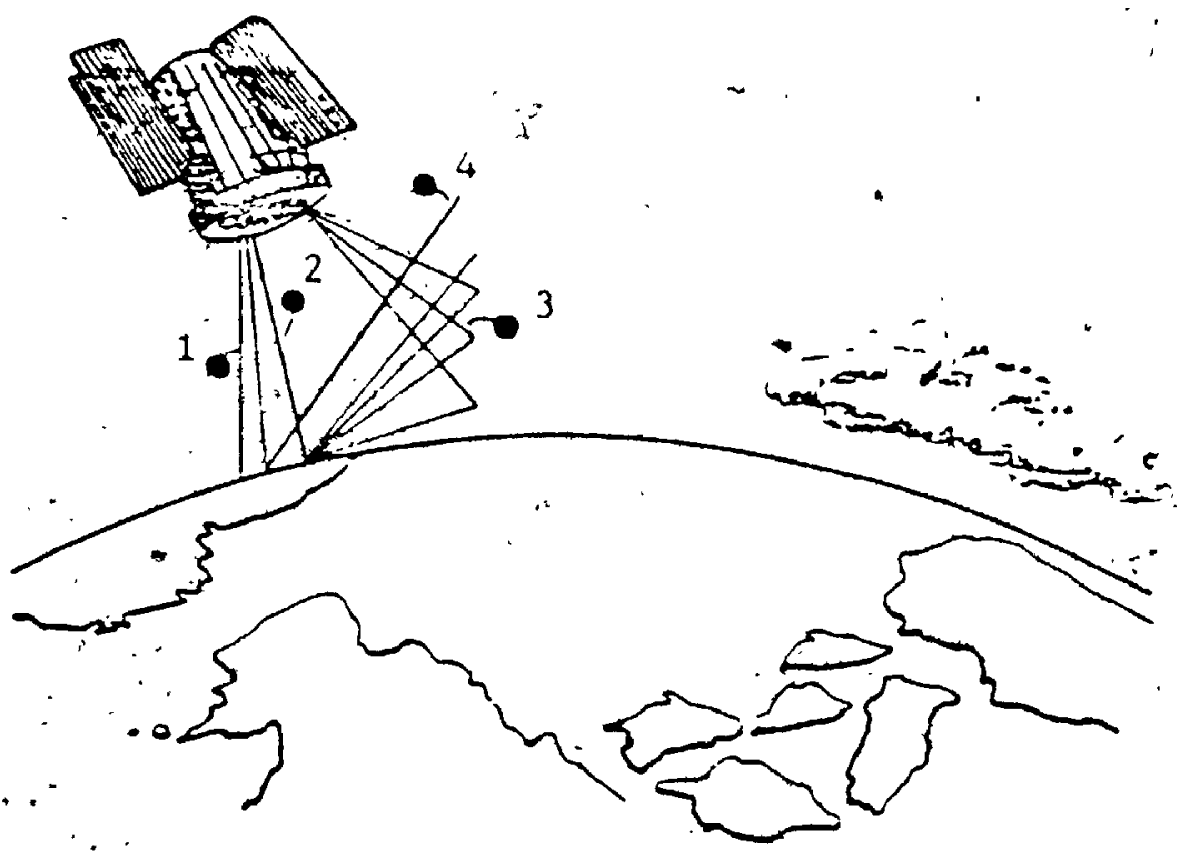

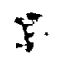

$1:$ SUFFACE EMISSUVITY.

2 a. REZIEOTED DOWNWE'-ING ATMCSFUERIC RACIATICN

3 - UPWELIING ATMOSPHEPIC RADIATICN

4 - REELETIED SFACE RACLATICN

$T_{B}=\epsilon T_{S} e^{-T}+T_{1}+(1-\Xi) T_{2} e^{-T}+(1-s) T_{S P} e^{-2 T}$ $\therefore$ is

Tis: $\Sigma E_{1} T_{S 1}$ SMALL IN PGA

FEGION

Adapted from: Ramseier (1983) 
indicated by wilheit (1978), the absorption coefficient increases with increasing arop size. Precipitating clouas contain the largest arop sizes and therefore provide greater attenuation than either nonprecipitating liquid water or water vapour (Gioersen and Barath, 1977). As the Eastern Canadian Seaboard is subject to frequent cloud cover (both precipitating and non-precipitating) during winter months, therefore liquid water oruplet attenuation must be considered wien deriving ice information from observed T $T_{0}{ }^{\prime} s$. Regionally-specific values for total atmospheric opacity $(\tau)$, applicable to ESMR and SMMR frequencies, "are outlined in Gloersen and Barath:(1977) and Swift et al. $(1985)$.

\section{$2: 3$ Sea Ice and Climate}

\subsubsection{Sea Ice änd Atmospheric Interactions}

The presence of a sea ice cover affects the heat balance of the atmosphere-ocean system by acting às an interface between the two media. crane (198l) indicates that the relative distribution of ice and water surfaces represents the most important influence on atmosphere-surface interactions. Figure 2.4 presents a schematic 111 ustration of the atmósphere-ocean energy balance systen. Heat energy exchange takes place between the ocean and atmosphere. A sea jce cover acts to insulate the ocean by reducing the latent, sensible and long wave heat flux into the atmosphere (Eurupean Space Agency, 1985). Sea ice with its nigh albedo reduces, the amount of solar radiation absorbed at the surface. The amqunt of open water within the ice pack affects the extent 
(

0

$$
\therefore 1
$$

FIGURE 2.4

The Atmosphere-ocean Energy Balance System

20)

J.

5
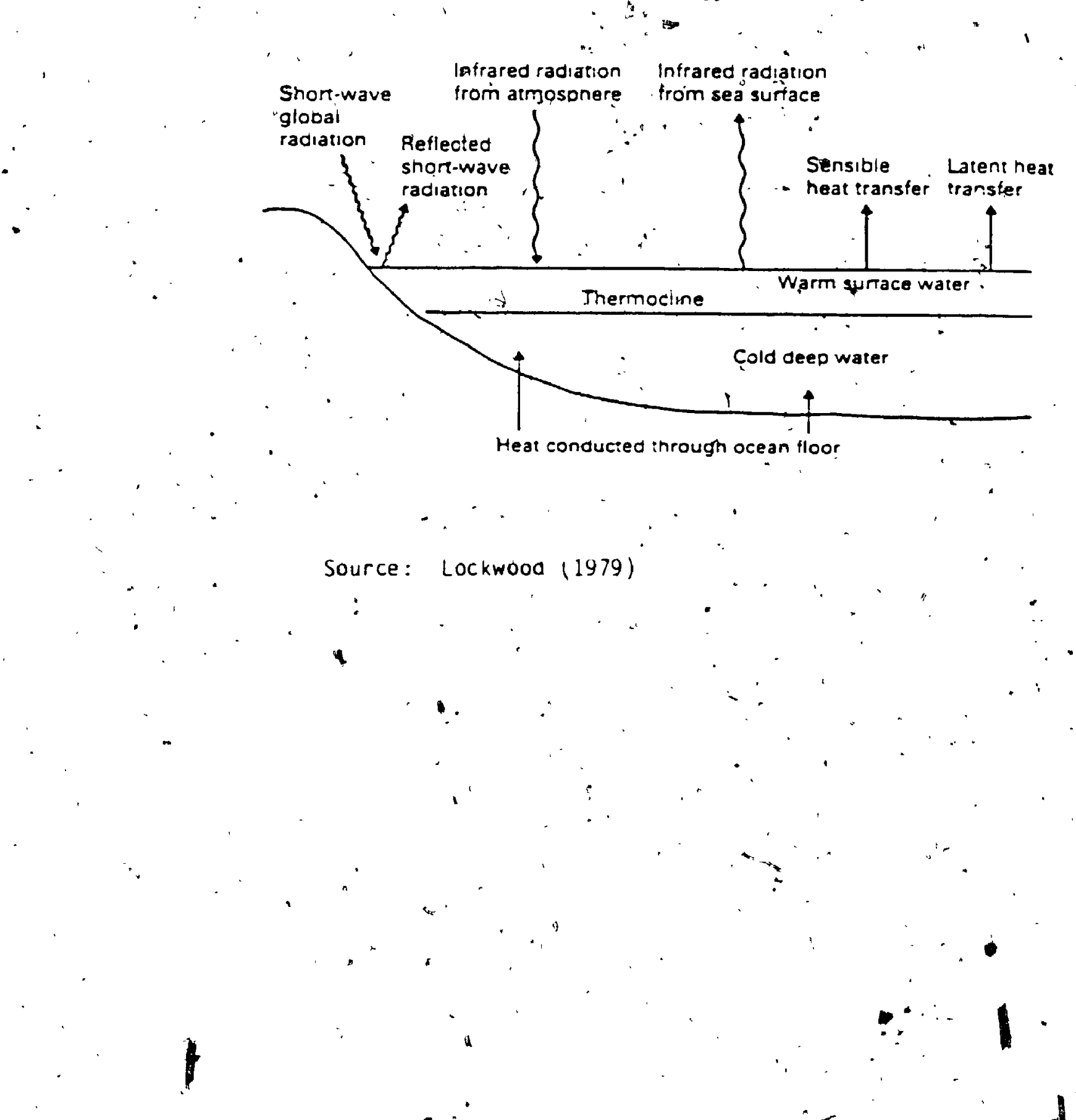
to which sea ice can modify this heat exchange. Thus, ice concentration and sed ice area are important variables in studying this relationship. Feedback mechanisms, as aiscussed by Kelloyg (1y7b) and grepe (1981) are another waylsed ice exgrts an effect on the atmosphere-ocean. system. The positive feedback role of sea ice can de summarized as tollows. A small decrease in temperature increases the extent of the sea ice cover, which results in a higher surface al,bedo, and a further decrease in temperature, which in turn increases the sea ice cover, and so on. Maykut (1978) indicates that sea ice is an umportant comporent in the climatic słstem because it has the potential to amplify simall changes in climate through these feeaback mechanisms. . Thus sea ice variation becomes an important indicator for detecting climatic chanye. 2.3.2 Sea Ice Parameters of Climatic interest

It has been established that sea ice plays an important role in the ylobal climate system:o Interannual variability of sea ice conaitiont as an indicator of climatic change is of principal interest.. Zwally (1984) out I ines the primary sea ice variables of interest as being geographical. extent, concentration? (and ice area), and amount of old ice:

Sea ice models have been developea to simulate the behavior of sea ice in real fife conditions. Sea ice concentration has been usea as a primary variable -ín certain mode, s for input and verification (Zwally, 1984). Atmospheric General Circulation Models (AGCM's), as discussed by Crane (1981) una Al) ison (1982),. simulate atmospheric circulata on over a rong period of time to determine climate, and investigate sensitivity to 
changes in sea ice conditions. Coupled mudels combithe the, 'Pations, and interactions of the ocean and atmosphere to produce a more realistic view of the atmosphere-ocean-ice system. Hibler (lyou) provides an outline of sea ice modelling and indicates that early/results from coupled circulation models are encouraging in determuning the exact role of sea ice in ciimate.

The Eurapean Space Agency (1985) discusses modelling of the polar climate system and points out that the scarcity of polar data makes it difficult to validate these models or choose values for physical parameters. Also outlined are the ice."variables for which data are needed for model verification -- extent, concentiation, thickness and velocity. Information concerning ice extent and concąntration can be derived from passive microwave data. Helocity (derived from changes due to convergence and divergence) can al so be inferred by examining successive days of data...

\subsubsection{Role of Passivè Microwave Data}

Satelifite-borne remote sensors: can provide synoptic information about the polar"regions that would be useful "for the input "and verifi-" cation of sea ice and climate models. Passive microwave sensors can provide valuable and reliable information about seja fce extent and concentration in this effort. Even though the available satellite passive microwave data set is brief and therefore of limited value for climatic research, it has made substantial contributions to the under-' standing of sea ice interannual variation.(NASA, 1984). Al1ison. (1982) 
states that routine monitoring of sea ice from satellites is of "highest priority and that passive microwave imagery. is the optimal. way to.. observe global jce cover.

Studres using passtre microwave satellite data (namely ESMR) have focussed on the relationship between monthly, seasonal and interiannual. variations in sea ice cover" and atmospheric corculation and temperature. Most of these studies have used ESMR (Nimbus-5) data as the basis for investigations. A fewnotable ones will be described here. Crane et d. (1982) used time lapse film and digital ESMR data to relate annual $"$ spatial ant temporal changes in sea ice microwave signatures. in the $\Omega$ Arctic basin to data on atmospheric circulation and surface dir temperature. The focus was on synoptic scale processes. Digital ESMR data was al so used by Crane (1983) to examine atmosphere - sea ice interactions in the Beaufort/Chukchi sea and in the European sector, of the Arctic. Carleton (1984) examined changes in ice extent and concentration for Uctóber 1976 ESMR data in the Western Arctic in relation to synaptic atmospheric events. Cavalieri and Parkinson (1981) and Parkinson and Cavalieri.(1982) related Antarctic ice conditions derived from ESMR to atmospheric circulation. Annual and intérannúl variation in sea ice. conditions were the main parameters of investigation. 

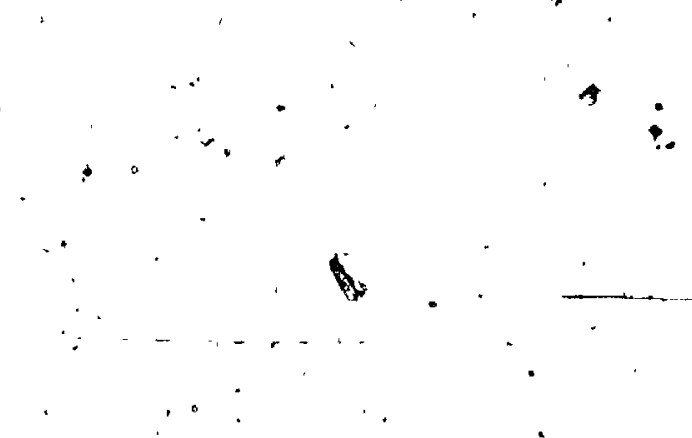

\section{CHAPTER 3}

\section{CHARACTERISTICS UF THE EASTERN CANAUIAN SEABUARU \\ 3.1 Uefinition of the Study Ared}

For the purposes of this study, the Eastern íanadian Seabuard is:

(a)

defined as the coastal waters stretching: from approxinatel y $44^{\circ} \mathrm{N}$ to Is 7U.N. "This plogion includes the ocean water areas known as the liult ut

* Stawrence, the East Newfoundiand waters, the Labrador Sea, anu the $\therefore$

- Davis Strait. Figure 3.1 depicts the baunas of the study area and the location of the subregions (which are the focus of analysis in chapter 5. Section 5.5). "The main codstal meteorological stations of interest are also indicated.

- The fôllowing sections will describe' clinatic and oteanoyraphic characteristics of the Eastern Canadian Seaboard. Tre descriptions wוll "be restricted to the winter time period, which is the season of ice growth.

\subsection{Climate}

\subsubsection{Air Température}

The lowest mean winter temperatures occur in the Decenber to February time period on the Canadian East Coast. Figure 3.2 presents mean and extreme manthly air. température data for various stations and regions along the Eastern Seaboard. The Necember to March period is 


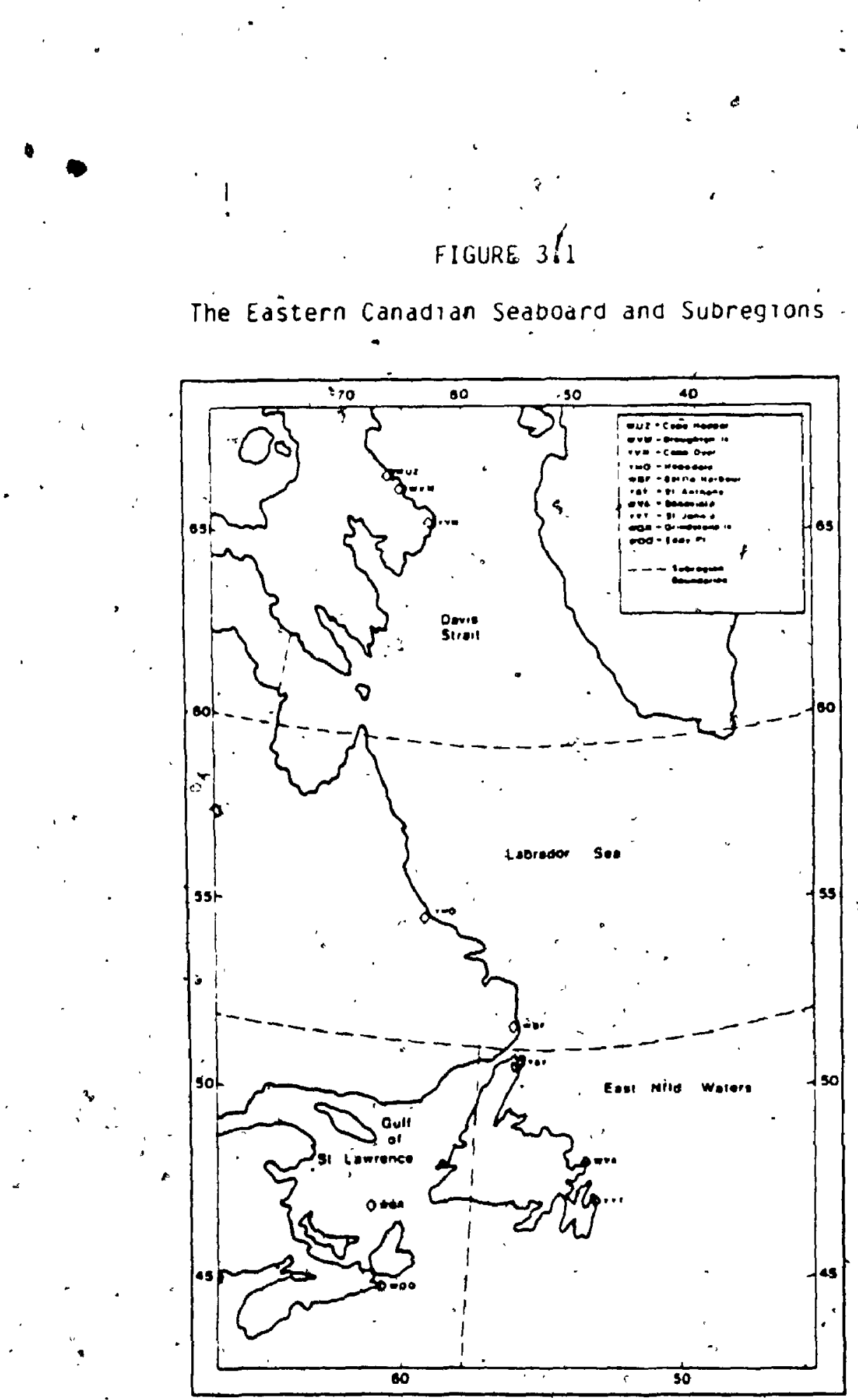

FIGURE $3 / 1$

The Eastern Canadian Seaboara and Subregions 


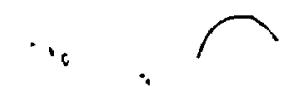

1
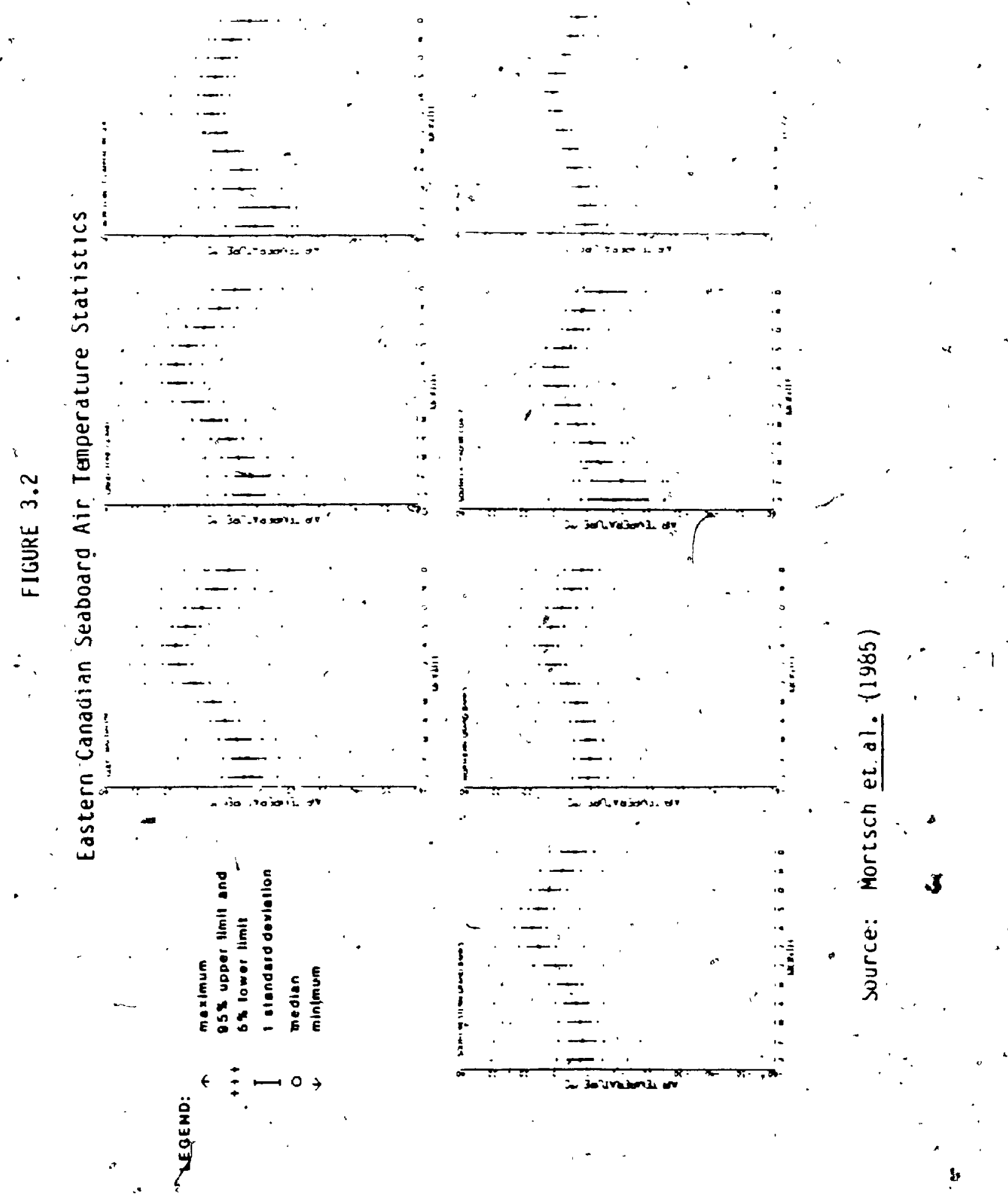
characterizea by belaw $0^{\circ} \mathrm{C}$ air temperatures, which contribute to the growth of sea ice. Markham (1980) indicates'that in the Gulf of $5 t$. Lawrence and Newtounalana waters areas the inean temperatures during winter do not fall very far below the freezing point. The result is that abnormally cold and mila winters can have greater effect on the degree of ice growth-in this region, than in more northern regions.

The accumulation of freezing degree days (FUU) can be used as an indicatar of the coldness of a winter. A freezing degree-day is defined as the departule of the daliy mean alr temperature by jone degree below. the freezing point (Markham, 1980). Two days with daily means of $-10^{\circ} \dot{C}$ would correspiona to an accummulation of 20 freezing degree days. Average FDD accumulations to the end of February. for the following meteorological stations indicate the range for the Eastern Canadian Seaboard:" St. John's = 362.6, Hopedale - 1413.3, and Cape Hooper 2969.3 (Environment Canada, ig82).

\subsubsection{Air Pressure}

During the winter months; the East' Coast is under the influence of. the Icelandic Low, normally located between Icelana and Greenland. Bursey et al. (1977) report surface pressures of less than $100 \mathrm{kPa}$ for this low during the month of January. Figure 3.3 exhibits the surface pressure disţribution for the month of January, typical of winter condi- tions. As with all laws in the Northern Hemisphere, circulation is in a counter-clockwise direction around the fow. The prevailing wind airection is thus northwesterly for the East coast region. "In general, areas 
•

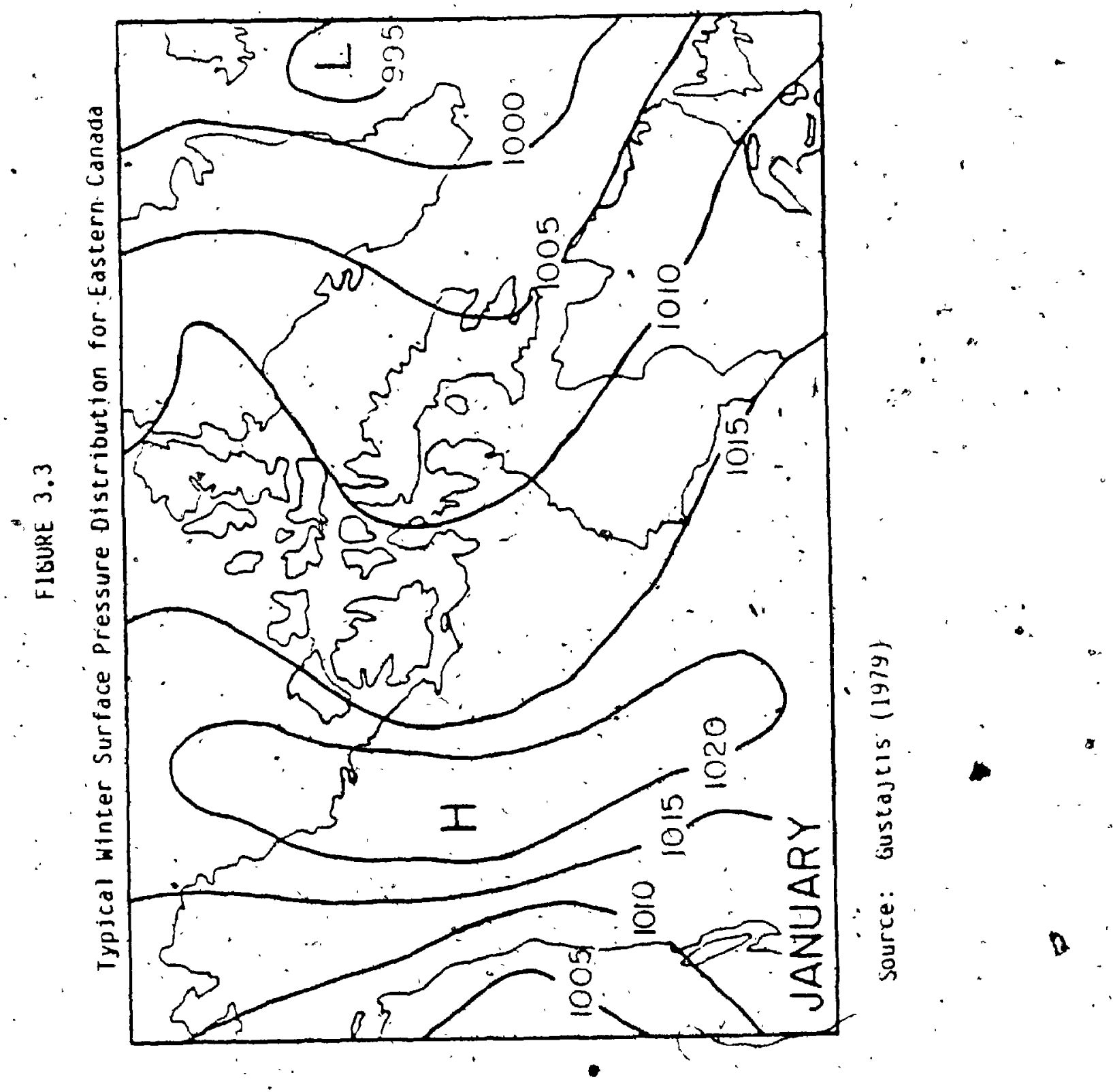


of low pressure are characterized by stormy and unsettled weather, and the East Coast is no exception. During the winter months (January to March), over $50 \%$ of the time, the East coast is totally obscured by cloud cover (Gustajtis, 1979).

The position of the Icelandic Low can vary from year to year. Bursey et al. (1977) report that the centre of this low ranged from near Spitsbergen (in the Greenland Sea) to Newfoundland during the 1970's. This variability can affect the circulation pattern governing the. - Eastern region, which can in turn influence the sea ice regime.

\section{2 .3 winds}

- The winter pressure pattern aver the East Coast results in a prevailing northwesterly wind flow. Figure 3.4 illustrates the typical winter distribution of wind velocities along the East Coast, The. strongest winds are encountered in the winter months. Bursey et al. (1977) report that during the months of December to March, over $50 \%$ of the wind speed observations are 22 knots $(-40 \mathrm{~km} / \mathrm{hr})$ and greater. Surface winds influence the location and distribution of ice (Markhan, 1980), and increased wind strength augments this influence.

\subsection{Oceanography}

Gustajtis (1979) has described the oceanographic chàracteristics of the Eastern Canadian Seaboard, with particular reference to the Labrador sea. The relevant aspects with respect to the sea ice regine, are sumarized here. 
Typical winter East Coast wind Velocities

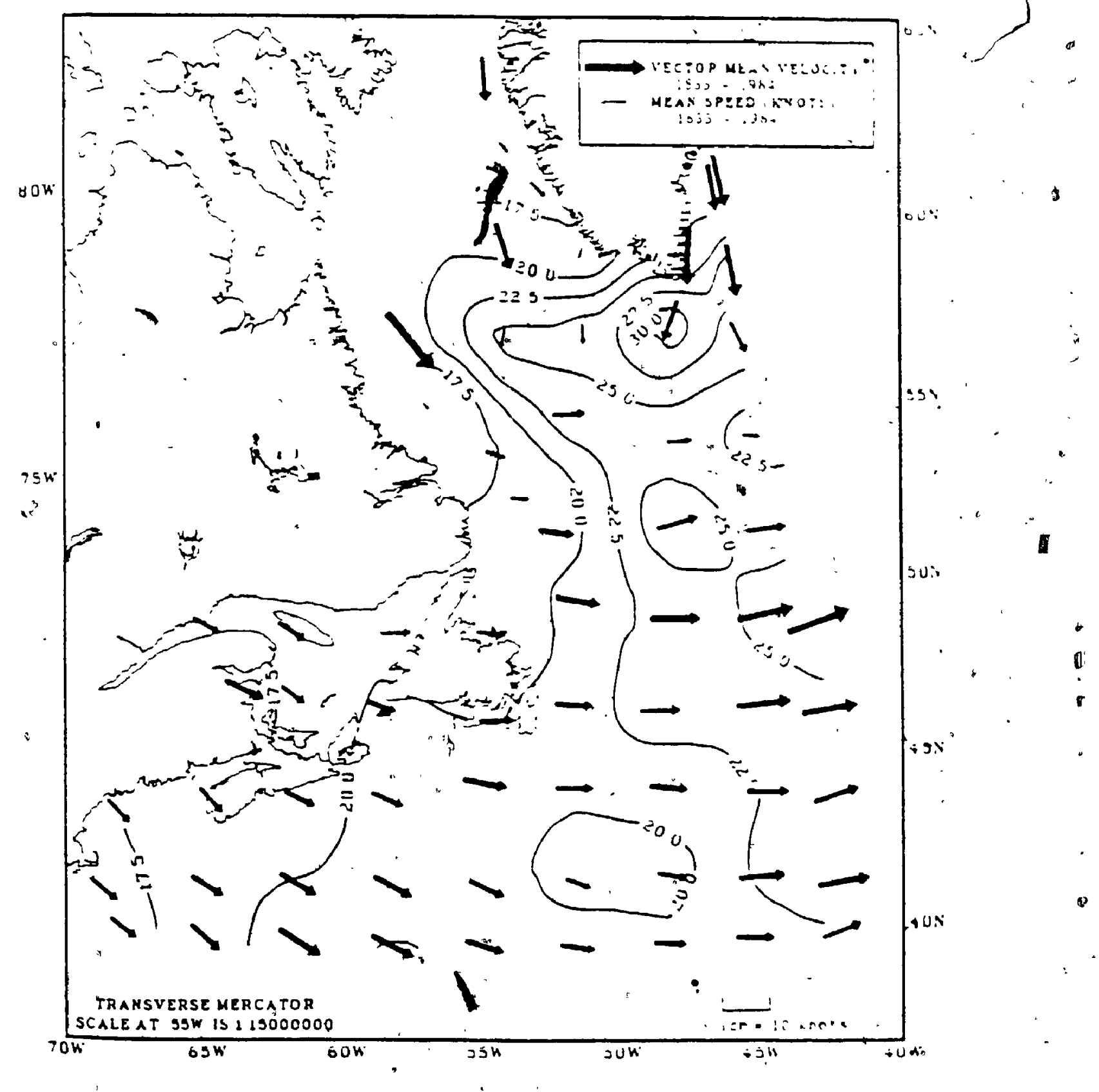

Source: Mortsch et al. (198b) 


\section{3 .1 Currents}

The Labrador Current is the major feature of the ocean circulation alony the East Coast. As i liustrateo in Figure 3.5, the origin of the current is in the of $60^{\circ} \mathrm{N}$, where the west Greenland Current offshoot and the Baffin Island, or Canadian, Current converge. .

The Wiest Greenlana Current, which is the inajor contributor to the Labrador Current (Lazler, 1980'), is relatively warm and remains ice-free as far north as $67^{\circ} \mathrm{N}$, North of $60^{\circ} \mathrm{N}$ a oranch of this current flows westwara, and becomes part of the Labrador Current. The Canadian Current, consisting of cola Arctic water, flows soùthward along the eastern Baffin Islada coast. At Hudson Strait one arm flows west and eventually joins the outflowhy current from the stralt. The other arm flows south across the strajt to form the Labrador current. Thus the Labrador Current' receives its energy from the flows of the two currents described ábove and the outflow from Hudoron strait.

- The Labrador Current is aivided into two streams. The inshore stream is confined to the continental shelf and contains. cold polar water. The off'shore stream is much warmer with its origun from the west Greenlaña Curfent. Steun (1982) refers to these two strraams as the polar component and the Irminger Current, respectively. The Labrador Curient travels south along the Labrador and Newfoundland coasts, where * it alvigesinto two brarkihes in the Grand Banks region. 'Lazier (1980) reports that surface current velocities for the main Labrador Current range from 35 to $40 \mathrm{~cm} / \mathrm{s}$.

In the Gulf of St. Lawrence the main flaw of water is froin the St. 
FIGURE 3.5

Major Ocean Currents Alony the Eastern Camadian Sedoodrd

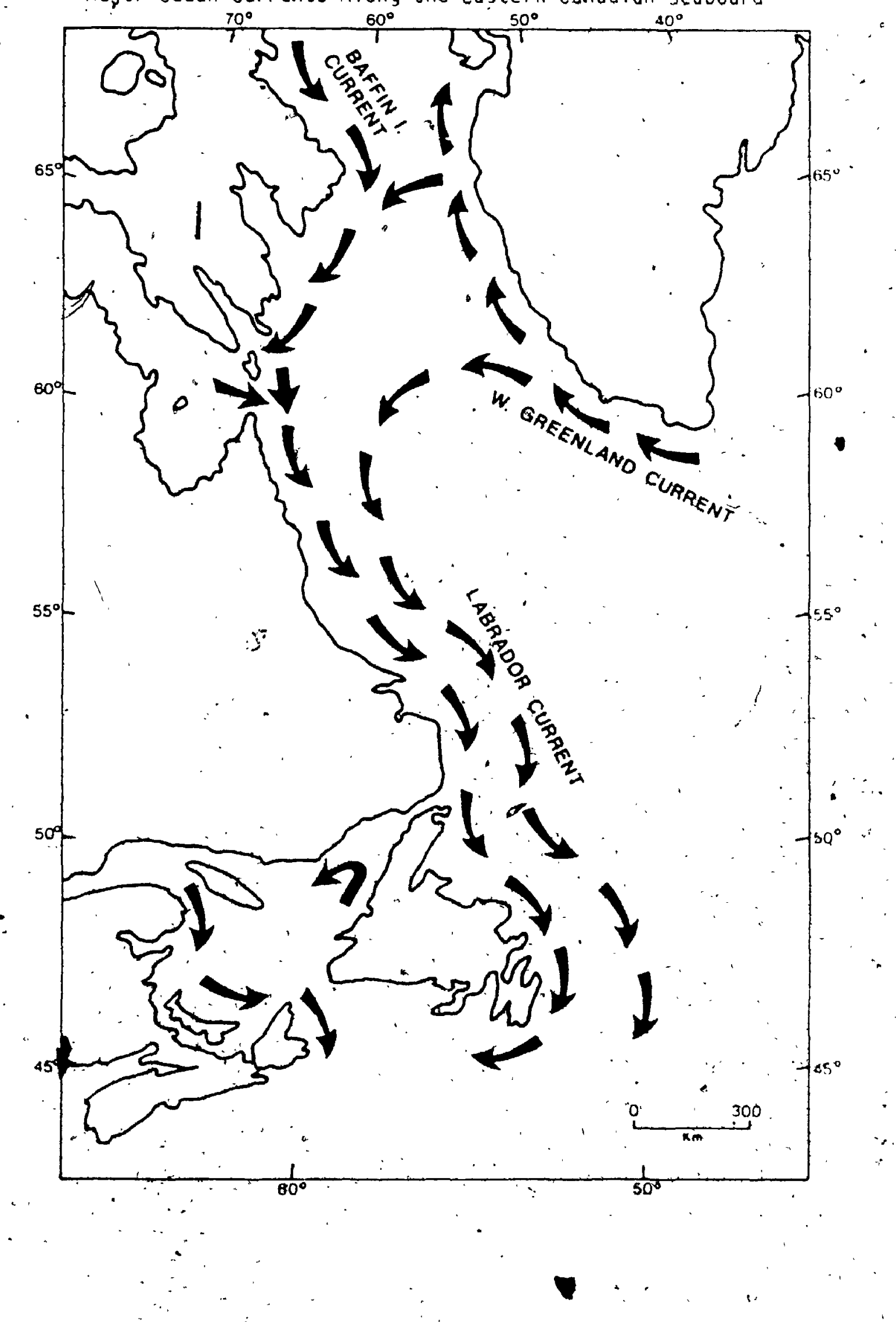


Lawrence River sótheasiwara to the cabot Stralt (Atmospheric Environment Service, 1982). The laspe Current and the Cape Breton Current forin the outwaraflow of water from the Gudf. Two inwara-flowing currents travel up the western coast of Newtounalariu and alung the suuthern coast of Anticostr is land, respectively.

\section{3 .2 sed Surface Temperature}

Typocal winter sea surface temperaturés are portrayed in figure 3.6. The isothenns. represent mean conditions for the time period 1855 to 1984, derived from data collected by sbips-of-oppörtunity (Mortsch et (1). 1985$)$.

\subsection{Séà lce Regimé.}

Sea ice begins forming in the Eastern Canadian Seaboard region as sop̣ à temperatures fall below freezing. Formation starts in the northernmost region of the study ared first, with ice spreading through Davis serat during the month of November. During Deceinber the ice spreads rapialy down the Labrador Coast toreactione strat of Bel le Is le by the end of thamonth. The monttis of januaryand fiebruary are characterized by southward growt in the East Newfoundland Waters and Gulf of St Lawrence regions. Seawara expansion continues in all other regrons. Maxinum ice extent is usually attaned in the late february to inid-Marchperrod, depending upon the severity of the winter. In iate March the ice begins its retreat northward, a trend which cortinues until the beginning of August, when the Eastern Cianadian Seaboard is 


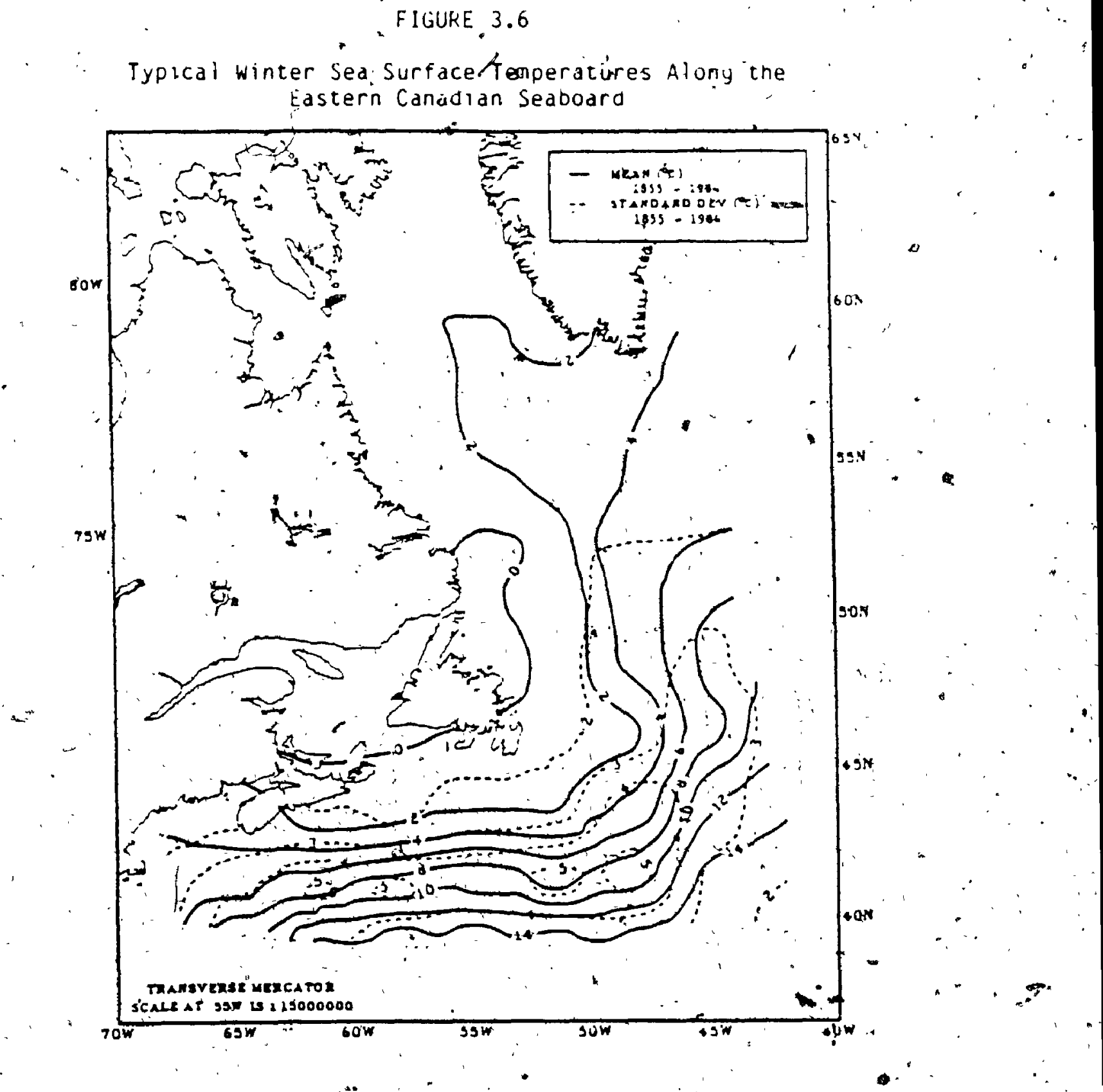

Source: Mortsch et al. (1985) 
virtually ice-free ayain.

\section{4 .1 Ice Characteristics}

Sea ice alony the Eastern Seadoard is prinarily forst year ice. Level pack. içe can reach thicknesses up to $150 \mathrm{~cm}$ (Atmospheric Environ-

$\because \quad$ ment service, $198 \ddot{2})$, al though rigyiny may create greater. thicknesses. The drift of ice from northern regions accounts. for large thicknesses. Generally ice thickinesses increase from south to north in the. study area. due to the longer ice growth seasons. The continual movement. of the pack, "aue to winas ana currents, causes ice to be broken and - rejoined severil tines, resulting in pieces af ivarying sizes and thicknesses to be present (Skidmore, lyg). Di \$ergence and compression take place in response to wind speed and changes in directlon. Divergence, due to offshore blowrng winas, creates opegyater reads between ice f́loes, while compression, due to onshore blowing "winds, solidifies he pack:

$\because$ Throughout the wintẹr., new ice forms are present, especially *in the ige margin region. New ice, which is generally less than $10 \mathrm{~cm}$ thick.

$\because$ (Atmospheric Environment Service, 1980), takes the form of grease ice or - nillas. Thos stage of ice development also has a hugh salinity. New ice can also form within the pack, between jce fives; after divergence has taken place.

old ice, which has survived more than one year's melt, may be present within the East coast paçk. The origin of this ice is the more. inorthern Arctic Markham (1980) estimates the amount of old ice 2 
present to be approximately 10\% of the total pack.' Uuring colder than usual sumers, ice may survive melt periods in northern fegions such as Baffin Bay and Foxe Basin. Floes of old ice can therefore arift down the Eastern Canadian Seaboard and become mixed with the pack, ice of the following winter. The Atmospheric Environment Service (1982) reports. that thicknesses of old ice along the Labrador Coast have been medsured. up tó $210 \mathrm{~cm}$.

$\because$

\subsubsection{Factors Determining Ice Extent}

- The maximum extent to which the sea ice cover yrows each year alony the Eastern Seaboard,is a function of several factors, some of which are - interdependent. Marknam (1976) discusses the variability of ice seasons along the Canadian Eastern Seaboard and indicates that the key factors which affect the severity of the seasons are air temperature, winds and water currents.

Below-freezing air. temperatures initiate the growth of ice, and thie length of 'tjme which they stay below $0^{\circ} \mathrm{C}$. ensures. the continued production of new jce and $a$ lows extent to increase. The windflow controls the movement. "of the ice and determines how dispersed or compresset the ice cover will be. The relative coldness or milanes sof the wind is related to he çaracteristics of-its source (e.g., Arctic). In this way, air temperature and wind are interdependent.

Ocear curgents, particularly the-Labrador current, influence the movement of the sea fce.cover, down the East coast, but their soa sufface temperatures determine fomation "f ce. "The tabrador. Current fan vary". 
ith temperature, which exerts an effect on ice growtit in the region: Markham (1976) reports that in the early part of 1973 the Labrador Current was abnormally cold, which permitted more ice to form, and earlier than usual, along the Labrador-Newfoundland coast. Schell et al. $(1 \dot{9} 75 j)$ discuss the effect of increased water volume transport from the west Greeniand Current, which would result in higher Labrador Current water temperatures. This would inhibit the growth of ice and limit its spatial extent.

Ätmospheric circulation also infiluences ice extent along the Eastern Seaboara. Barry $\left(1980^{\circ}\right)$ inaicates that the overal l pattern of ick extent in the Northern Hemisphere ${ }^{i}$ is strongly indenced by interactive oceanic and atmospheric circulations. The atmospheric pressure pattern control's the. flow of air within the region, thus affecting the winds and air temperatures.

The position of the Icelaric Low in winter controls the atmos"pheric circulation in the Eastern Seaboard region: The interannual yariability of the Low's position has been noted by several authors (Markham, 1976; Bursey et ál., 1977; Johnson; 1980) with corresponding effects on ice extent. Markham. (1976) reports on an analysis of pressure charts for light and heavy ice years, 1960 and 1973 respec-. tively. In 1960 the Icelandic Low was displaced south, resulting in a restricted Eastern Seaboard ice cover due to a northeasterly air flow. . In 1973 the position of the Low provided a cold northwesterly flow from the Arctic, which resulted in an extensive ice cover. Johnson (1980) indicates that the displacement of the Icelandic low to the northeast 


\section{t}

results in greater than nurmal ice extent in the Arctic. From dnalyses of 25 years of pressure data, Jonnson concludes that reglond l extremes In sea ice are associated with the intensification of the closest indjur low pressure centers and troughs.
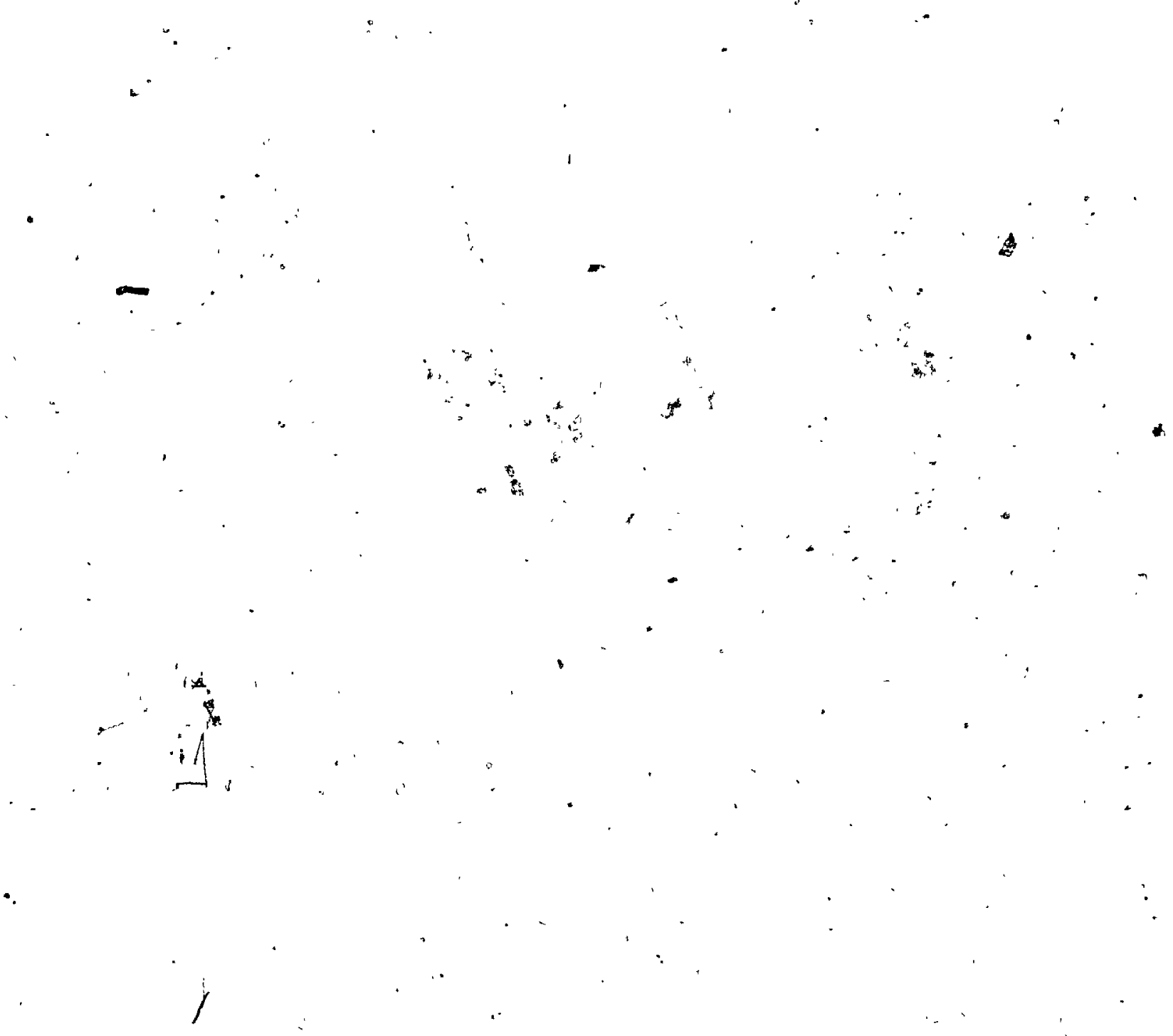

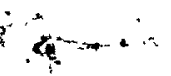


CHAPTEK 4

ANALYSIS UF INTERANNUAL SEA ICE VARIATIUN

\subsection{Format of the Passive Microwave Uata}

The Nimbus-5 ESMR and Nringus-7 SMMR aata are stored on computer tapes: The basic format of these tapes consists of brightness temperatures $\left(T_{B}^{\prime} s\right)$ stored for each beam position: The simMR liape product used in the Eastern Seabgard analysis is the CELL-ALL tape, which contains vertical and horizontal polarization. $T_{B}$ 's and seasonal geographic filters for each of the five channels, grouped into combinations of cè l ls and pangs equal ling $780 \mathrm{~km}^{2}$ (Gloersen and Hardis, 1978). Location coordinates" are ǵ archived at the National Space Science Data Center (NSSDC) at the NASA Goddard Space flight Centẹr, Greenbelt, Maryland:" A Canadian archive of tapes exists at Ice Resear.ch and Development (AES), York University, North York, Ontario.

The set of ESMR and SMMR data tapes that were available for this analysis unfortunately inçlude a data gap covering the 1978 winter season. U.S. Navy ice charts, which are compiled from ESMR data (Eppler, 1983), became the source of 1978 ice information for the interannual variation analysis. The U.S. Navy utilizes data processed from the National OCeanic Data Distribution System (NODDS). Comparisons between NOUDS data and data processed Dy"NASA have shown that there is 
no significant difference petween the two products (w1) 11 iams, 1980$).$

4.2 Sed Ice Alyorithins

In order to derive sea ice information frum the archived $T_{b}$ data, computer-based algurithms must be applied to the ta. Sea ice concentration is the desired parameter, which refers to the percentaye ut an ocean area covered by ice (2waljy, 1984). For the Eastern Canadian Seaboardanalysis, sea ice algorithins specific to ESMR and SMMk were. utilizéd in order to derive ice concentrations and ice, edye positions. Constants usea in these algorithms were al so derived specific to the East Codst region: The: algorithms used are discussed in the folluwny sections.

\subsubsection{Simple Linear Àlgorithm}

Since the ESMR is a single frequency sensor, a simple linear algorithm is used to derive 'ice concentration. The basic operation of the a lgorithm ínvolves deriving a percentage value for ice concentration from an observed $T_{B}$ through a linear interpolation between characteristic radiances $\left(T_{B}: s\right)$ of open water (U\% jcet and luot sea ice cover (Gloersen et al., i974). Figure 4.1 expresses this algorithm yraphlcally. Using the linear relationship assumed by this alyorithin, an area of $50 \%$ ice cover would have an observed $T_{B}$ halfway between that of open ocean and fully consolidated ice.' For the Eastern Seaboard analysis,

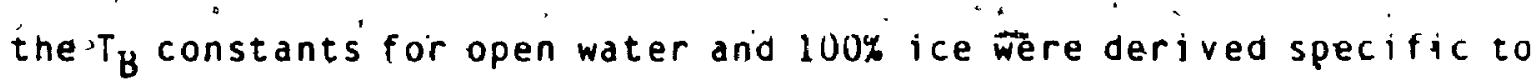
the East Cóast region. As indicated in Figure 4.1, the characteristic 
FIGURE 4.1

The Simple Linear Algorithm

I

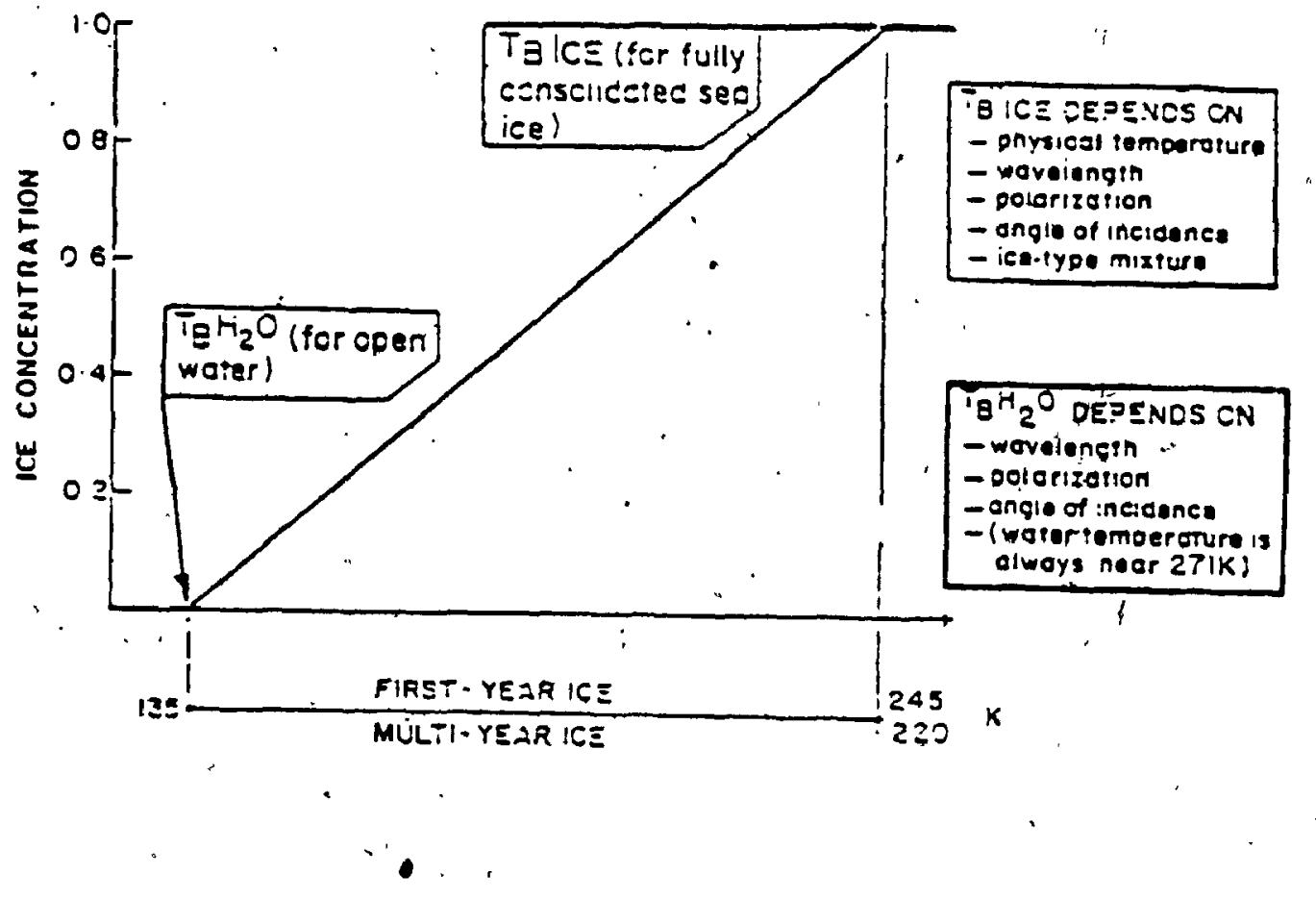

Source: Ramseier (1983) 
$T_{B}$ for open water at $19.34 \mathrm{GHz}$ is $\sim 135 \mathrm{~K}$ while first year ice is $\sim 235 \mathrm{~K}$. The vatue produced using the simple alyorithm. is a total, ice concentration, ineaning that ice type (1.e., flast year or old) is not dif - . ferentiated. The single frequency and polarization nature of the. ESMR data prevents arect separation of ice type, al though Gloersen et al. (1978) report that in certain seasons and locations relative amounts of first year and old ice can be estinated. Since first year icerts the predominant ice type on the East Coast; this limitation of the alyorithin is not significant. Thus, it can be assumed that trie total ice confentration value approximates a concentration of first year ice.

- Another limitation to the algorithm concerns the effect of ocean roughness. 'Wind biowing, across the ocean surface creates roughness and foam. Wilheit (1978) discusses the effects of a rough ocean state on microwave sensing. Generally, roughness and form cover increase the ocean surface emissivity, and hence the observed $T_{B}$ as fllustrated in Figure 4.2. When this higher than normal observed $T_{B}$ is used as input into the simple linear algortthm a false ice-concentration wit d be produced; thus deceptively implying the presence of ice in open ocear. For example, Comiso and Zwa) lyu(1984) state that the. T ${ }_{B}$ of areas with ice concentrations" $25 \%$ and lower often equals those of ice-free regions, where extreme surface conditions (e.g., fodp and roughness) are present. Since storm activity, which creates rough ocean states, is a common feature of winters on the Eàstern canadian Seaboard, careful interpretation must be made of the ice concentrations produced from passive microwave data. Owens and Ramseier (1984) report, from an analysis of East. 
FIGURE 4.2

The Increase in $T_{B}$ at $19.35 \mathrm{CHz}$ Caused by wind Speed uver an Ocean Surface

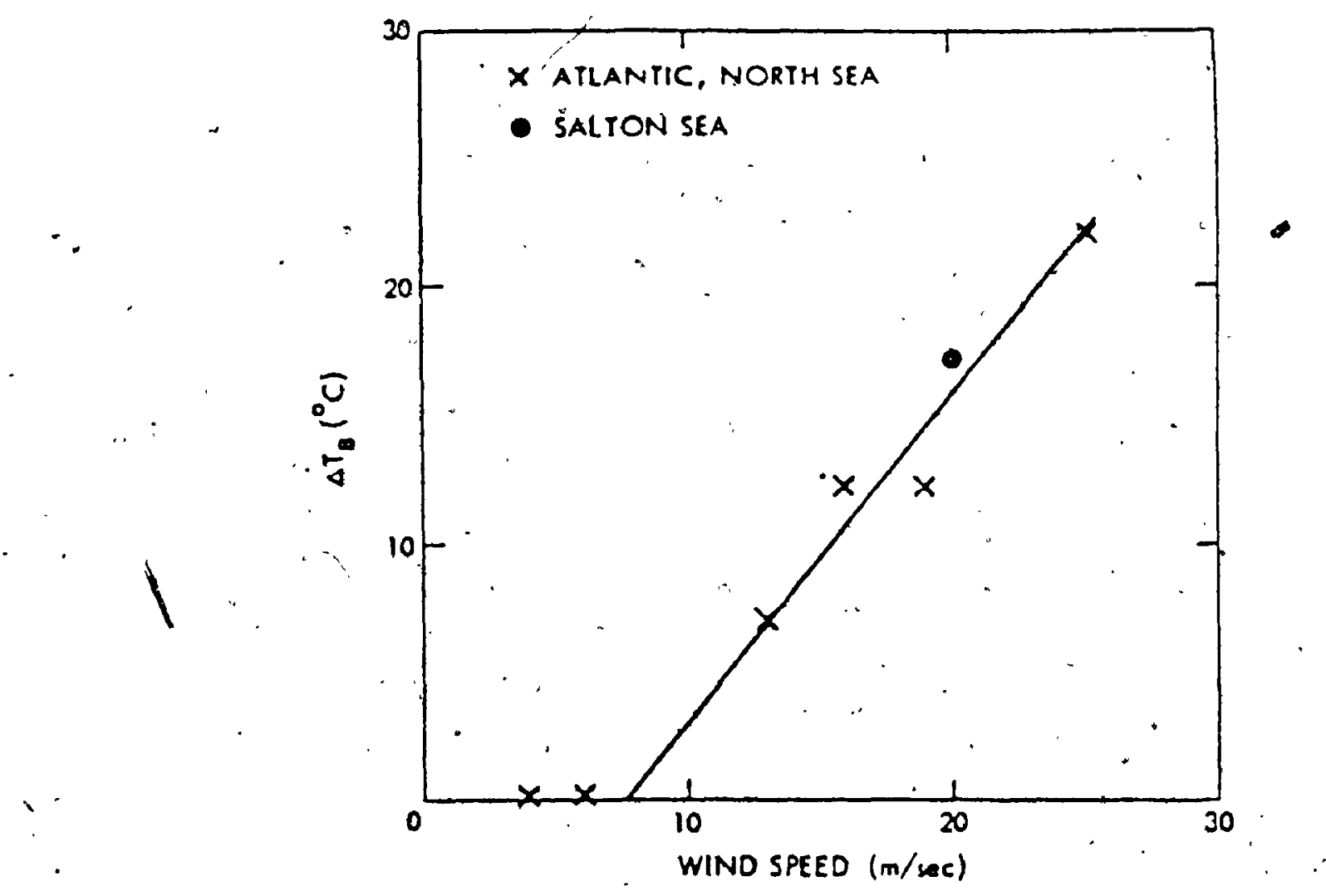

Source: wilheit (1978) 
Coast ESMk ice maps, that the erroneous ice concentrations produceu due to storm activity average around 10\%. Based on knowledge and experience in the East Coast region, a person can rgnore erroneous lice concentrations. Unfortunately, with the single frequency data it is inpossiole to remove the rough ocean effect from the $T_{B}$ data. As discussed by Wilneit (1978), multifrequency data is needed to overcone this limidtion, and has been 'successfully done with the SMMk data (Rubinstern and Rarnseier, 1985; Rubinstein et.al., 1985).

\subsubsection{AES/Ph.D. Algorithm}

The AES/Ph.D. algorithm was developed and tested specifically with Nimbus-7 SMMR data.' Using two of the SMMR frequencies, 18 and $37 \mathrm{CHz}$; the capability is present to differentiate between two ice types, nanaly first year arid old ice. Thus, the algorithm produces ice concentration values for first year ice and old ice, as well as total ice values (Rubinstein et al., 1985). Rubinstein et al. (1985) and Rubinstein. ano Ramseier (1985) outline the developnient of this algorithm. The basic feature of the modet is multi-step filtering, which removes the effects of cloud, wind and precipitation. A flowchart representation of this aspect is presented in Figure 4.3. The dim of the filtering technique is to prevent ice edge distortions due to 'rough ocean or weather; a I imitation that affected the single frequency ESMR data. The algorithm uses regionally-specific inputs (constants). Thus for the Eastern Sedboard analysis constants were utilized specific to the East codast region and its ice canditions. 

The operation of this algorithin is computer-based. At each sinMk $\therefore$ cell location the $T_{B}$ is tested in order to deterinine it the source ut the microwave emission is from an ice-covered area or due to rough sed or weather conditions. The filters then remove any atmospheric or wind effects, with the final output being total ice concentration and the ice type fractions, as illustrated in Figure 4.3. .

The AES/Ph.D. alyorithin has been tested operationally for selected regions, the Eastern Canadian Seaboard being ane ot thell. Moreau et al. 1985) report on the valudation of algoritinm results for East coast ice conditions against Atmospheric Environment. Service ice charts. Prelıminary results indicate ice concentration agreement to $\pm 10 \%$ and rce edge agreement to $\pm 15 \mathrm{~km}$.

\section{3 - Oisplay of the Ice Concentration Data}

The ice concentrations produced lising the previous!y described algorithms can be contoured and mapped onto a geography overlay usiny specialized computer software (Thirkettle, 1985). The presentation of the ige information in map format allows a user to visually examine the spatial extent of the sed ice cover and the pattern of ice concentration:

The system involved in processing the passive microwave data is described in Thirkettle (1985), and summarised here. Before'the TB's are converted into ice concentrations, the data is remaped on to a subset.of the Canadian Meteorological Eentre (CMC) $381 \mathrm{~km}$ square grid, using a weighted averaging technique. For the Eastern canadian Seaboard 
analysis a, $1 / 10$ CMC grid was employed, where each grid square measures $38.1 \times 38.1 \mathrm{~km}$. This is slightly larger than.the size of one ESMR or" SMMK footprint. The next stage involves applying the ice concentration algorithim to the reduced data set. Contouring software allows the ice concentration data to be summarized accoraing to specific percentage concentration levels. For the East Coast analysis the levels $10 \%, 15 \%$, $35 \%, 65 \%, 85 \%$ and $99 \%$ were utrlized. Mapping routines then position the Ice information onto the physical map at the specified projection and scale. For the East Coast analysis:a $1: 5,000,000$ polar stereographic map was used. Figure 4.4 presents an example of the format of the map (at a reduced scale) used in this analysis.

\subsection{Analysis Methodology for Interannual Vartation \\ 4:4.1 Dates of Maximum Ice Extent}

The first stage in the analysis of interannual variation in maximum ice extent involved determfning approximate dates of maximum.extent for each year from 1973 to 1985." Archived ice charts at the Ice Climatology and Applicaffions Division of the Atmospheric Environment Service provided the source of this information. By examining the charts visually for each ice season, the time period of maximum spatial extent for, the entire study area was narrowed down. Using these dates as a guide, passive microware data covering a period of several weeks were processed.in order to ensure coverage of maximum extent. Because the Nimbus-? SMMR only operates every second day and due to its orbital configuration; 3 days of data were needed in order to get completé 
Example of Map Portraying Passive Microwave Derived Ice Concentrations

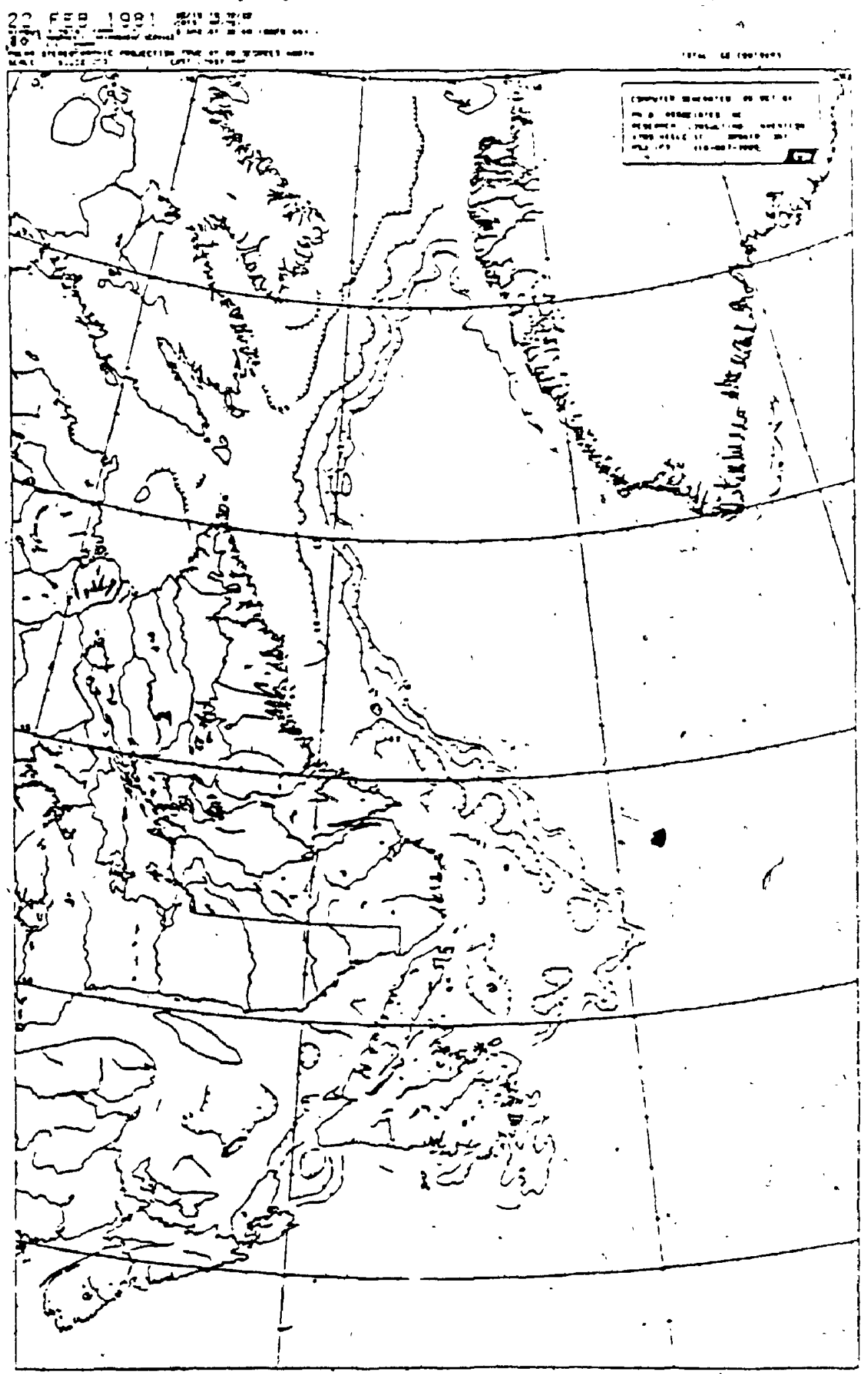


coverage of the Eastern Canadian Seaboard. The resulting ice map was therefore an average of 3 SMMR days, which approximately corresponds to a weekly ( o days) average. Since complete coverage is available with one day of ESMR data, a single daily averaye for each week in the specified time period was utilized.

For each year in the time series, the ice maps were overlala in. order to determine which map contained the maximum spatial extent of ice. Appendix A.l contains, the maps expressing the maximum ice extent for each year, 1973 to 1985. The 15\% concentration contour l ine was used to represent the ice édge position. A summary óverlay was produced containing the maximum ice edge location for each year from 1973 to 1985, which is a total of 13 ice edges. Visual examination of this overlay yielded information on which areas of the Eastern Canadian Seaboard experienced the most variation during the 13-year period. The East Newfound and Waters and Davi.s Strait, regions are the most variable in terins of maximum ice extent, where the difference between extrefie maximum positions of the ice edge range from 500 to $600 \mathrm{~km}$, while variation along the Labrador Coast is not" as great, ranging from 150-300 $\mathrm{km}$. The Gulf of st. Lawrence exhibits variation of the order of $200, \mathrm{~km}$. Thesé męasurements were ubtained directly from the overlay, main ly parallel to lines of latitude, and along the main axes of ice growth. Figure 4.5 exhibits extreme positions of maximum ice extent from 1973 to 1985. Each line is a composite of extreme extents for each region, therefore they do not represent one single ice season. Although, the - 
FIGURE 4.5

Extremes in Maxinium Ice Extent Position (1973-1985)

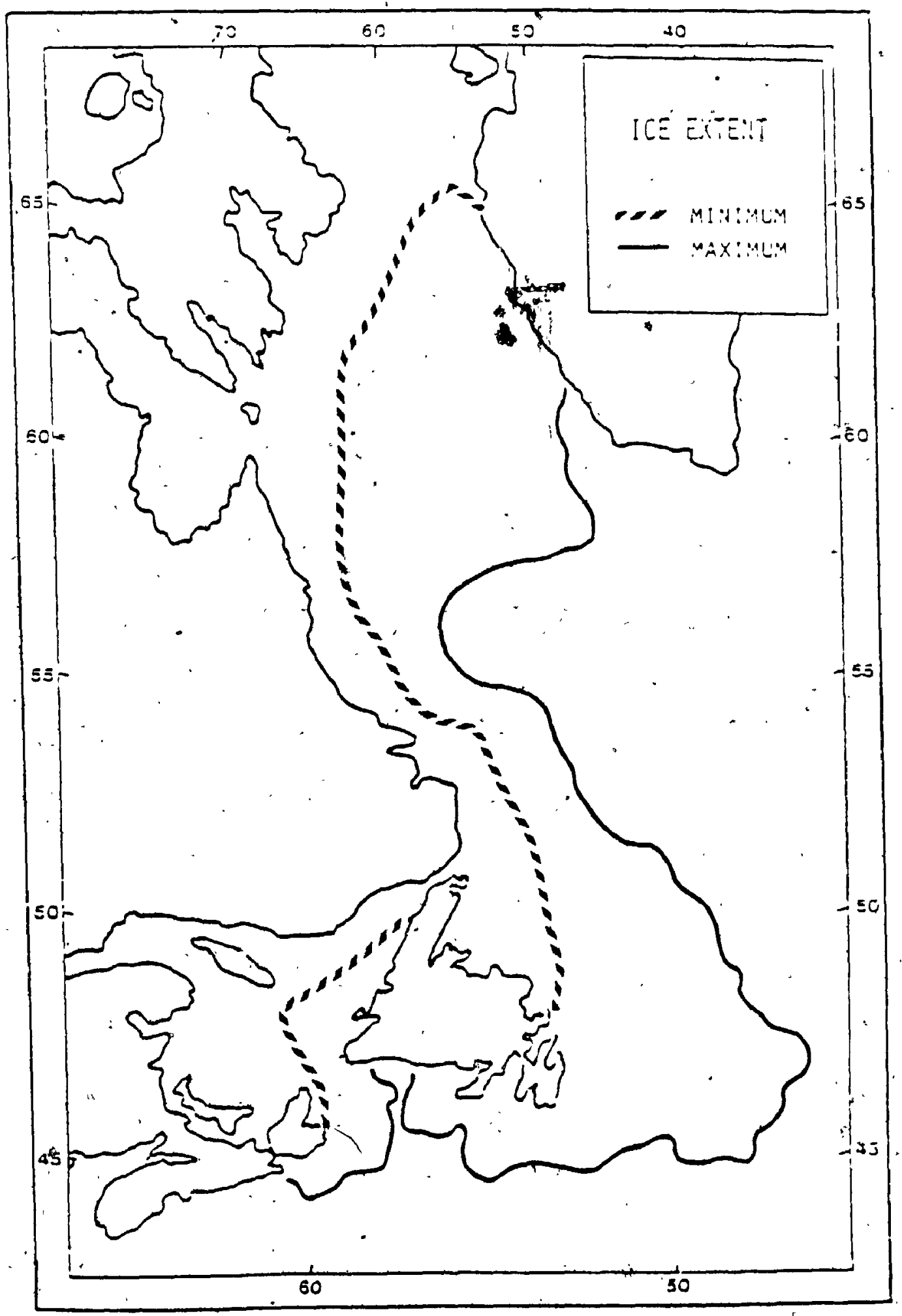


$\cdot 9$

minimum extreme position follows closely to the 1978 and 1981 seasons for the total Eastern Canadian Seaboard. The maximum extreme is a composite of 1975, 1983, and 1985 positions for the Gulf, Davis Strait and East Newfound land Waters respectively.

\subsubsection{Quantitative Analysis}

In order to analyse the maximum ice extent data quantitatively, statistics were generated for two parameters -- ice extent and ice area. Zwally (1984) discusses the importance of these two paraneters in the study of sea ice variability. Sea ice extent refers to the area of ocean covered by ice, i.e., spatial coverage of ice. Sea ice area takes into account the distribution of ice concentration within the pack. Therefore the difference between ice extent and ice area equals the amount of open water within the pack. If ice extent and ice area were equal, then the ice pack would be $100 \%$ compact ice. Therefore the combination of these parameters gives two sources of information -- ice coverage and compactness. The climatic significance of ice area and extent were discussed previously in chapter. 2. The methodology used to derive these parameters is outlined below. - The approach to statistics derivation and display of results follows closely that employed by. Zwally et a l. (1983) in their study of Antarctic ice extents from ESMR data .

\subsubsection{Methodology of Statistics Derivation}

- The 1/10 CMC grid is used as the basis. for deriving the ice area and extent statistics. Each $38.1 \mathrm{~km}$, square grid cell measures 1451.61 
$\mathrm{km}^{2}$ in area. Total ice extent (LE) can be calculated by suming the number of grid squares containing ice (N) and multiplying by 14 bl.6l $\mathrm{km}^{2}$, thus IIE $=N \times 1451.61 \mathrm{~km}^{2}$. Ice area is computed using the ice concentration derived for the grid square. By multiplying the concentration $(C \%)$ by the grid square area $\left(1451.61 . \mathrm{km}^{2}\right)$, a value for the area. $\left(A_{n}\right)$ of that grid square covered by ice is achieved. The total of the ice areas $\left(\Sigma A_{n}\right)$ for all the grid squares containing ice is therefore the total ice area (IA) value for the Eastern Seaboard. Thus $I A=\mathbf{I} \dot{A}_{n}$ where $A_{n}=C \% \times 1451.61 \mathrm{~km}^{2} \quad \therefore \quad \therefore$.

If IE and IA are "calculated for each year in the study period (1973-1985), trends over time for the two parameters are yielded, which can be expressed graphicallica. These trends represent interannual variation in maximum ice conditions for the Eastern Canadian Seaboard, and can be compared to trends in climatic parameters (Chapter 5).

\subsubsection{Computer and Manual Statistics Generation}

"A mainframe computer can facilitate the derivation of the ice area and extent statistics. The SMMR data is suited to this type of manipulation. The ESMK data, on the other hand, is not suited because of the false ice concentrations produced due to rough sea state. The computer cannot distinguish between real and false concentrations; hence errors in the derived ice area and extent values could result with the input of false ice information. A manual method of derivation became the solution to this problem.

An overlay was produced containing the $1 / 10$ CMC grid configuration. 
By overlaying this grid on the maps containing.the ice concentration contours, ice extent and ice area can be derived. The number of squares contained in each contour level were counted and the sum then multiplied. by $1451.61 \mathrm{~km}^{2}$ and the average concentration for the level. For the concentration levels $15-34.9 \%, 35-64.9 \%, 65-84.9 \%, 85-98.9 \%$ and $99-100 \%$, the average concentrations used were $25 \%, 50 \%, 75 \%, 92 \%$ and $100 \%$ respectively. The ice' areas derived for each contour level were then "summed" to yiela a total ice areavalue for the entire study area. The tatal ice extent value is calculated by multiplying the total number of grid squares for a! l concentration levels by $1451.61 \mathrm{~km}^{2}$. This manual method Was used for each year of ESMR data (1973-1978). The list of generated statistics appears in Appendix A.2.

Since average concentrations are used in the manual derivation process, the resulting ice extent and ice area values will deviate slightly from true conditions. The computer-generated statistics will be closer to reality as the ice concentrations from the $38.1 \mathrm{~km}^{2} \mathrm{grid}$ are used in calculations. At each grid cell the derived ice concentration from the SMMR data is stored in a computer file for future'statistical analyses. Computer, generation of statistics involves calculating and summing ice areas from the grid cells, with the final output being values for total ice area and extent for the Eastepn Canadian Seaboard. The computer-generated statistics for the SMMR data (1979-1985) are listed in Appendix A.2.

In order to validate the manual method; it was used for selected 
SMMR dates and compared to the computer-generated results. The manual 1 y-generated ice areas and extent.s averayed $7.2 \%$ and $7.4 \%$ (with all values less than 10\%) lower than the computer-generated values respectively. This difference was deemed acceptable and the manuallygenerated statistics could therefore be used with the computer-generated ones to produce an overall trend (1973-1985).

\subsubsection{Trends in Ice Area and Extent:}

The trends in ice area and ice extent produced from the ESMR and SMMR statistical analyses are graphed in Figure 4.6. Table 4.1 i.ists the corresponding ice area and extent values with maxima and minjina for the perioo highlighted. Interannual variation in Baximum Eastern Canadian Seaboard ice conditions (1973-1985) is evident in the graph. Ice extent and ice area exhibit similar trends with generally decreasing values from 1973 to 1979, followed consistently low values to 1981. After 1981 an increasing trend is noted with a maximum in 1984, fol lowed by a decrease.

The variation in amount of open water within the Eastern seagoard ice pack is also evident in Figure 4.6 as the difference between the "two curves. The variation ranges from $20 \%-30 \%$ of total ice extent over the time period. The year 1978 exhibits the most compact conditions, while 1981 exhibits the least. In terms of actual amount of open water, 1978 exhibits the smallest area.while 1975 exhibits the greatest.

\subsection{Validation of Ice Area änd Extent Trends}

Before proceeding with any climatological analysis of the trends in 


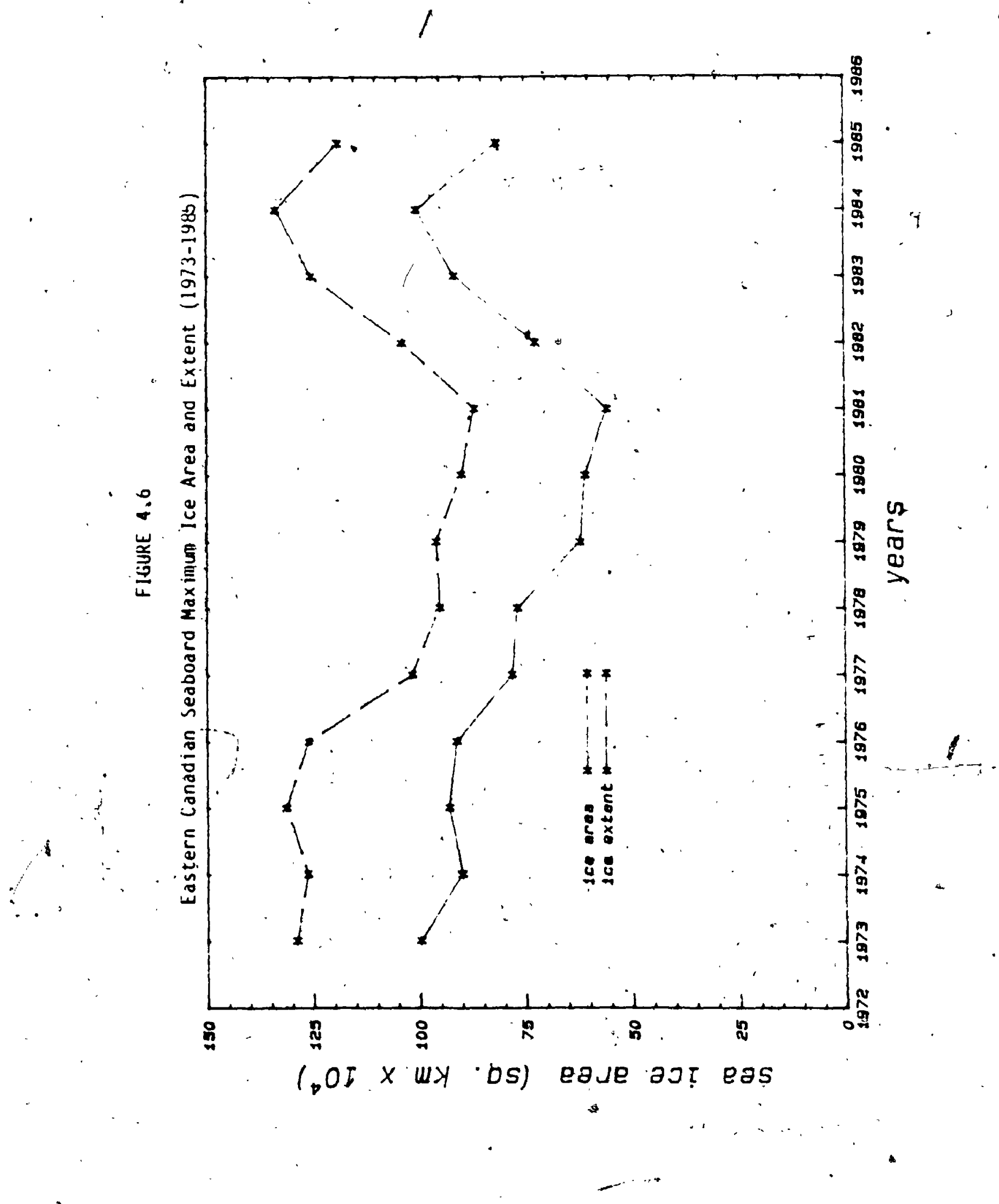


$\therefore \quad$ TABLE $4: 1$

Eastern Canadian. Seadoara Maximum Ice Extent and Area Values ( $\mathrm{km}$ ) $(1973-1985)$

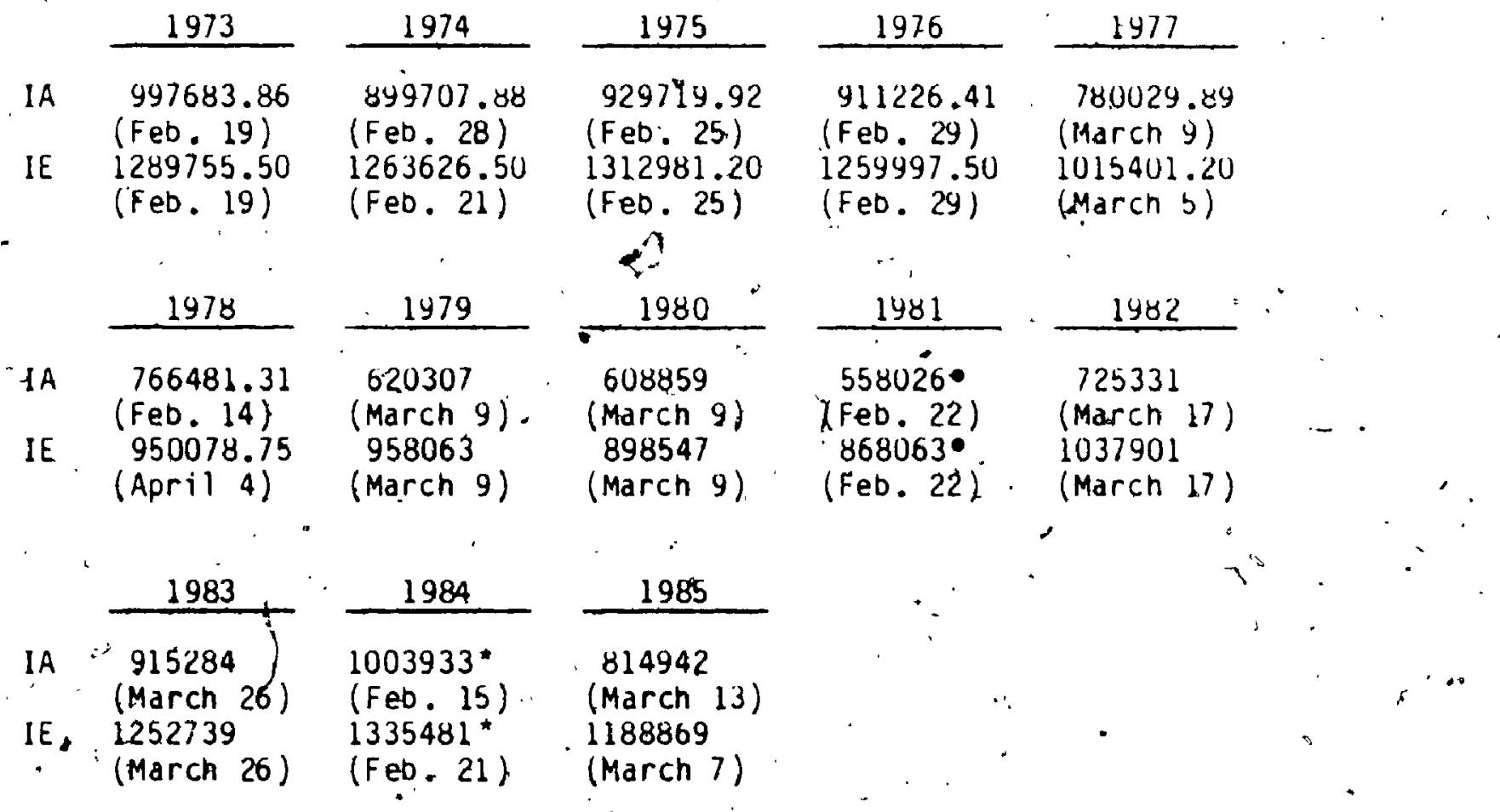

$$
\begin{aligned}
& \begin{array}{r}
\text { Mean Ice Area }(1973-1985)=\$ 10117.79 \mathrm{~km}^{2} \\
\text { Standard Error }=\$ 41329.20 \mathrm{~km}^{2}
\end{array} \\
& \text { mean Ice Extent }(1973 \rightarrow 1985)=1125500.28 \mathrm{~km}^{2} \\
& \text { Standard Error, }= \pm 48032.08 \mathrm{~km}^{2}
\end{aligned}
$$

* -1973-1985 Maximum

- 1973-1985 Minimum

IE = Total spatial extent of icè

$I A=$ Total area of ice (IE minus amount of open water) 
ice area and extent, the values had to be validated through comparison to a conventional sea ice data source. British Meteorological Uffice ice charts were used for this purpose since they provide ice information (position, state and concentration) about-the entire Eastern Canadian Seaboard. These charts, at a scale of $1: 21,597,000$, are produced at the end of each month based on information from a variety of sources including Atmospheric Environment Service composite ice charts, and they cover the northern hemisphere polar region. Figure 4.7 shows a reduced portion of of these charts illustrating Easfern Canadian Seaboard ice conditions for the end of-February 1984.

Using the manual method described in Section 4.4 .3 .2 and an overlay of, $68.6 \mathrm{~km}$ grig squares, valüe for ice extent and area were derived from the closest corresponding British charts to the ESMR and SMMR dates. Figure 4.8 illustrates graphically these trends and provides a comparison to the ESMR and SMMR trends. Correlation coefficients, for a sample size of $n=11$, were generated in order to compare these trends statistiodly. The trends in ice extent exhibit the best correlation: with an $r$-value of 0.91 , white the ice area trends have an $r$-value of 0.77. These values were tested and found to be statisticaliy significant. From this comparison, it was concluded that the passive microwave ice area and extent trends (1973 to 1985) are reasunably valid estimations of actual ice-conditions.

Saulesleja and Phillips (1982) examine maximum ice extent along the Canadian East coast and reporty that the early 1/70's were above nomal 
Example of Eastern Canadian Seaboara Portion of a. uritish Meteorulogical office ice Chart (February 1984)

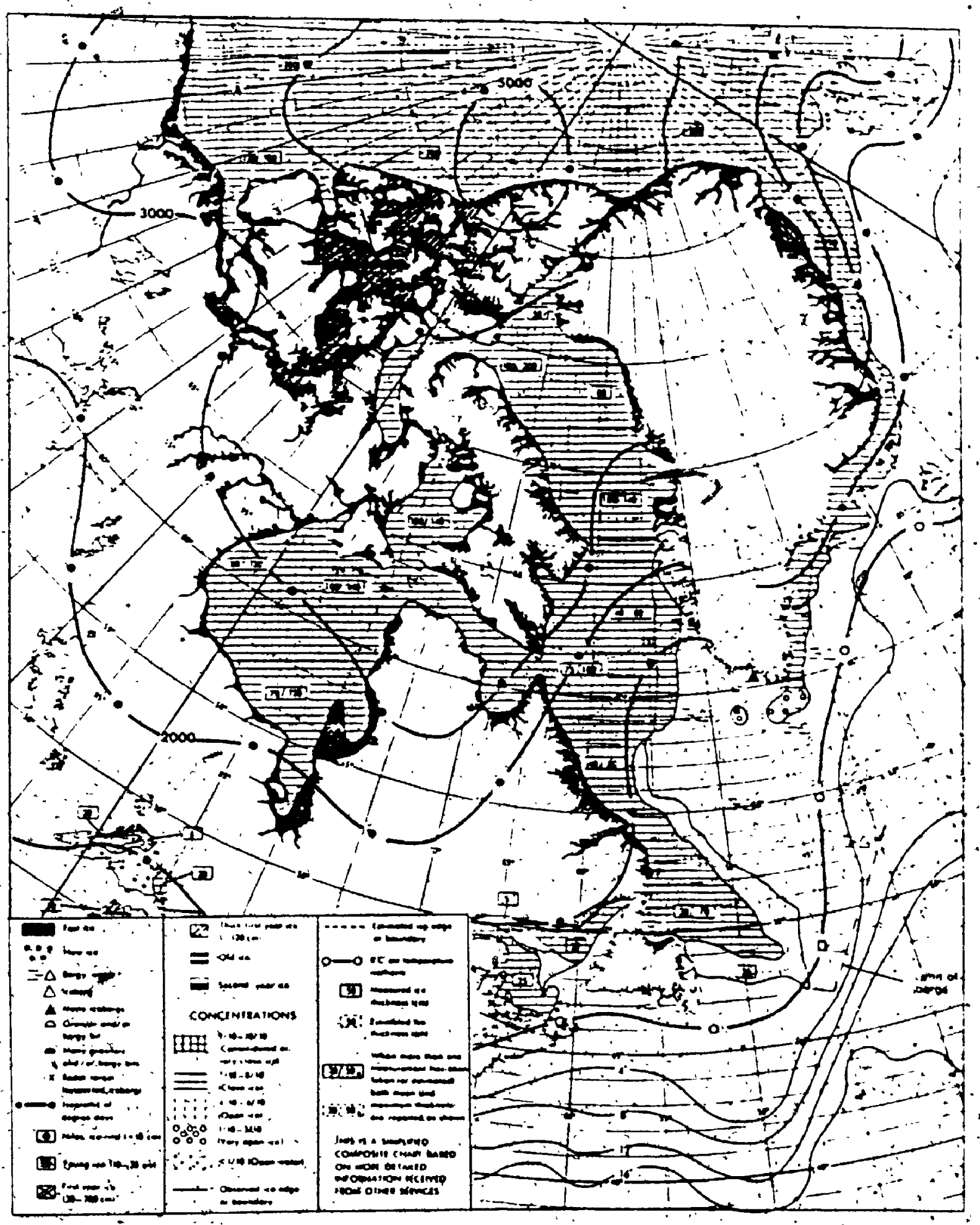




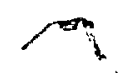

1
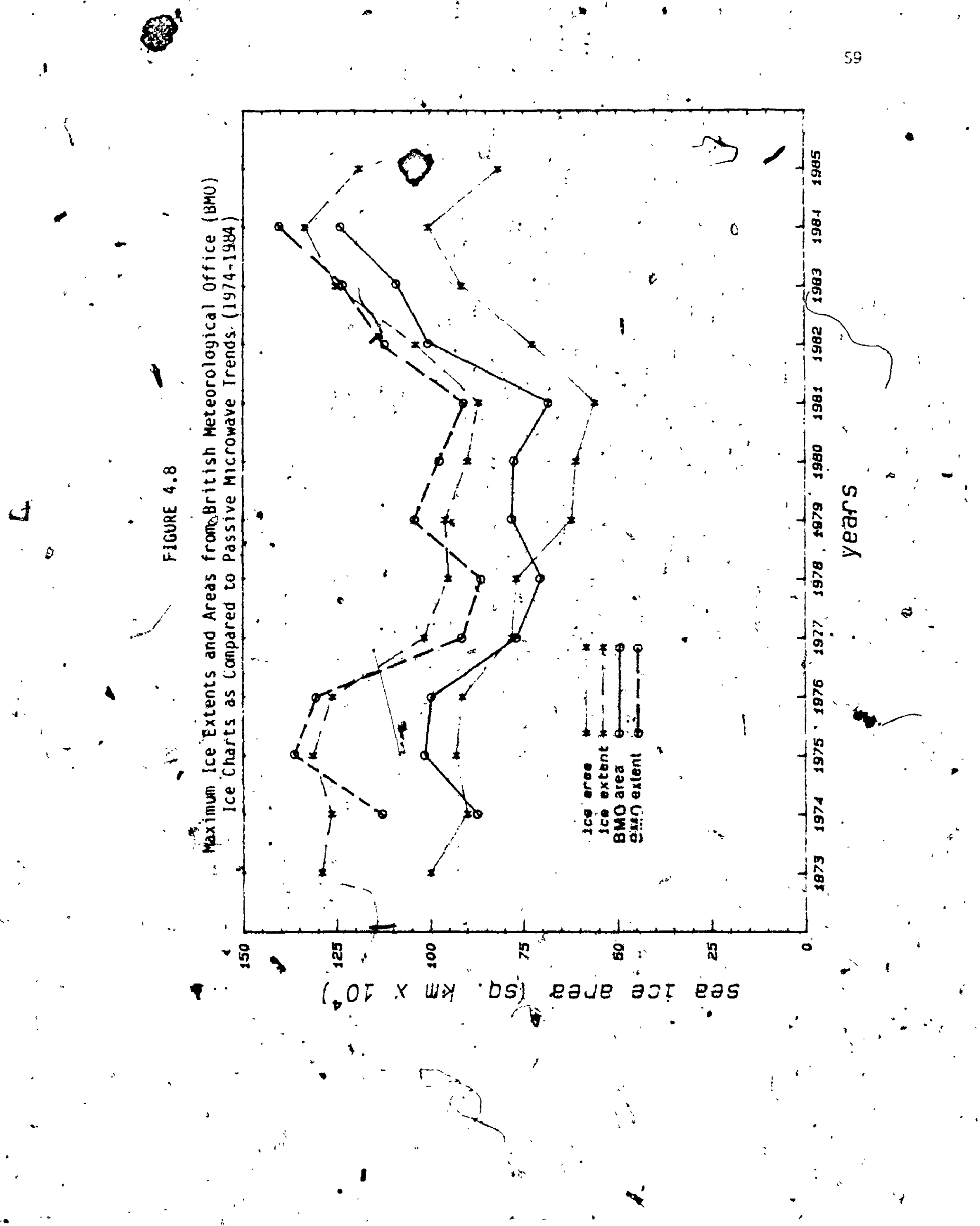
ice years. The values indicated in figure 4.6 reflect this tact. They al so illustrate a decrease in re e extent after 1976, which corresponds to the trend derived foin the passive microwave data. Thus it can be. concluded that the trend in: maximum ice extent for 1973 to 1985 expressed in Figure 4.6 is a reasonably valid one.

o)

j 


\section{CHAPTER 5 \\ EXPLANATION OF SEA ICE INTERANNUAL VARIATION}

\subsection{Introduction}

In order to account for the interannual variation of maximuin ice extent and areadong the Eastern Seaboard, one must look into the climatological and oceanographic state of the area over the time period of intẹrest (ie., 1973-1985). This chapter will investigate the significance of the ice area and extent trends derived from the passive microwave data through comparisens to several climatological and oceangmgraphic parameters. The ci imatological parameters investigated are air temperature, freezing degree day accumulations, winds and the position of the Icelandic Low. The main oceanographic parameter is sea surface temperature. Ocean currents are not examined due to the lack of. available data on interannual variability of current characteriṣtics. The aim of this effort is to explain why this variation is observed; and, if possible, isolate any controlling mecharisms.

The comparisons will mainly be quantitative, but in some cases qualitative analyses can only be used. The quartitative comparisons consist of calculating correlation coefficients (r-values) for each sample (size $=n$ ) and then testing them for significance, according to. the procedures. out ? ined by. Hammond and McCullagh (1978). "The correla-" tion coefficient indicates the degree of. association between two, 61 . 
variables, and the testing procedure determines whether or not any ooserved association could be due to random variations.

\subsection{Climatological parameters}

\subsubsection{Air Temperature}

As discussed in Chapter 3, Section 3.4.2, Alr temperature plays a role, in the production and growth of sea ice along, the Eastern Seabodra. Generally, below-freezing alr temperatures promote ice yrowth. The length of time temperatures remain below $U^{\circ} \mathrm{C}$, and the r severity, will. contribute to the amount of ice produced and the spatial extent to which the cover yrows. Air temperature can vary from year to year; thus the effect on ice seasons can vary from year to year. (In order to investigate the relationship between air temperature and the trend. in ice area - ana extent observed from 1973 to 1985, air temperatures froil coastal. theteorological stations along the Eastern Seaboard were analysed for this time period.

February and March monthly mean air temperatures were first investigated since these months represent the time at which.maximuq ice extent occurs. The air teheratyre means for the study area are listed in Table 5.1, while the individual station temperatures can be founa in AppendiK A.3. Figure 5.1 graphically compares ice extent and area to the February and March monthly means. The air temperature means can be described genera!ly as being erratic. and they do not follow as clear a pattern as the sea ice trends. Correlation coefficients were calculated in order to determine the degree of association between the monthly air $\therefore$ 
TABLE 5.1

Eaštern Canadian Seaboara February and March Mean Alr Temperatures $\left({ }^{\circ} \mathrm{C}\right)$ $(1973-1985)$

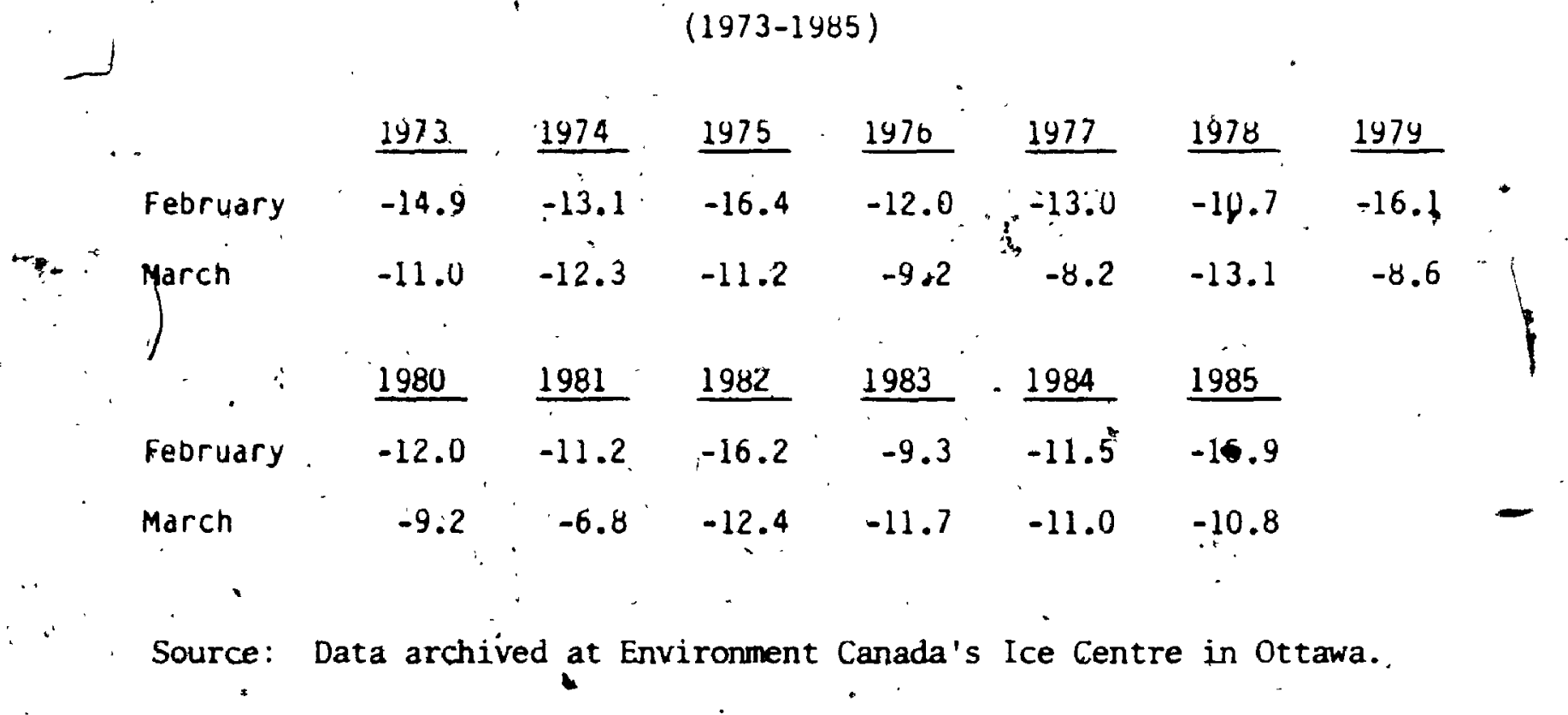


$Y$

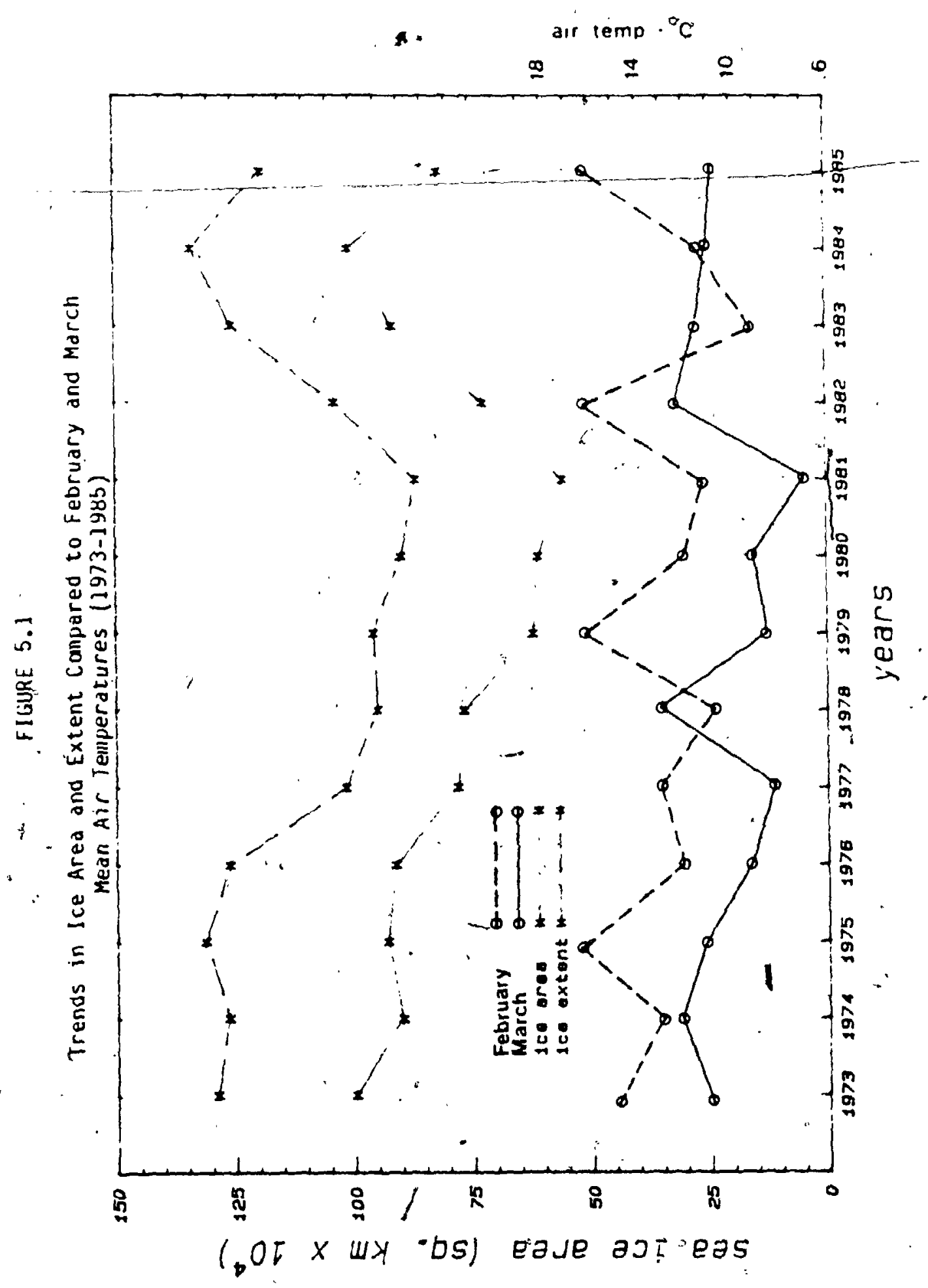


temperature means and the ice values. These are listed below:

February Temp. Mean vs. Ice Area $=0.0236 \quad(n=13)$
February Temp. Mean vs. Ice Extent $=-0.1045 \quad(n=13)$
March Temp. Mean vs. Ice Area $=2-0.5324 \quad(n=13)$
March Temp. Mean vs. Ice Extent $=-0.4526 \quad(n=13)$

The testing of these values indicates that there is little association between the february monthly mean temperatures and ice area and extent, and al so between March temperature and ice extent. Their r-values were not significant at the lowest acceptable confidence level (95\%). The correlation with ice area shows a slightly higher negative $r$-value which when tested is significant at the lowest acceptable confidence level (95\%). The March mean temperature pattern therefore shows a weak association with the trend in ice area. "The negative value indicates that" an increase in ice area corresponds to a decrease in air temperature.

The same approach was applied using a 'seasonal' mean instead of a monthly mean. A seasonal mean takes into account air temperature characteristics during the period of ice growth up until the time of maximum (extent. Jacobs and Newell (1979) use this approach for Davis Strait and Baffin Bay ice conditions. The December to February time period was chosen as representing the 'wintér season' since, "on average, maximum ice extent is attained at the end of February. This time period is also consistent with that used by Jacobs and Newell (1979). December, January and February monthly air temperature means for coastal meteorological stations were averaged, the result being a representative seasonal mean. Table 5.2 lists the average seasonal means for the study. area for 1973 to 1985. The individual seasonal means for the meteorolo- 


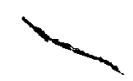

1

TABLE 5.2

Eastern Canadian Seaboard Seasonal Air Temperature Means $\left({ }^{\circ} \mathrm{C}\right.$ ? (December-February, 1973-1985)

$\begin{array}{llllllll}\frac{1973}{-14.3} & \frac{1974}{\vdots} & \frac{1975}{-12.4} & -14.1 & \frac{1976}{-12.6} & \frac{1977}{-10.9} & \frac{1978}{-11.0} \cdot-10.8 \\ \frac{1980}{-10.5} & \frac{1981}{-10.9} & \frac{1982}{-11.6} \cdot \frac{-1983}{-13.5} & \frac{1984}{-13.0} & \frac{1985}{-10.4} & \end{array}$

Source: Data archived at Environment Canada's Ice Centre in ottawa.

a) 


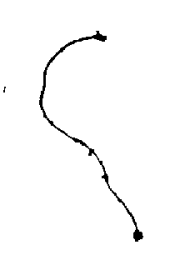

gical stations used are tatied in. Appendix A.3. Figure 5.2 exhibits the trend in the seasonal air temperature mean...as.compared to the trends in ice area and extent. The seasonal air temperature, curve follows a similar pattern. as the ice curves, with the coldest temperatures corresponding to periods of high maximum ice extent. Correlation coefficients (r-values) calculated for these curves are listed below:

Seasonal Temp. Mean vs.' Ice Area $=-0.8189\left(n=\frac{1}{1} \frac{1}{3}\right)$

Seasonal Temip. Mean vs. Ice Extent $=-0.8159, \quad(n=13$.

These values were tested using the correlation test formula "foom Hammond and McCumagh (1978) and found to be significant at the highest (99.9\%) confidence level. Thus, it can be concluded that there is a significant (correlation) association between the December to February seasonal air temperature mean and maximum ice area and extent during the 1973 to 1985 time period. The negative correlation indicates that decreasing seasonal air temperature corresponds to increasing ice area, and vice versa:

\subsubsection{Accumulated Freezing Degree Days}

Accumulated freezing degree days (FDD's) are related to air temperature as out lined in Chapter 3, section 3.2.1. The FDD accumulations are representative of the amount, of freezing which has taken place throughout the season. The relationship between FDO's and ice conditions has beentionvestiyated andureported in the literature beginning with Zubor (1945). More recentiy, Btielilo (1961) has derived equations relating fuo's to growth and decay of ice thickness in the Canadian. 


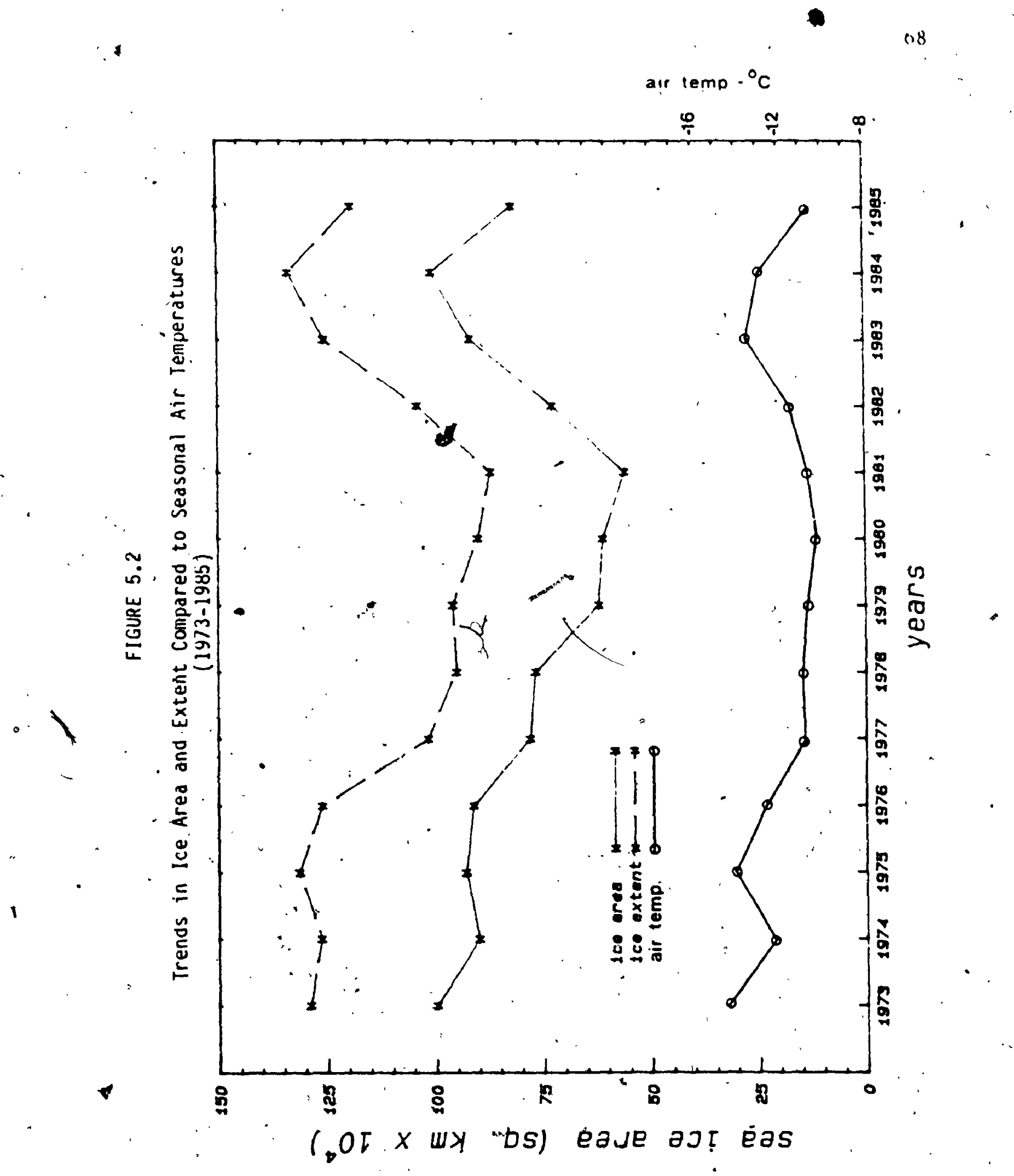


$B$

Arctic Archipelago. Thy significance of FOO's to ice growth indicates that there may be a relationship with spatial extent of ige as well. Therefore it was decided that FDO's should be exanined for the Eastern Seaboard as part of accounting for sea ice maximum extent interannual variability.

- FU0' accumulations to the end of February (average time of maximum ice extent) for coastal meteorological stations were averaged to produce *

a mean value for the Eastern Canadian Seaboakd. Table 5.3 Jists these values for each year from 1973 to 1985. Indivroual station accumulations are tabled in Appendix A.3. Figure 5.3 expresses graphically the trend in mean FDD accumulations as compared to the variation in ice area and extenty The pattern in the FOD curve is similar to the ice curves, with highest FOD accumulafions corresponding to maxima in ice area and extent. Correlation toefficients for the curves are listed below:

FDD Accumulation vs. Ice Area $=0.7853 \quad(n=13)$

FUD Accumulation vs. Ice Extent $=0.7823 \quad(n=13)$

These $r$-values were tested and found to be statistically significant at the $99.5 \%$ confidance level. Thus, Eastern Canadian Seaboara Fod accumulations (to the end of February) are significantly associated with ice area and extent along the Eastern Canadian Seaboard for the period 1973 to 1985. The positive correlation indicates increases in FDD's correspond to increases in ice area and extent valuès, and vice versa.

\subsubsection{Position of the Icelandic Low}

The relationship between the interannual variation in the position of the Icelaridic Low and variations in ice extent has been investigated 
TABLE 5.3

FOD Accumulations for the Eastern Canadian Seaboard to the End of. February (1973-1985).

$\frac{1973}{1642.7} \frac{1974}{1258.4} \frac{1975}{1525.9} \quad \frac{1976}{1418.0} \frac{1977}{1255.6} \frac{1978}{1259.6} \frac{1979}{1324.7} \cdot$

I

$\frac{1980}{1203.3} \cdot \frac{1981}{1257.7} \frac{1982}{1207.4} \frac{1983}{1543.6} \frac{1984}{1566.1} \frac{1985}{1340.1}$

Source: Data archived at Environment Canada's. Ice Centre in Ottawa. 
FDD Accumulation.

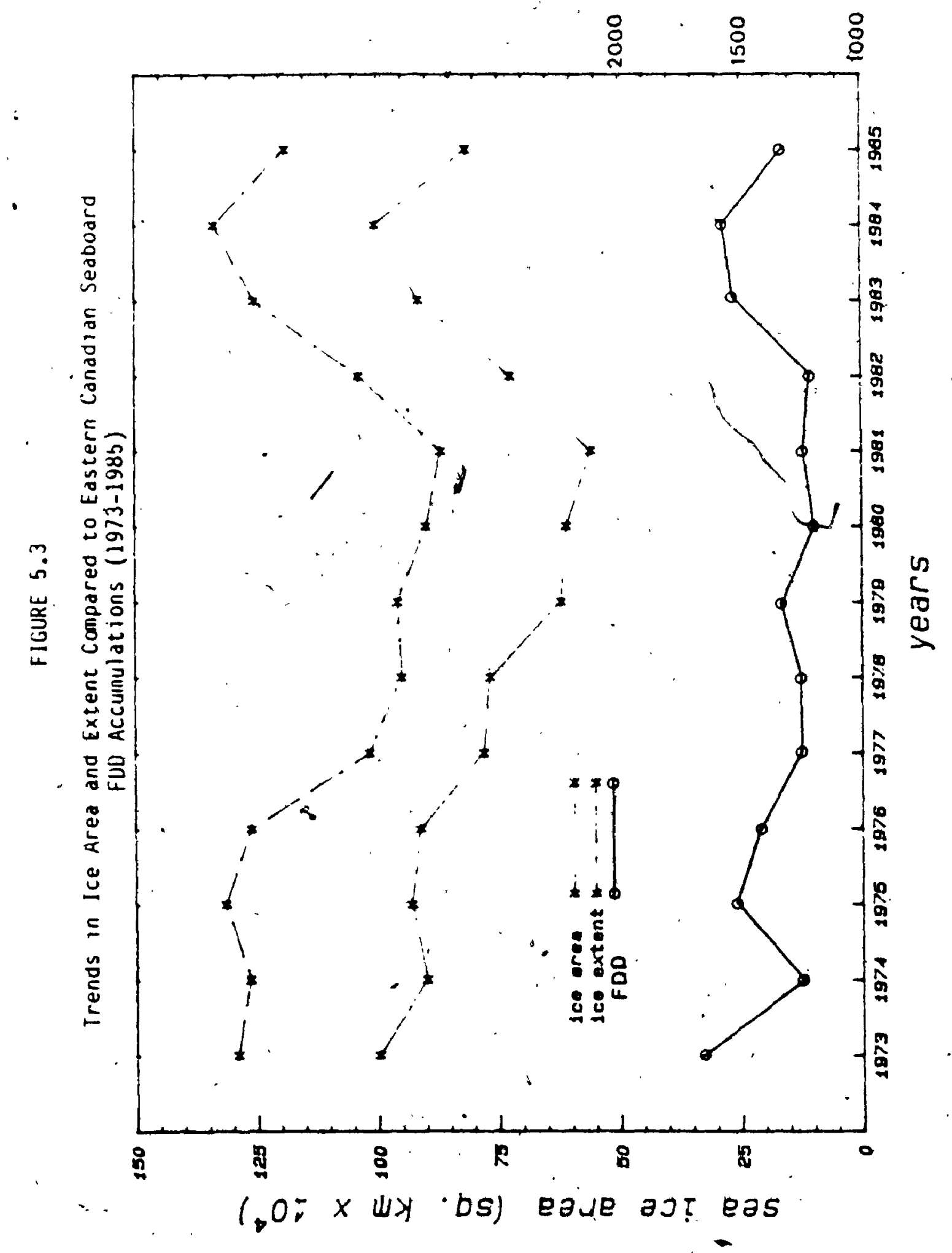


and documented: As discussed in chapter 3 (Section 3.4.2) the arection of displacement of the Icelanaic low exerts an influence on ife extent. In.the Eastern Arctic. Johnson (1980) indicates that Arctic sea ice is of greater \&xtent than normal when the Icelandic Low is stronger drio displaced to the northeast. As reported by Van Loon and Madoen (1y83), the Low tends to move east as it moves north, and as it moves south it also moves west. The movement of the fcelaric Low tolthe suuthuest results in mild wrnters for the Eastern Arctic due to warm air dovection over Greenland (Royers, 1985). Based on the results of these investiyations; the gxamination of Icelandic Low interannual varlability over the 1973. to $1985^{\circ}$ time perfod is a necessary component in accounting for ine interannual vafiability sèen in ice extent and area. .

- Figure 5.4 exhibits the mean January-Februaty"position of the Icelandic Low as derived from monthly mean lơv m11 libar pressure charts (archived at Environment Canada's Ice Centre). The iverage pastfrón ot the Icelandic Low during the winter is soothicest of lceland in the vicinity of $60^{\circ} \mathrm{N}, 30-40^{\circ} \mathrm{H}$. The positions exhibited in figure 5.4 may be classffied as being north or south of the usual location of the Low. Table 5.4 lists the classifications of these positions by year.

The values for ice area and extent from Table 4.1 can, be classified - in a similar manner, according to above mean conditions, belaw mean conditions and approximating mean conditions. Mean conditions are defined as ice extent and area values occurring within one standara error (SE) of the 1973-1985 mean. The classifications by year are 

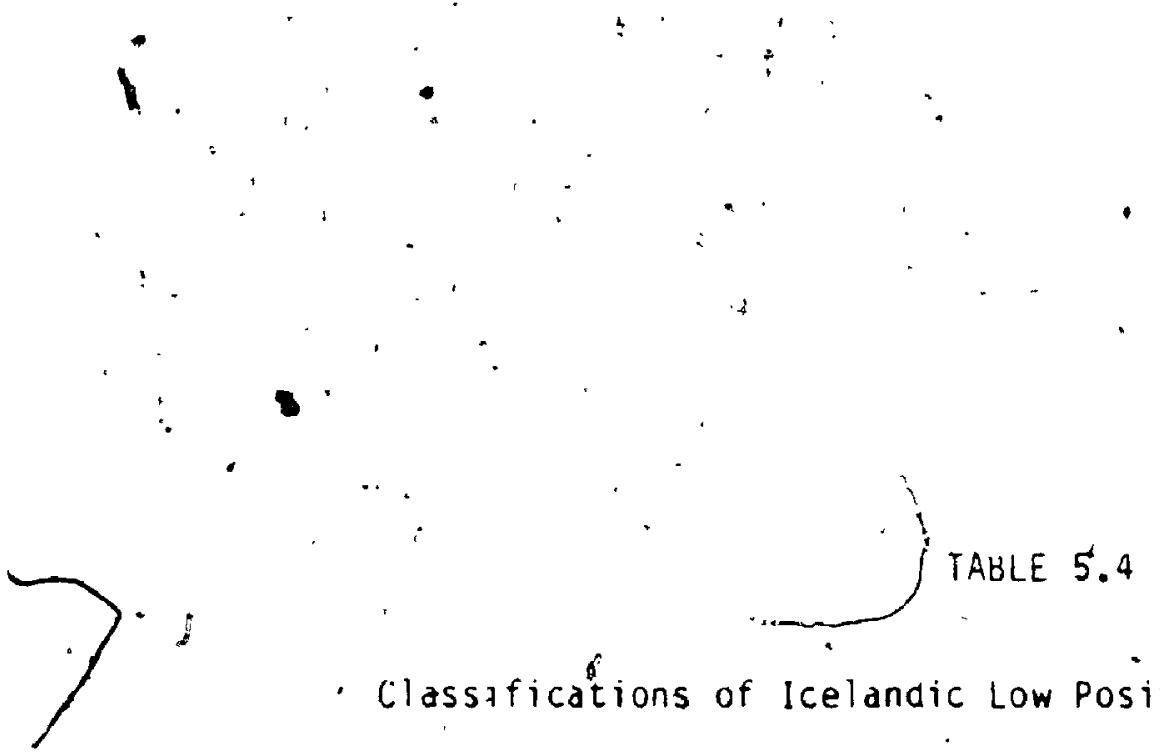

$-4$

- Classifications of Icelandic Low Positions and Eastern canadian Seaboard Maximum Ice Extents (1973-1985)

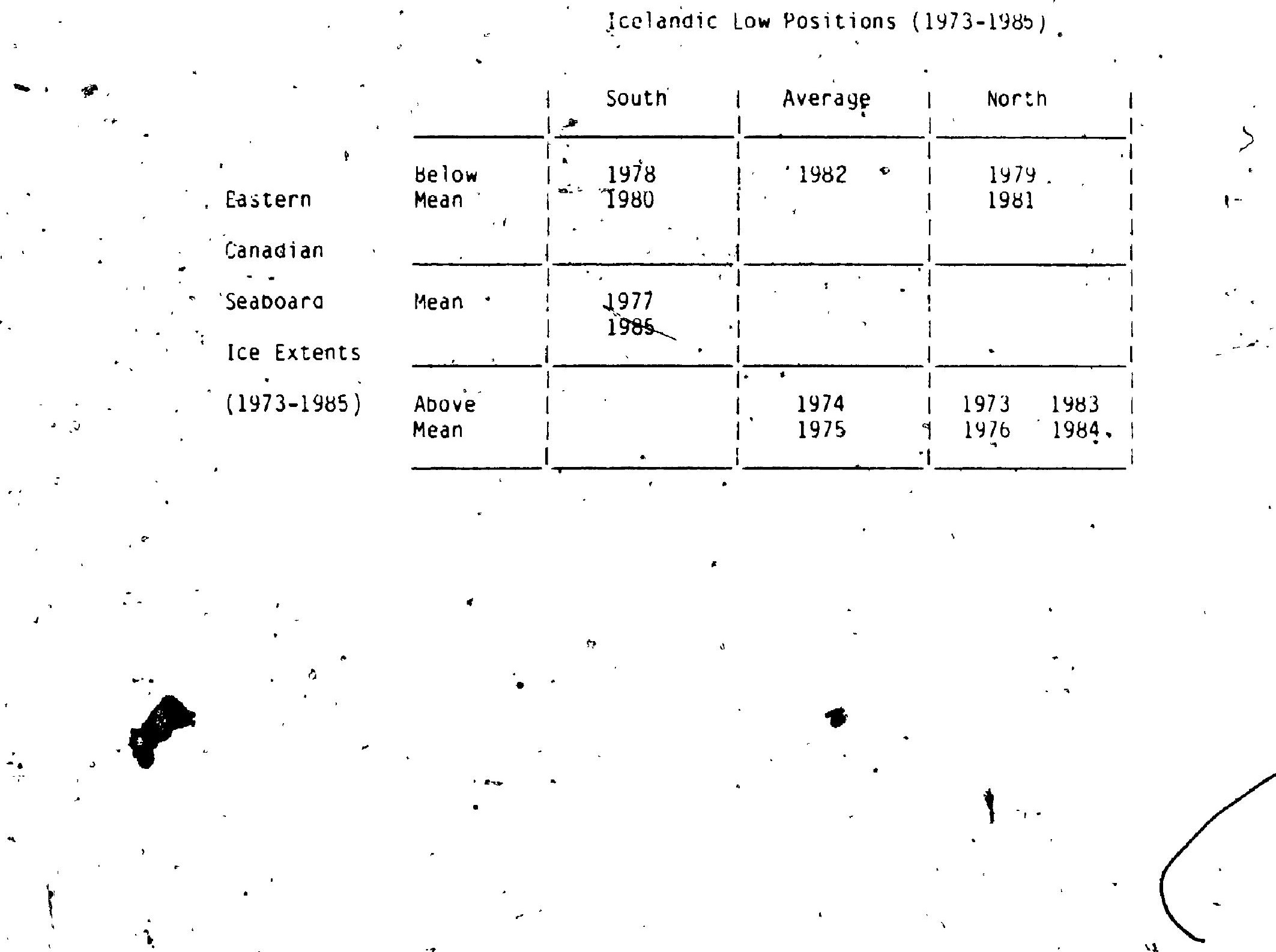


listed in Table 5.4.,

The cross-classification format of Table 5.4 facilitates the comparison of the Icelandic Low pasitions and the ice areas and extents. The years 1978 and 1980 , with below mean ice extent, correspond to southern positions of the Icelandic. Low. The years 1973, 1976, 1983 and 1984, with above normal ice conditions torrespond to northern pasitions of the Icelandic Low. These years therefore are consistent with the findings of Johnson (1980) and Rogers (1985). The years 1974 and 1975 , which are classified as having above mean ice exterfis, correspond to normal positjons of the Icelandic Low. The Low is also in a norma'l position during"1982, which is classified as having a below meanice. extent. Since these years do not follow the expected results, some other factor must have affected the ice growth to produce anomalies in extent. The years 1985 and 1977 had ice extents clase to the mean of the 13-year period, but the positions of the Low were south of the narmal position. In fact, "these two years had the most southerly positions of all the years. Therefore, the extreme southerly positions had litile influence on jce extents along the Eastern Canadian Seaboard. The years 1979 and 1981 have ice extents and Low positions opposite to what is expected. Both years have below mean ice extents corresponding with northerly positions of the yelandic Low.

To sumarize, 6 years out of the 13 -year study period had ice extents and lcelandic Low positions that are consistent with" the findings of Johnson (1980) and Rogers (1985). This represents on ly half of the time period. Therefore the relationship between ice extent and 
the winter Icelandic Low position is not consistent for the Eastern Canadian Seaboara.

\section{2 .4 Winds}

Uuring the winter months, wath the influence of a normal position of the Icelandic Low, the -provailing wind direction along the Eastern Canadian Seaboard is from the west to northwest direction. A westerly wina brings coloair from the canadian interior atowill luove the ice offshore, thus increasing. ice extent. It follows therefore that above normal wind speeds would result in above normal ice extent. Symonds (1984) indicates that increased wind speed results in conditions more conducive to ice formation by increasing the aur-sea heat flux. For these reasons, prevailing wind direction and speed data for the 1473 to 1985 time period were conpared to the ice-area and extent trends.

Table 5.5 lists the February (1973-1985) prevalling winds for a selection of meteorological stations along the Eastern Canadian. Seaboard. The data were extracted from Environment Canada Monthly Record publications archived at the Ice Centre in uttawa. Except for d. few cases, the westerly wind is listed as the prevailing wind. for all stations. In 1981, which experienced the smallest maximum ice extent, Grindstone Island and Battle Harbour reported a prevailing south wind. which is generally known to be warm. The remainder of the stations, though, reported the usual westerly direction. Examination of the wind speeds does not yield any specific pattern. Maximum and minimum speeds occur in different years for all the stations. The year 1982 has three 


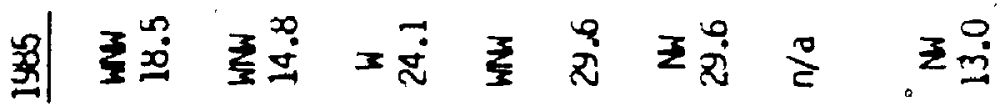

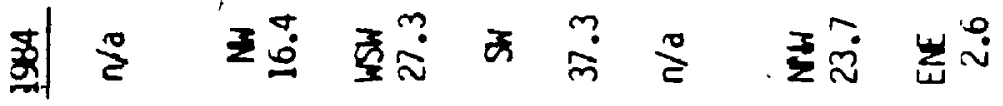

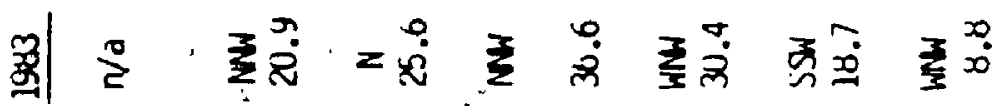

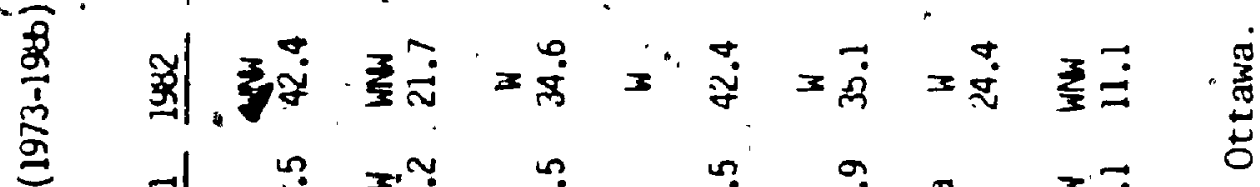

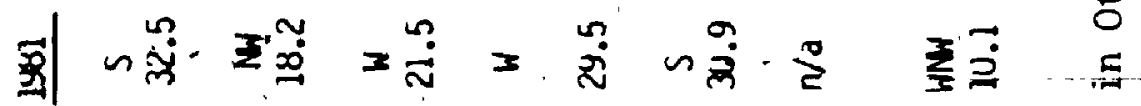

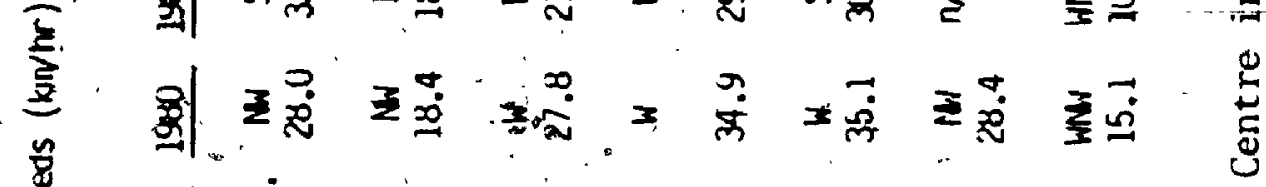

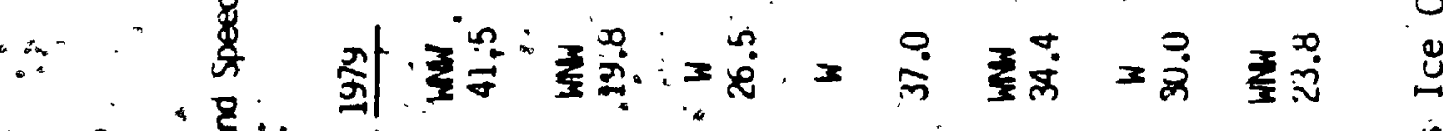

范

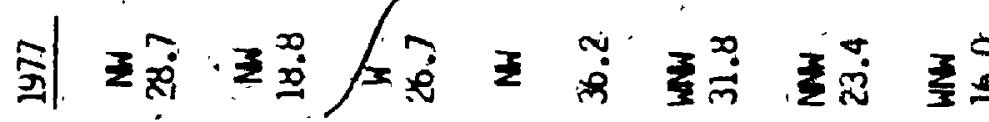

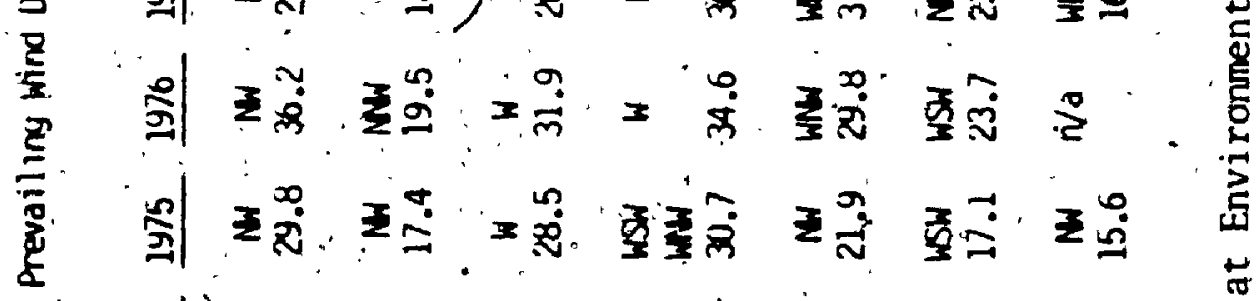

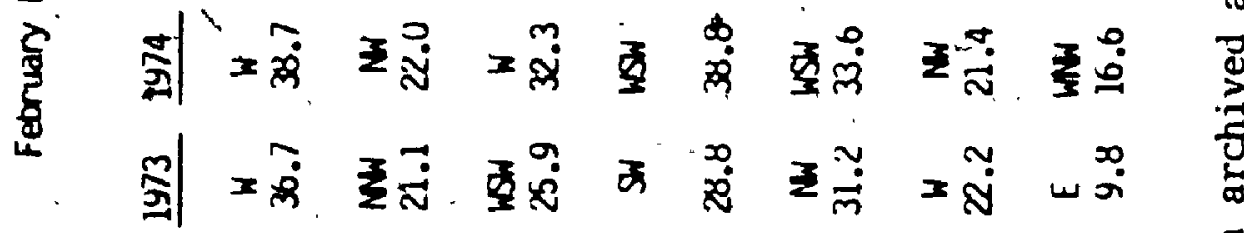

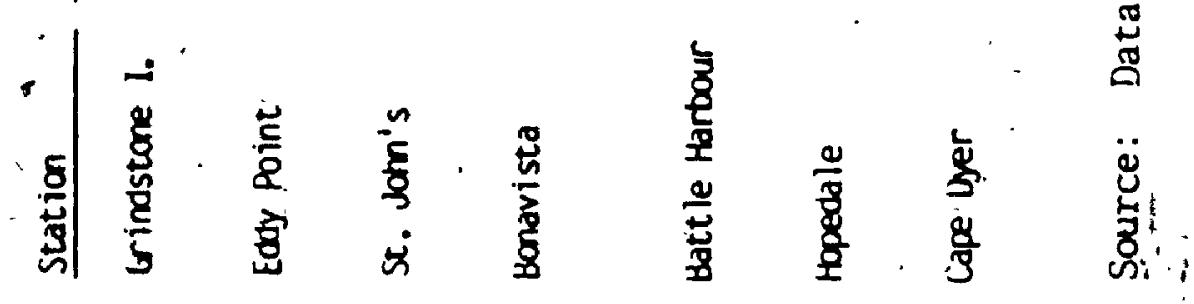


stations reporting high winds, but this does not correspond to above average maximum ice conditions.

The prevailing wind data collected therefore does not, on its own, explain the interannual variability in ice extent. Saulesleja and. Phillips (1982) examined monthly geostroghic wind speeds for a station in the Labrador Sea and concluded that winds in the 1970's were stronger than in the 1960's. These higher than usudl winas speeds agree with the higher than normal ice extent observed in the early 1970's.

\subsection{Uceanographic Parameters}

\subsubsection{Sea Surface Temperature}

Sea surface temperąture exerts a contról over maximum ice extent in that colder water temperatures are more conducive to ice growth. Thus it follows that above normal water temperatures would correspond to below normal ice extent and vice versa (Symonds, 1984). In accounting - for the ice extent.variation seen in the passive microwave data; it is therefore necessary to examine sea surface temperature trends for 1973 to 1985:

Oceanoyraphic conditions for the Northwest Atlantic covering the 1970-1979 decade have been exanined by. Stein (1.982) and Trites (1.982). Tritfs. (1983) and Trites (1984) extend the ahalys is to include the years 1980 to 1983. These investigations therefore cover almost completely the time period of interest.

Trites (1982) presents a review of interannual variability in sed surface temperature for severa'l regions along the Eastern Canadian 
Seaboard, including the Labrador Shelf and Sea, the Grand Banks and the

- Gulf of St. Lawrence. These regions lie within the Northwest Atlantic Fisheries Organization (NAFO) convention area, as does the entire Eastern Canadian Seaboard as il lustratéd in Figure 5.5. Sea surface temperature anomalies are al so analysed for $1^{\circ} \times 1^{\circ}$ gria squarè for geographic areas within NAFO subareas 2,3 and 4. For the 1970-79 decade, Trites reports a coaling trend occurring from 1970 to 1975, with surface temperatures returning to normạl by 1978.

Stein (1982) examines autumn sea surface temperature anomalies for the Labrador Current, covering the years 1969. to 1980. For his analysis the Labrador current is divided into two components - the polar component along the continental shelf, and the Iminger current (warm component) which is seaward of the shelf. Steifi concludes that during the early 1970's negative temperature anomalies were évident, mainly in the" Irminger part of the Labrador Current. From 1974 to 1978 a general increasej in temperature is evident; corresponding with warming of the polar component of the current. A declining trend is reported in 1979 and 1980 for the Irminger component, while 1980 saw increasing temperatures for the polar component. Stein therefore agrees with Trites (1982) on the cooling trend in the first half of the decade, fol lowed by the warming trend.

- Trites (1983) presents a table of sea surface temperature anomalies for the 1972 to 1982 time period for East Coast water masses. Regions corresponding to the Eastern Canadian Seaboard study area are extracted 
F IGURE 5.5

The NAFO Convention Ared

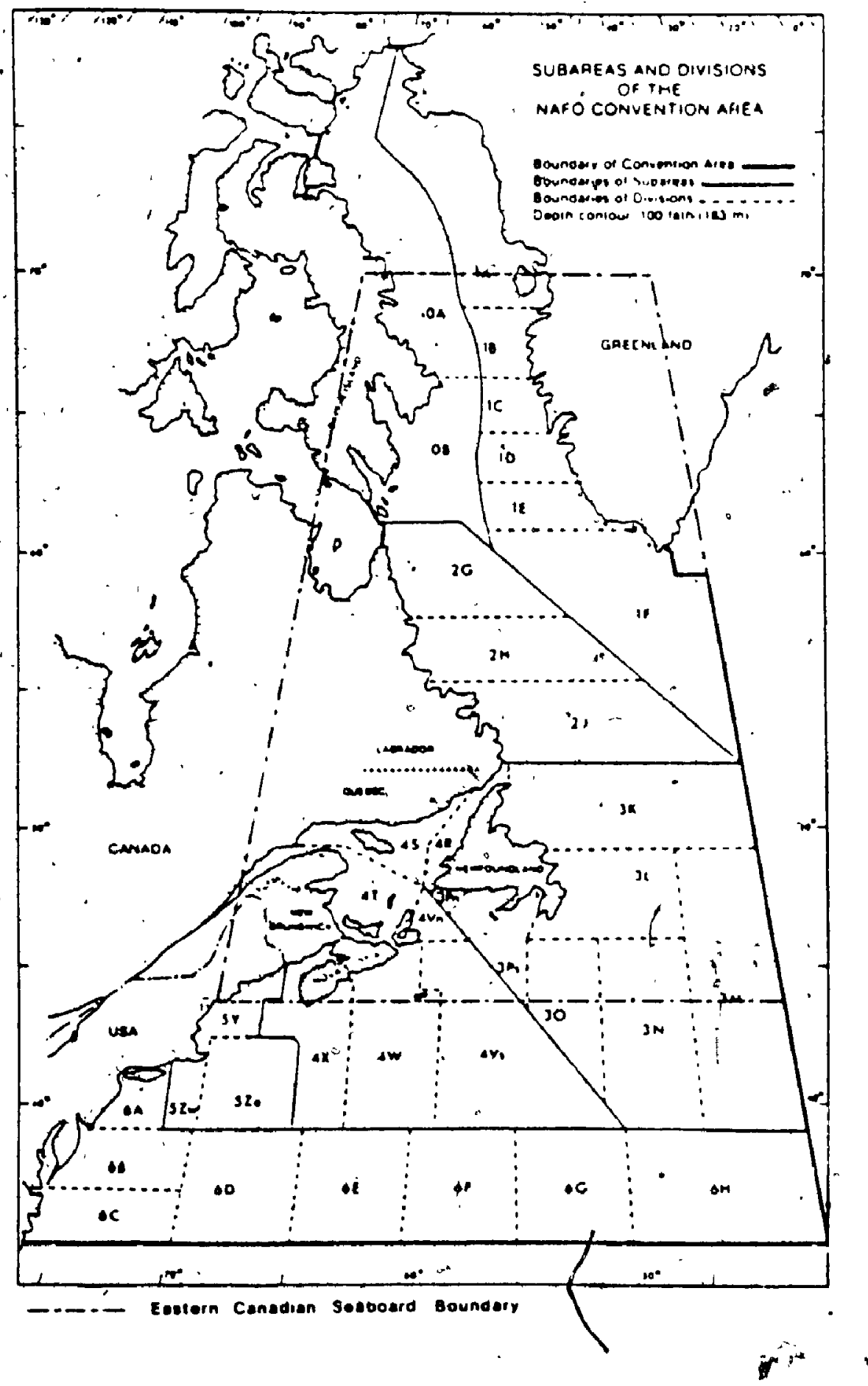

Adapted from: Ounbar (1982) 
and isted in rable 5.6. A mean anomaly value is calculated for all the regions for each year, and the resulting trend is presented graphically in Figure 5.6. Since the SST anomalies correspond to regions south of $50^{\circ} \mathrm{N}$, there may be I imited correlation with ice extent over the Eastern Seaboard as a whole. Data from the regions north of $50^{\circ} \mathrm{N}$ would be necessary. By comparing visually the curyes in Figure 5.6 some (qualitative) observations can be made. The year 1981, which exhibits the lowest ice, area and extent values, also shows the largest positive SST anomaly. The SST curvé does portray a negative to positive SST anomaly trend from 1973 to 1979, which matches the decreasing trends exhibited in. ice extent and area over the same time period. Correlation coefficients were calculated for the curves and are listed below:

SST Anomalies vs. Ice Area $=-0.7917 \quad(n=10)$

. SST Anomalies vs. Ice Extent $=-0.7813(n=10)$.

Both $r$-values were tested and found to be statistically significant at the $99.5 \%$ confidence level. The SST anomalies are negatively, associated with the ice area and extent values, as expected. Negative SST anomalies correspond to increases in ice area and extent, while positive, Ssit anomalies correspond to decreases.

Trites (1984) presents sed surface temperature anomalies from 1972 to 1983 for subareas corresponding to the Labrador Uffshore, the East Newfoundland Waters and the Gulf of St. Lawrence. Foigure 5.7 outlines "his results with these areas highlighted. Observed in this figure is a period of negative SST anomalies from 1972 to 1975 over most of the region. The years “1977 to 1983 are-characterized by above normal SST's. 
$7^{\text {TÁBLF } 5.6}$

Sea Surface Temperature Anomalies $\left({ }^{\circ} \mathrm{C}\right)$ for the Eastern Canadian Seaboard (1973-1482) Region. $\quad \underline{1973} 197419751976197719781979^{\circ} 19001981$

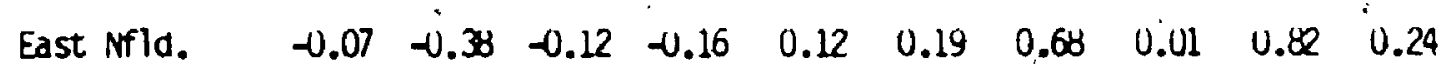
$\begin{array}{llllllllllll}- & -0.25 & -0.57 & -0.30 & 0.22 & -0.11 & 0.27^{*} & .0 .61 & 0.20 & 0.46 & 0.40\end{array}$ $\begin{array}{lllllllllll}\cdots & -0.11 & -0.33 & -0.63 & 0.34 & 0.16 & 0.31 & 0.30 & -0.08 & 1.19 & 0.19\end{array}$

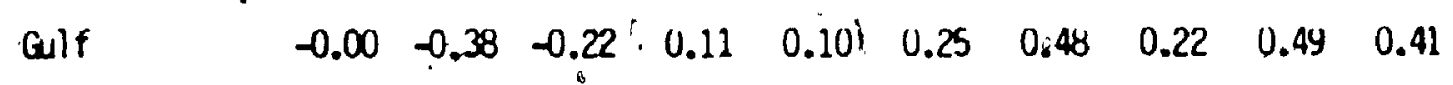
$\begin{array}{llllllllll}-0.28 & -0.39 & -0.43 & 0.07 & 0.03 & 0.35 & 0.49 & 0.03 & 0.66 & 0.20\end{array}$ $\begin{array}{llllllllllll}\text { Mari } & -0.14 & -0.41 & -0.34 & 0.16 & 0.06 & 0.27 & 0.51 & 0.08 & 0.82 & 0.30\end{array}$ - Ox Sour 


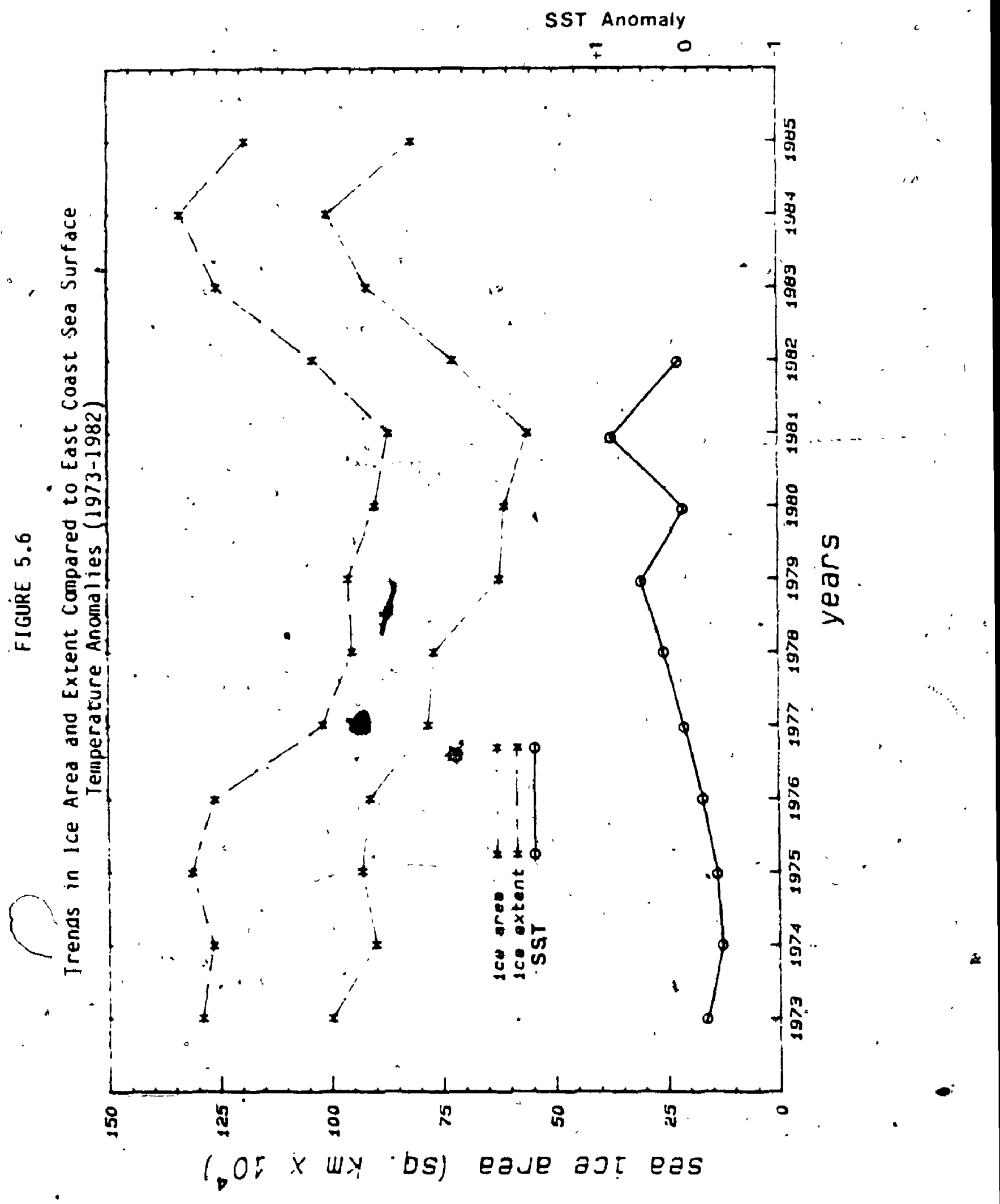



The results of these sea suriace temperature. investigations (Trites, 1982; Stein, 1982; Trites, 1983; Trites, 1984) compdre favourably with the ice extent and area trends for the Eastern Canadian Seaboard. Geherally, years with colder than normal SST's correspond to above normal ice extent, and vice versa, as expected. The largest positive anomaly (Trites, 1983) does in fact correspond to the year of least maxinum ice extent and area for the 1973 to 1985 time period.

\subsection{Significance of the clinatological and Oeeanbgraphic Comparisoms}

The objective of the climatological and oceanographic comparisons has been to account for the interannual variability observed in the ice extent and area values for the Eastern Canadian Seaboard. The seasonal dir temperature and accumulated freezing degree day values showed the highest statistical correlations with the ice extent and area trends. Since the air temperature and freezing degree day parameters are both indications of the severity of a winter, the high correlations are to be expected. Markham (1976) indicates that variation in ice cover can be

$\%$ inferred, from winter air temperature records, since air temperature is closely related to the degree of ice formation. The results of the seasional air temperature and 'FOD comparisons are evidence of this rela-. tionship. The degree of association between the two variables was determined by performing a bivariate correlation. The resulting $r$-value of $-0.8550(n=13)$ was statistically significant at the highest confidence lever of $99.9 \%$. Therefore the sedsonaliair temperature and FFO accumulation variables are reasonably associated. As expected, the rela- 


\section{tionsh!p is such that decreases in temperature correspond to. Increases in FDD aćcumulations.}

The: sea surface temperature comparison al 50 exhibited favourable results in terms, of explaining ice extent variation. The resules support the relationship that abnormally cold. water is assciciated with'

- above nogmal. ice. extent, and above normal temperatures with below norna! -jce: extent (Dunbar, 1982; Symonds, 1984). Trites..(1984) Indicates that sea surface teraperature anomal fere closely. I inked with air timperature patterns. As a result; it is not surprising that the alr temperdture and water. temperature comparisons to'ice extent both yielo positive résults: A.forrelation coefficient of 0.6561 ( $n=10)^{2}$ was calculated for the two variables, and a test of the value indicated statistical significance at the $97.5 \%$ confidence level. This confirms the close. association between a ir temperature fho sea surface temperature.

The results of the position of the Icelandic Low'comparison with ice extent are not straightforward. only 6 out of the 13 years exhidit ice extent and Low positions which"correspond to the results of previous stidies. Thus, it is not possible to concrude that the variation in the lcelandic Low winter position accounts for the interannual variability $\therefore$ in ice extent from 1973 tro 1985. The Icelandic Low controls the winter air circulation along the Eastern Canadian Seaboard, therefore affecting wind and temperature characteristics. It is the dir temperature pattern which shows a more direct pattern correlation witn ice extent. The position of the Icelandic Low will diso tend to steer stoms through the area, as a iscussed by crane (1978), and therefore coula be an area for 



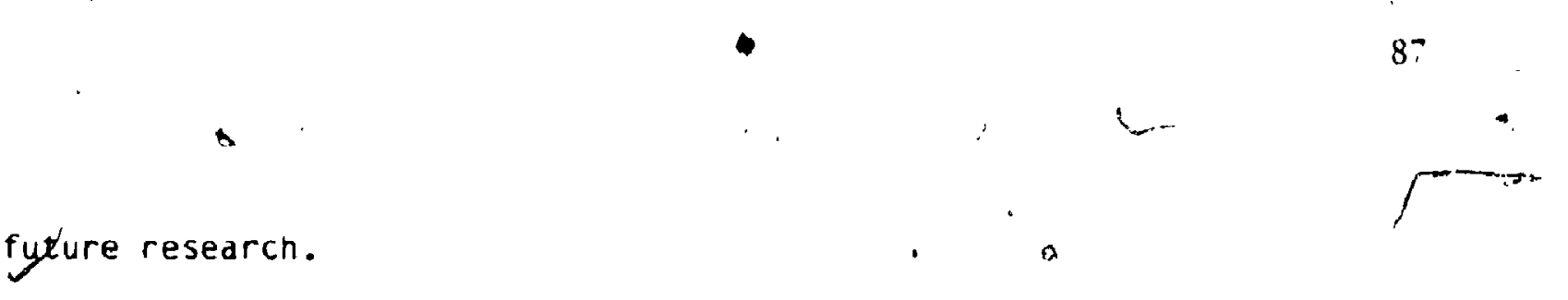

The february prevailing wind data did not show any significant relationship with the variation in ice extent. Symonds (1984) indicates that a combination of increased wind speed and cold temperature creates conditions more conducive to ice férmation. Although temperature and wind are somewhat interdependent, Markham (1976) points out that westerly winds may be cold or mild depending on their upwind source. Therefore higher terly wind speeds may not necesarily correspond with the colder temperatures which would result in increased ice fotmation. Thus the relationship between westerly wind speed and ice extent is not a direct one.

From these comparisons, it seems that air temperature (seasonal and accumulated freezing degree days) and water temperature variation patterns exhibit the clearest and most unambiguous relationship with the ice extent and area interannual variability. The Icelandic low position is known to exert a controlling influence over the ice season (Markham, 1976), but a close relationship with ice extent has not been observed in. this analysis. The climatological and oceanographic pardineters examined are interrelated in "one way or another, through atmosphere-ocean interaction processes. Therefore. it is not possible to define one controlling mechanism of maximum ice extent along the Eastern Canadian Seaboard. It' can only be concluded, that during the 1973 to 1985 time pertod, yedrs of extreme maximum ice extent corresponded to extremes in winter ; seasonal air temperature values and accumulations of freezing degree 
days, and positive and negative sea surface temperature anomalies.

\subsection{Regional Maximum Ice Extent Analysis}

I'h examining the Eastern Canadian Seaboard as a whole, trends in maximum ice extent in the individual subregions may be masked. The maximum extent does not necessarily occur at the same time in all regions, nor does it usually correspond to the maximum extent for the Eastern Canagdian Seaboard as a whole. For example, in February 1985 the pack ice was so extensive inthe East Newfound and waters that five drilling rigs had to be moved off location and arilling operations were suspended for many weeks (Eastern Offshore News, 1985). The Eastern Canadian Sedboard maximum jce area and extent values for 1985 are not abnormally high. Therefore the extensive conditions of the East Newfoundland waters are hidden by the contributions of the other subregions, where conditions were normal. Since offshore operations tend to cluster in specific regions of the Eastern Seaboard, it is of. interest to examine the maximum ice extent trends for its four main subregions, namely Davis Strait, Labrador Sea, East Newfoundland Waters; and the Gulf of St. Lawrence. The boundaries of these subregions are defined in Figure 3.1 .

The maximum ice extent and area values fol the individual subregions are derived according to the methodology described in chapter 4 (Section 4.4.3.1). For this analysis SMMR data is used, covering the years 1979 to 1985, because of the ease'and consistency of computer generation of statistics. Figure 5.8 graphically displays the maximum 
FIGURE 5.8

Eastern Canadian Seaboard Regianal Trends in Maximum Ice Extent - and Ice Area (1979-1985)

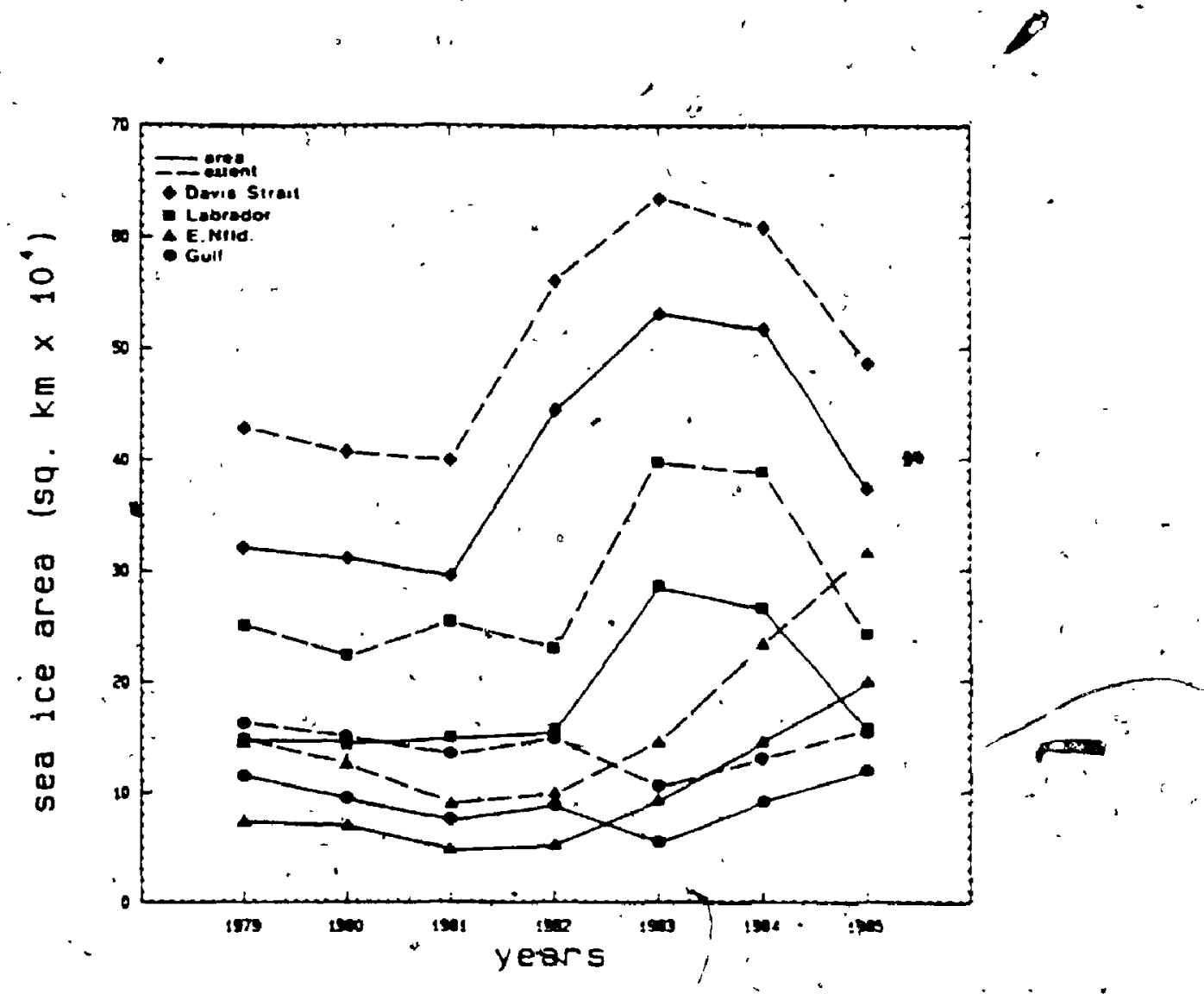




\section{.}

90

ice area and extent values. for the defines subregions, producing curves of trends over time. 'Table 5.7 lists the specific values, with maxima and minima for the 1979-1985 period highlighted. By examining the trends produced, one can see how individual regions vary as compared one another. -

An initial examination of the curves in figure 5.8 reveals that the Davis Ștrait and Laprador Sea regions exhibit simila patterns in maximum ice extent. The East Newfoundland waters and the Gulf of st. bawrence regions also exhibit similar trenos. Maximum extent for the

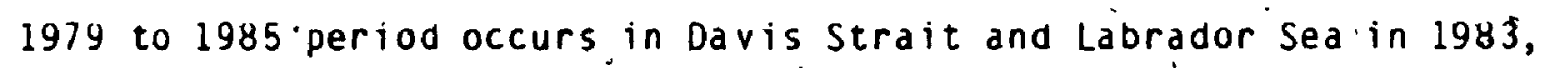
while the East Newfoundland Waters and Gulf show maximums in 1985.

0 Therefore, the two southern jons exhibit maximum conditions approximately 2 years after the northern regions. Minimum conditions persist in al 1 regions from 1979 to 1981, which corresponds to minimum conditions seen in the Eastern Canadian Seaboard trends. The increasing trend starts in Davis Strait after 1981, in the Labrador Sea after 1982," in the East Newfound and Waters after 1982, and in the Gulf of St. Lawrence after 1983 . Thus there appears to be a delayed reaction as one progresses southwards along the Eastern Seaboard.

The trends (1979-1985) observed in the indiyidual regions suggest possible areas of future research. The similarities in trends between the Davis Strait and Labrador regions and the East Newfoundland and Gulf regtans may be due to similarities in ocean current patterns, and thus warradts further' research. The time lag present in the maximum ice : extept from north to south indicates that it may be possible to predict 


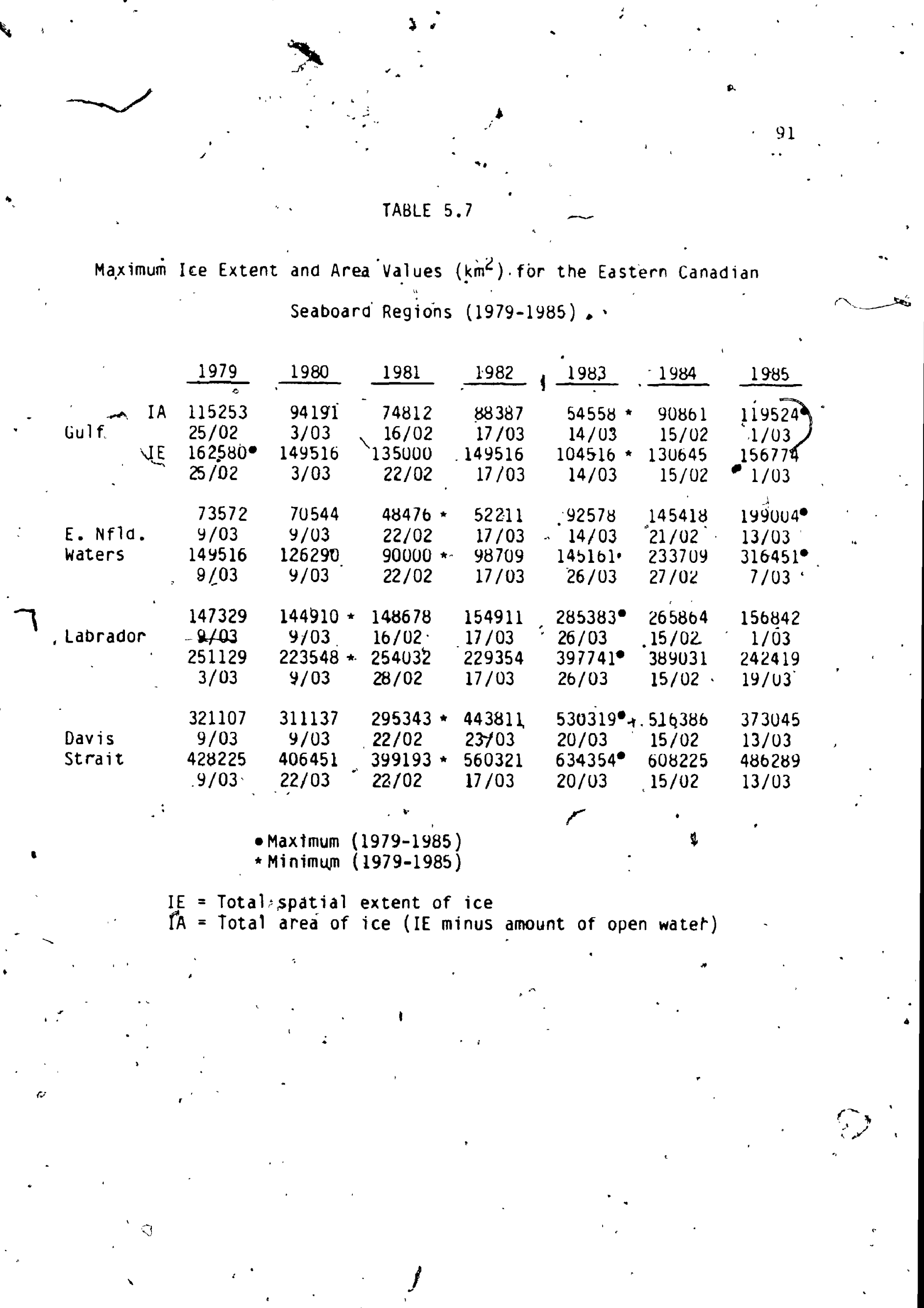


above normal maximum ice extet by monitoring northern conditions. In order to derive any significant relationship, a much. larger dat set would need to be examined, longer than the available passive microwave data set. The patterns indicated in the analysed portion of the passive microwave data set do warrant further "research, on the way to achieving the ability. to predict extreme maximum ice extent in regions of heavy offshore activity, i.e., the East Newfoundland Waters.

\subsection{Climatic Significance of Maximum Ice Extent Trends}

The 13-year archive of passive. microwave data is considered brief in tems of climatic studiest Investigations of climatic change require many decades of data in order to derive significant trends. If the passive microwave ice information is combined with historical ice information, such as Atmospheric Environment Sefvice ice charts, general trends can be derived. The main drawback of using historical data is the inconsistency of information coverage. Many remote regions are not monitored on a continuous basis due to the high costs of aircraft reconnaissance. Therefore the amount of ice information available is itimited.

Markham (1980) presents median, maximum and minimum ice extents from AES ice charts for the 1963 to 1973 decäde covering the Eastern Canadian Seaboard. The, combination of this information with the passive microwave ice information extends the available data set to 22 years. Shus there, is the potential to derive more significant climatic trends. Unfortunately there are drawbacks to using the Markham (1980) 


6.1 Summary of the Interannual Variability Analysis

Maximum ice extent along the Eastern Canadian Seaboard is a parameter of much interannual variabifity. The analysis bef maximum ice extent and area trends derivea from passivemicrowave satel lite data yields significant results towards a better understanding of ice conditions in the Eastern offshore regions. Although one definite controlling mechanism of maximum extent was not identified, the correlations of maximum ice extent g̨nd"area trends to trends in seasonal air temperature, accumulated freezing degree days, and sea surface temperature are significant. Thus, the objective of accounting for the observed maximum ice extent interannual variability from 1973 to 1985 is achieved. The róle of atmospheric circulation bears further research, especially, in i ight of the need for a greater understanding of the atmosphere-iceocean interaction.

The passive microwave satel lite data set avallable is an important source of information on global, hemispheric and regjonal ice condi. tions: The consistency and complete glcbal coverage of the data set ensures an excellent source of information concerning ice conditions in remote regions. The methodology applied to the Easteru Canadian 
Seaboard can be applied to any other ice region, as large as the whole Arctic or as small as the Gulf of St. Lawrence. Interannual variability in ice conditions can be studied both quantitatively and qualitatively with the available data set. Even though the resolution of the data is coarse $(30 \mathrm{~km})$, the data set offers many advantages over traditional ice charts based on aerial reconnaissance, such as those produced by the Atmospheric Environment Service. Ice charts are generally praduced on a regional basis and limited to certain times of the year. For example, north of $55^{\circ} \mathrm{N}$ ice intormation is generally not available during the. winter months at the time of maximum ice extent. Passive microwave satellite data is available continuously for all regions of interest.

6.2 Limitations of Methods apd Data

The climatologica.t and oceanographic data available for the Eastern Canadian Seaboara is I imited to coastal meteorological stations and oceanographic stations. The spatial distribution of these stations is not consistent over the area, which creates problems in deriving rèpresentative means for the study area as a whole. Ideally, the resolution of the climatological and oceanographic data should equal that of the cal rected microwave data to form a representative picture of conditions over the whole area. Despite this limitation, the climatological and oceanographic data used in, the comparisons of Chapter 5 yielded rel iable results. For the purposes, of this research, the data used was therefore sufficient.

The resolution of the passive microwave data. is 1 injted to $30 \mathrm{~km}$, 
which is censidered coarse in tems of satellite data. For analysis of ice conditions on a iarge regtonal basis, such as the Eastern Canadian Seaboard, the resolution is not a limitation. As indicated previously, ice edge positions can be determined to an accuracy of $\pm 15 \mathrm{~km}$. For studying ice extent variation on an annual basis, this accuracy is sufficient.

\subsection{Implications for the Canadian Offshore Scenario}

Wintertime of fhore activity along the Eastern Canadian Seaboard is dependent upon the severity of ice conditions. The optimal yoal in sea ice research would be to achieve the ability to predict extremes in ice extent, in orger to plan offshore activities accordingly. Wadhans arid Lever (1985) indicate that improved forecasting of ice extent and concentration would improve the efficiency of all types of marine operations, especially in of shore Newfound and and Labrador. The results of the interannual variability analysis provide a significant contribution to the understanding of maximum ice extent within the regions of interest. The trends abserved in the individual subregions suggest that tpe time-iag. in the ice extent relationship. between northern and.

+ southern regions is an area needing future research, on. the way to achieving the ability to predict extremes in ife extent the monftoring of seasonal (winter) air temperatures and sea surface temperatures may give insight into the degree of maximum ice extent that will be attaimed sin a winter season. Ine optimal goal would be to define predictors that could. be monitored previous to the jce season, in the fall time period.. 


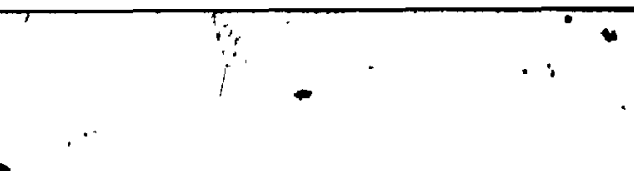

98

\subsection{Applications to Climate Research}

Climate variability is an important area of research" today within the scientific community. The role of sea ice interagival variability as.an indicator of climate variability has been emphasized by many 'scientists (e.9., Maykut, 19.78; Crane, 1981; Zwally, 1984). Passive microwave satel lite data can be a useful source of ice concentration and extent information needed in climatic research endeavours. Comiso and Zwal iy (1984) indicate that even though the resolution of the data is" limited $(\sim 30 \mathrm{~km})$, spatial and temporal detail can be derived, and overa 11 conditions of sea ice cover can be statistically analysed. The ice concentrations and ice area values derived from the satel"lite data can be usej as input in various climate models investigating the atmosphere-ice-ocean processes. The satellite platform provides nearglobal coverage not available with traditional methods of ice reconnaissance. Therefore, for any one region a consistent sea ice data setris availabla in the passive microwave satel lite data base. The digital format of -the data al lows for a variety of quantitative analyses to be performed using computers. Thus; detailed analyses of climate-sea ice interactions are posstble, with comparisons of ice concentration and extent statistics to computer-based digital climate data sets. The climatólogical and oceanographic comparisons.detailed in chapter 5 represent simplé examples of the analyses possible with the data set. 


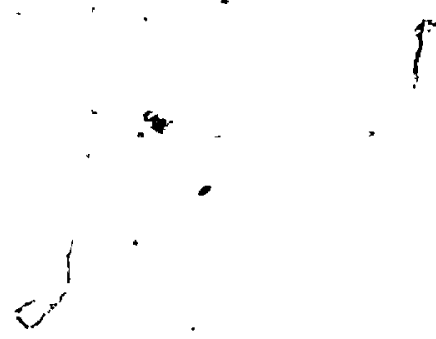

6.5 The Future of Passive Microwave Satell ite Remote Sensing

At: the time of the writing of this thesis, the Nimbus-7 SMMR is still operating beyond its predicted life expectancy. In order to ensure continued data col lection and thus extend the present passive microwave data set, the U.S. Department of Defense is planning to launch the Special Serrsor Microwave Imager (SSMFI) on board its series of DMSP satellites. The SSM/I will provide complete coverage of the polar regions in one day and operate daily (NASA, 1984). With the addition of the $85.5^{\circ} \mathrm{GH}$ channel, the spatial resolution of the data will be reduced to approximately $15 \mathrm{~km}$. The $S S M / I$ performance characteristics are out tined in Table 6.1. At this time, the proposed iaunch date of the SSM/I is between December 1986 and March 1987. When it is 1aunched, the sensor will ensure a passive microwave data set to combine with that of the ESMR and SMMR to cover many decades. The application of this increasedidata set to future sea ice research will be significant, al lowing for more detailed and representative studies of sea ice and climate interaction. This will bring closer the possibility of predicting extreme ice extents along the Eastern Canadian Seaboard. 

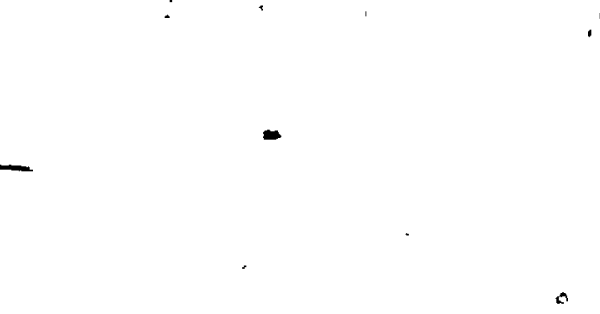

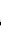
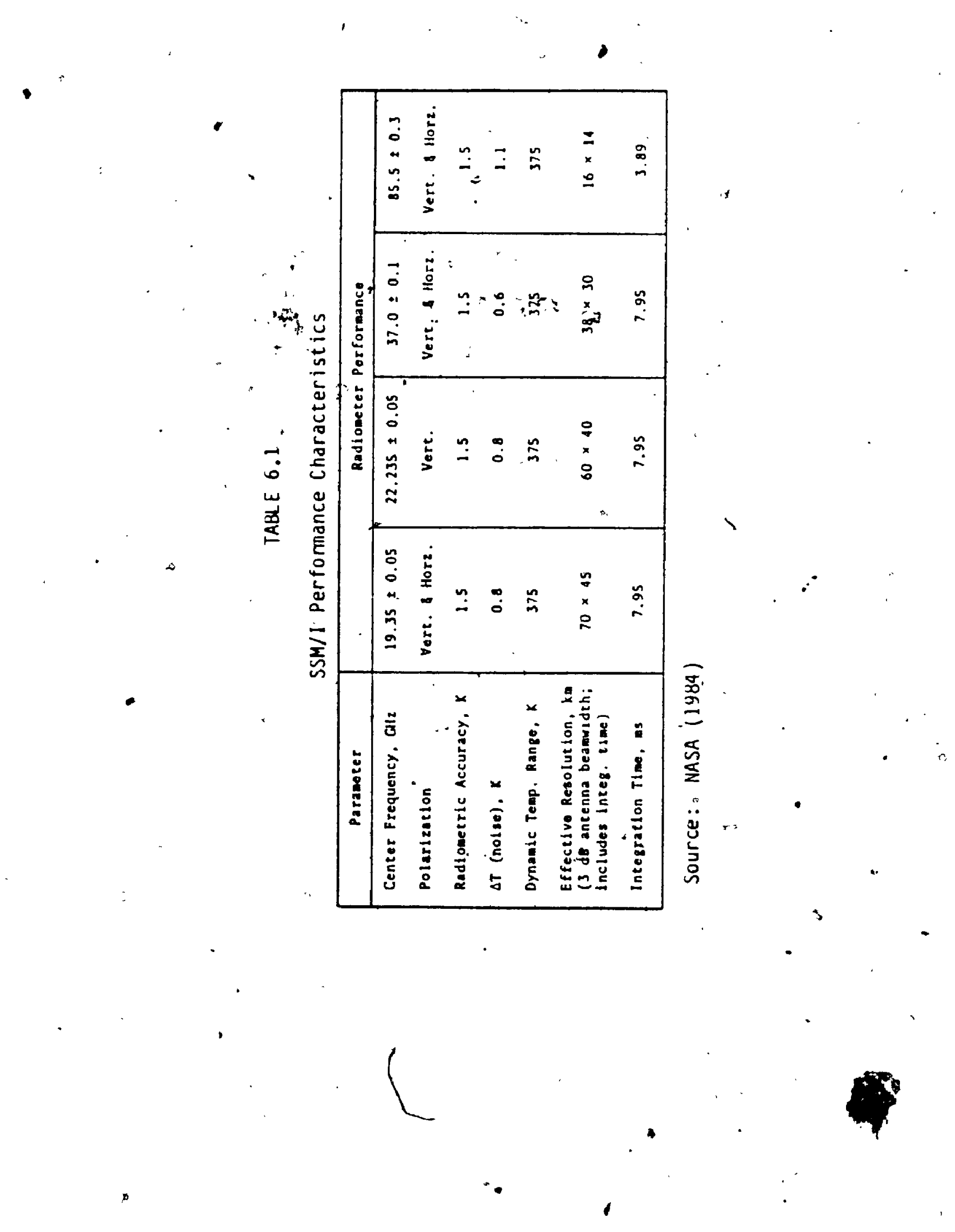

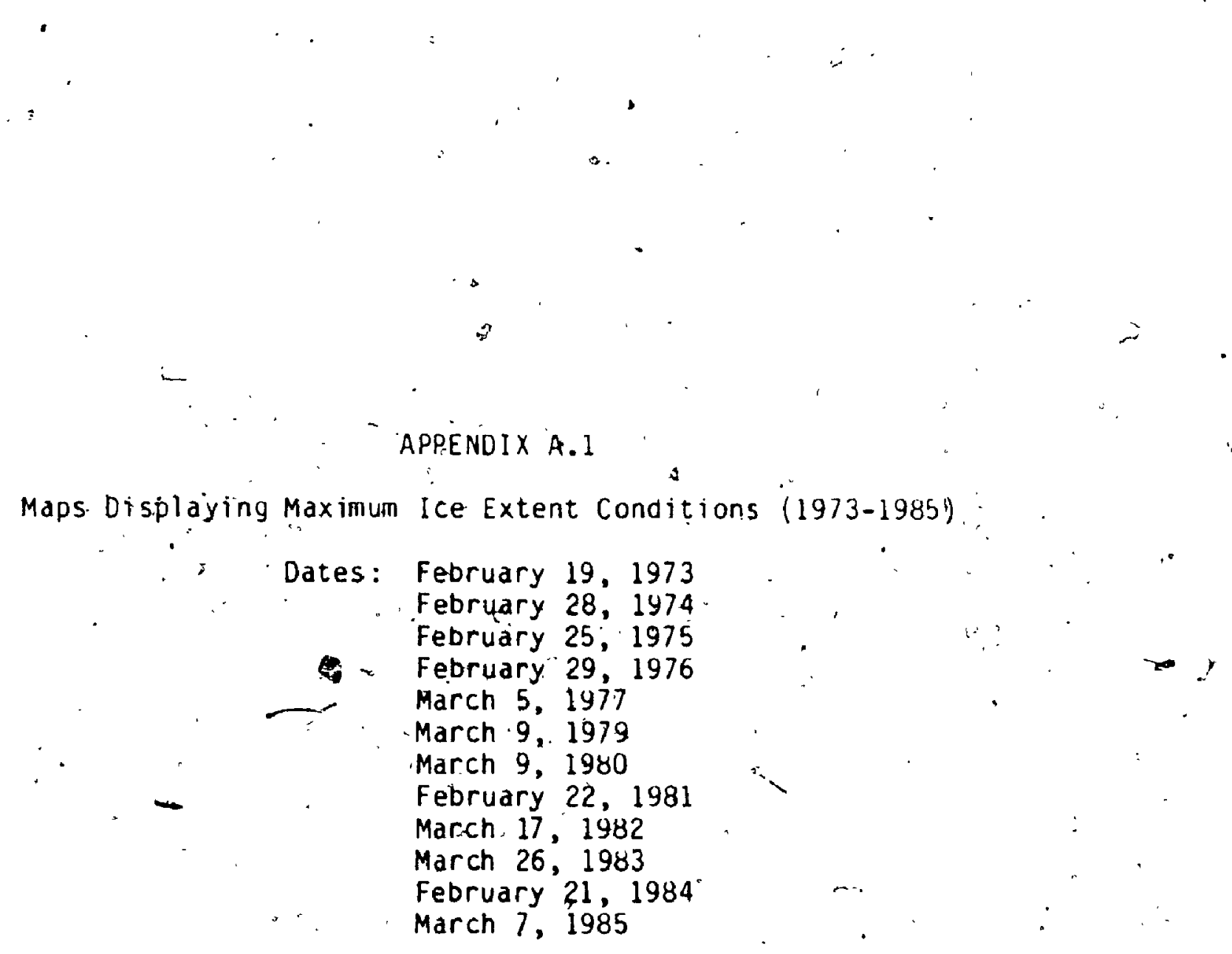

\$.

Note: These maps are reductions of $i: 5,000,000$ mylar maps. The redution process degrades the quality. of the map product somewhat, but maximum ice extent is still discernable by locating the $10 \%$ or $15 \%$ ice concentration contour. 

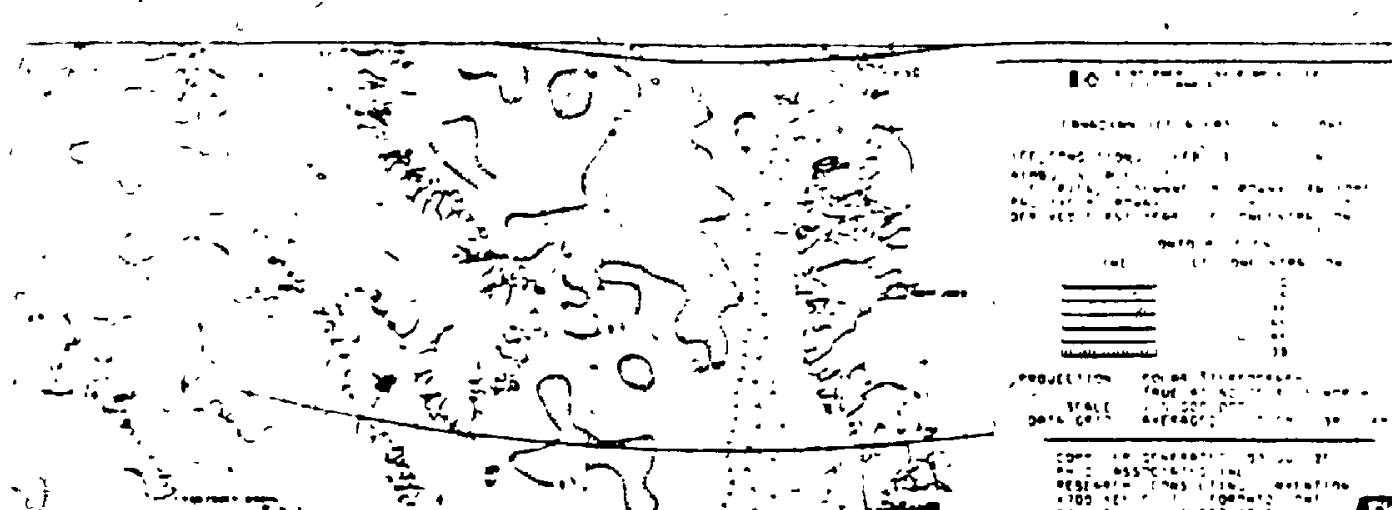

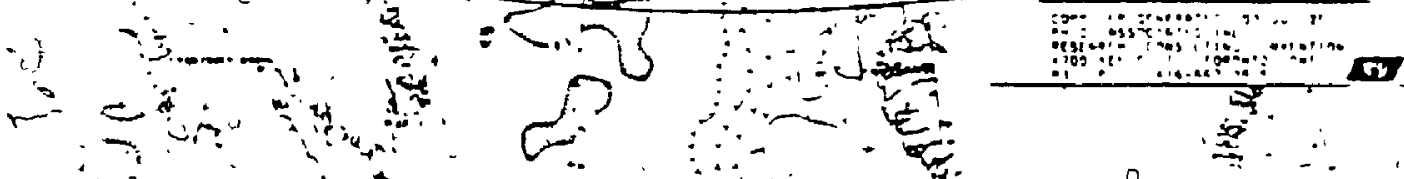

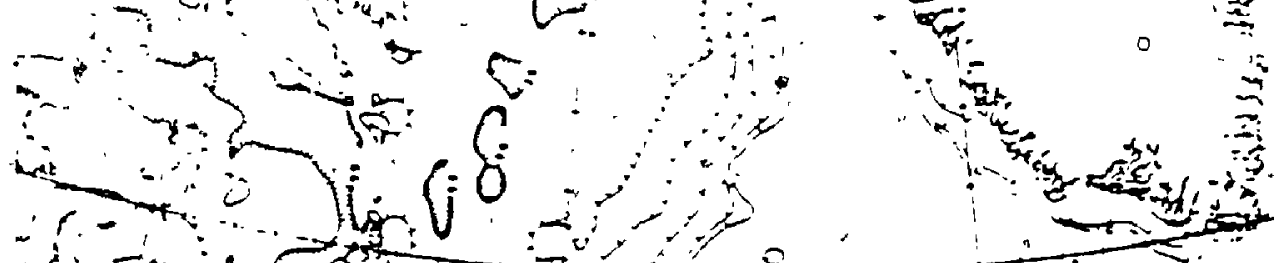

$-10,0$

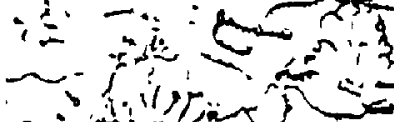

ind

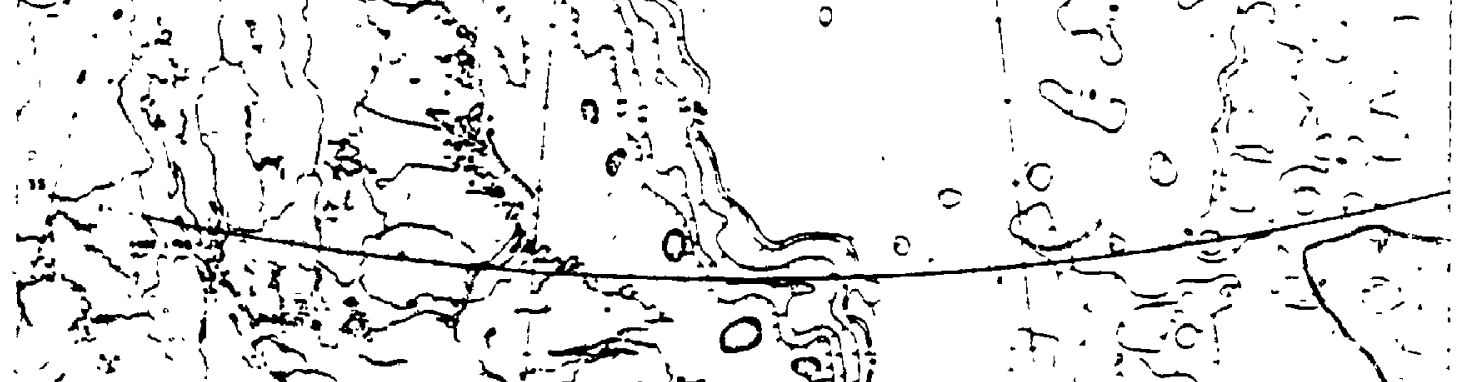

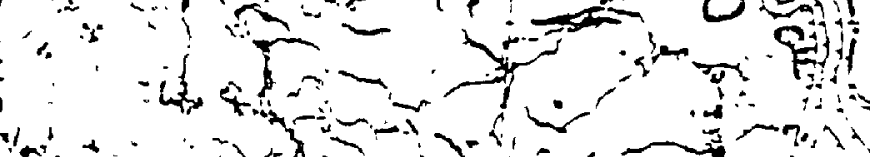

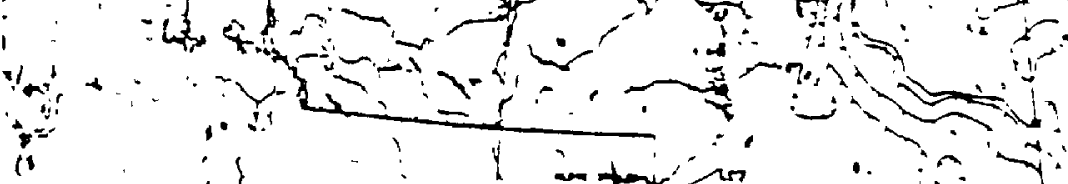

$1-10+20=$

$5-1+4=0$

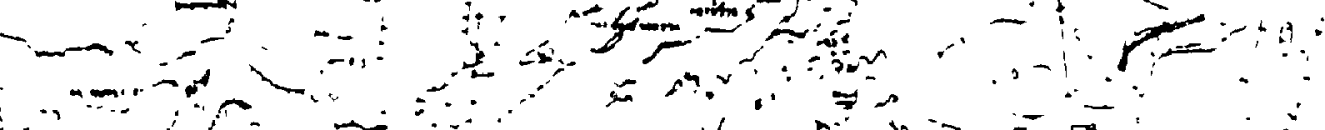

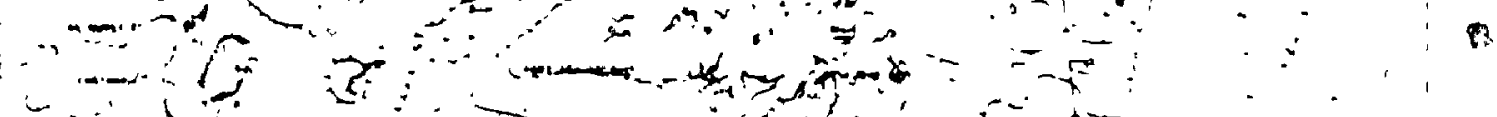

$4,+1$,

3

C..

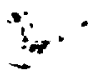




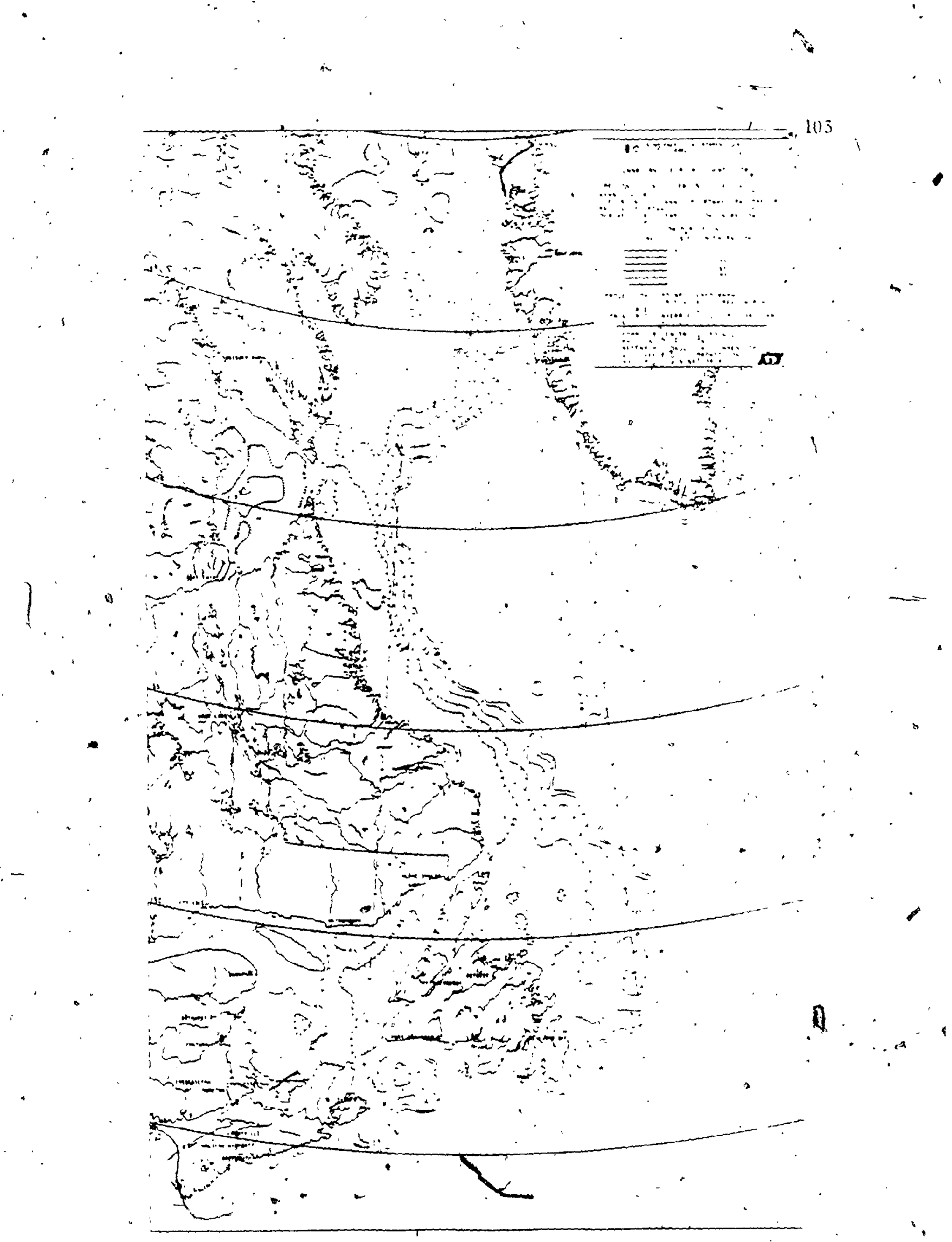


$+2$
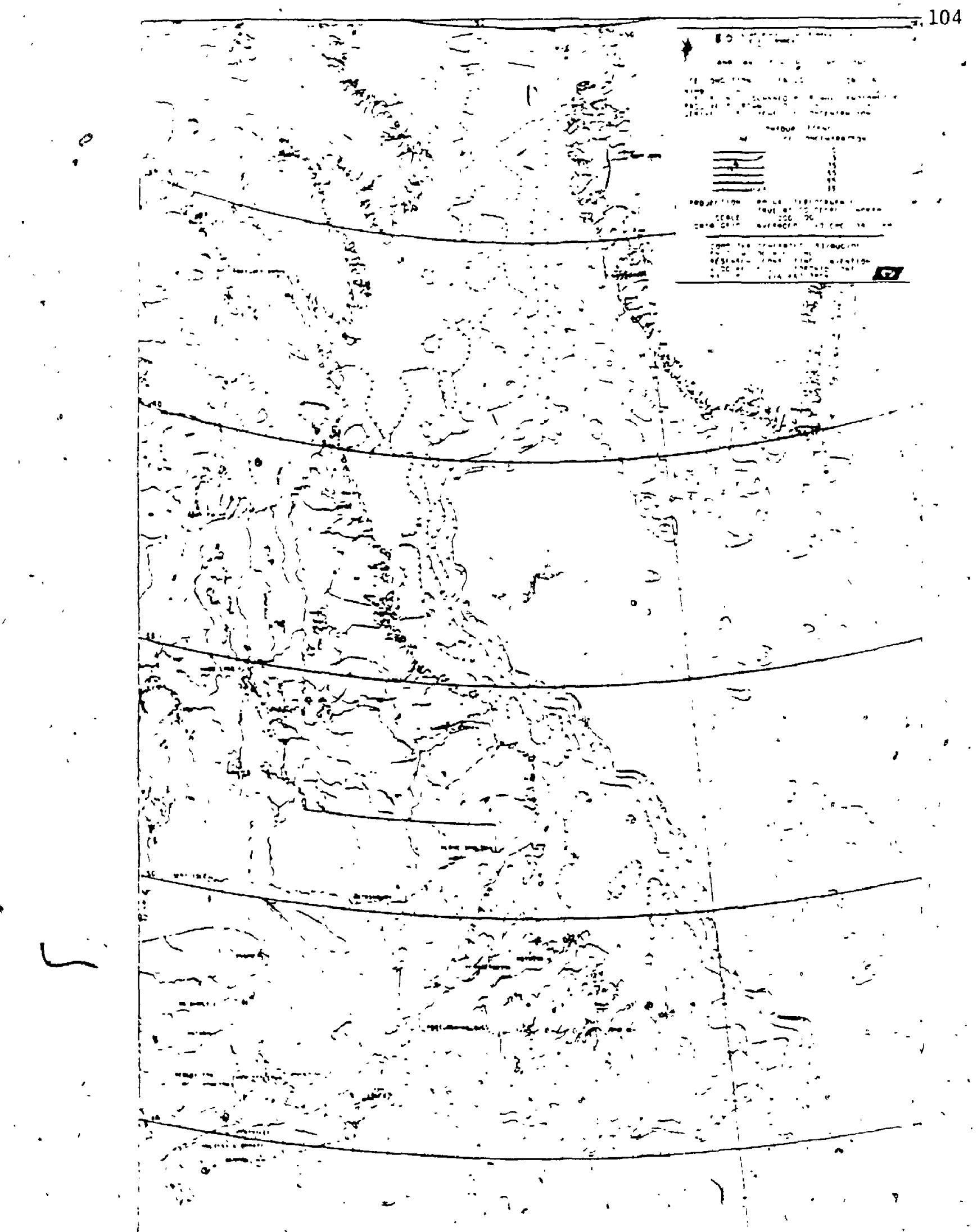

. 


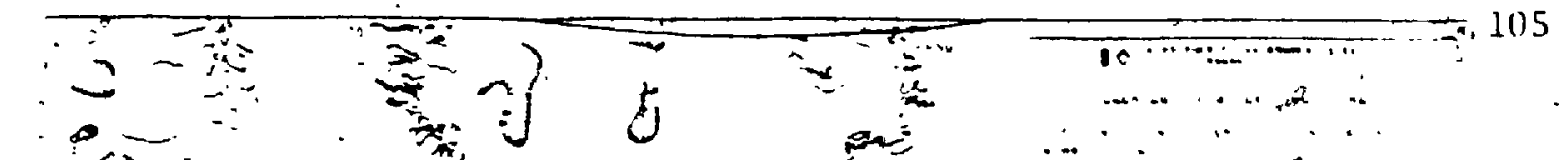

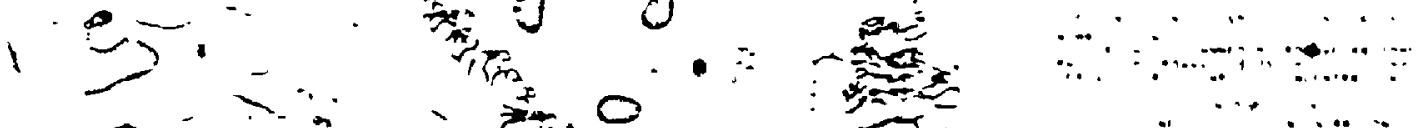

舟,

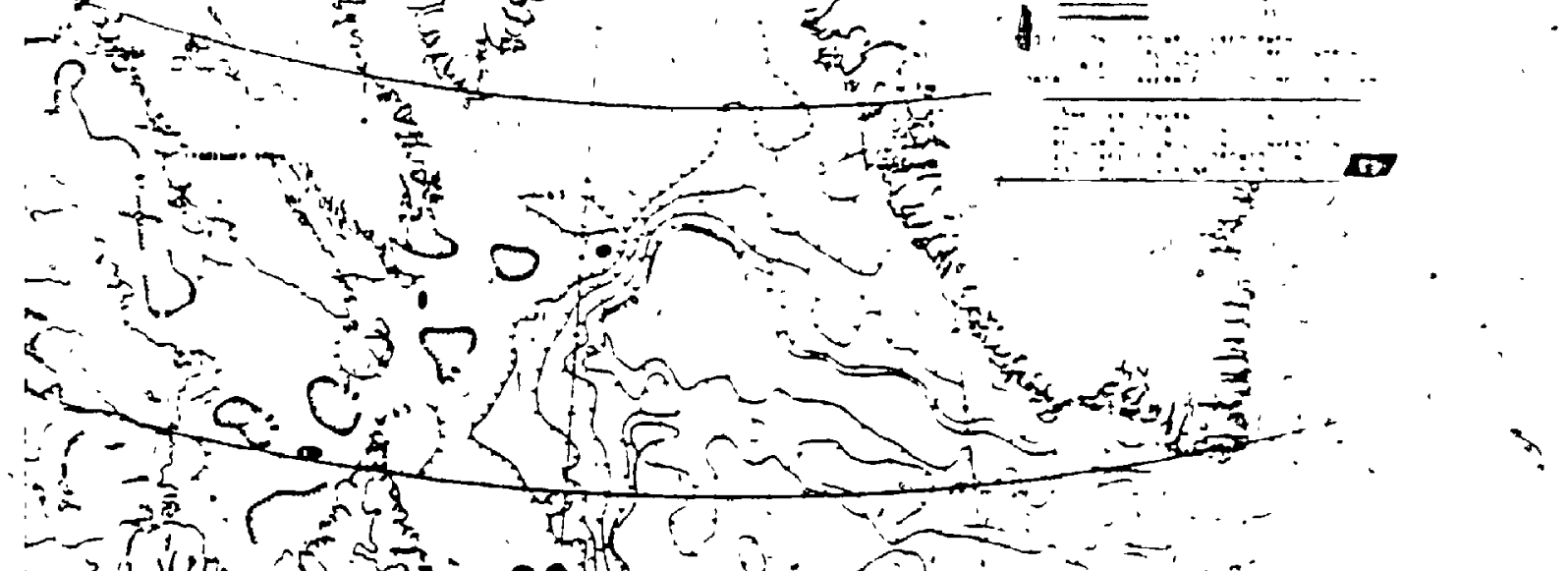

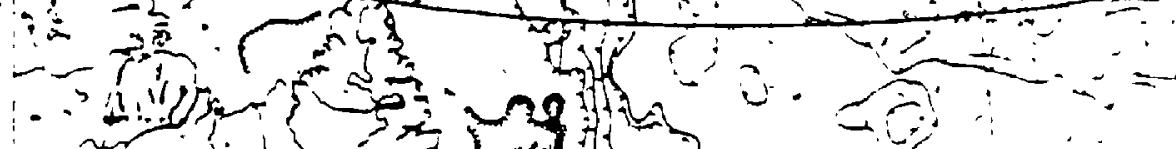

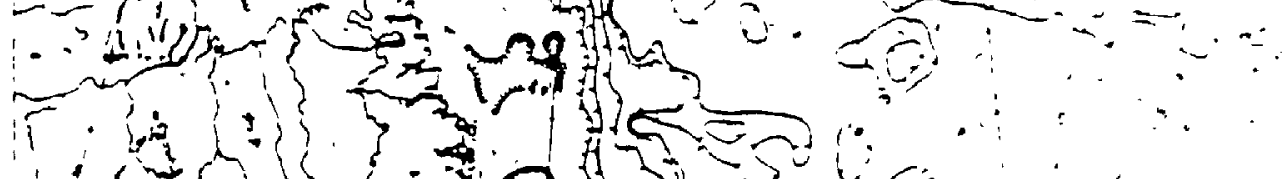

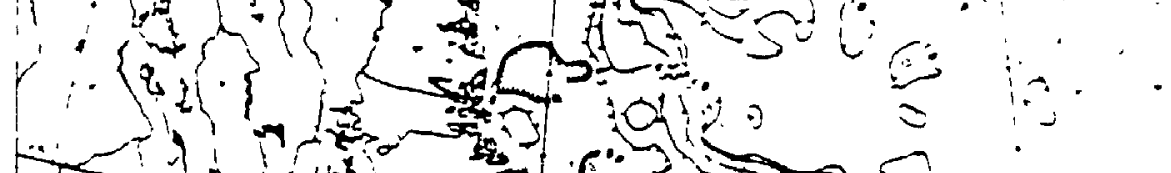

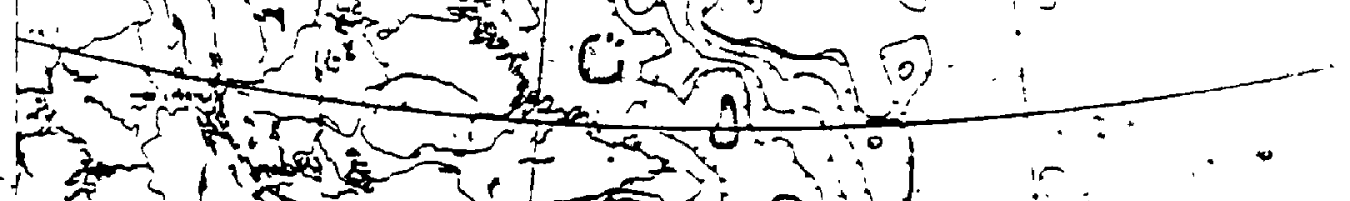

窟
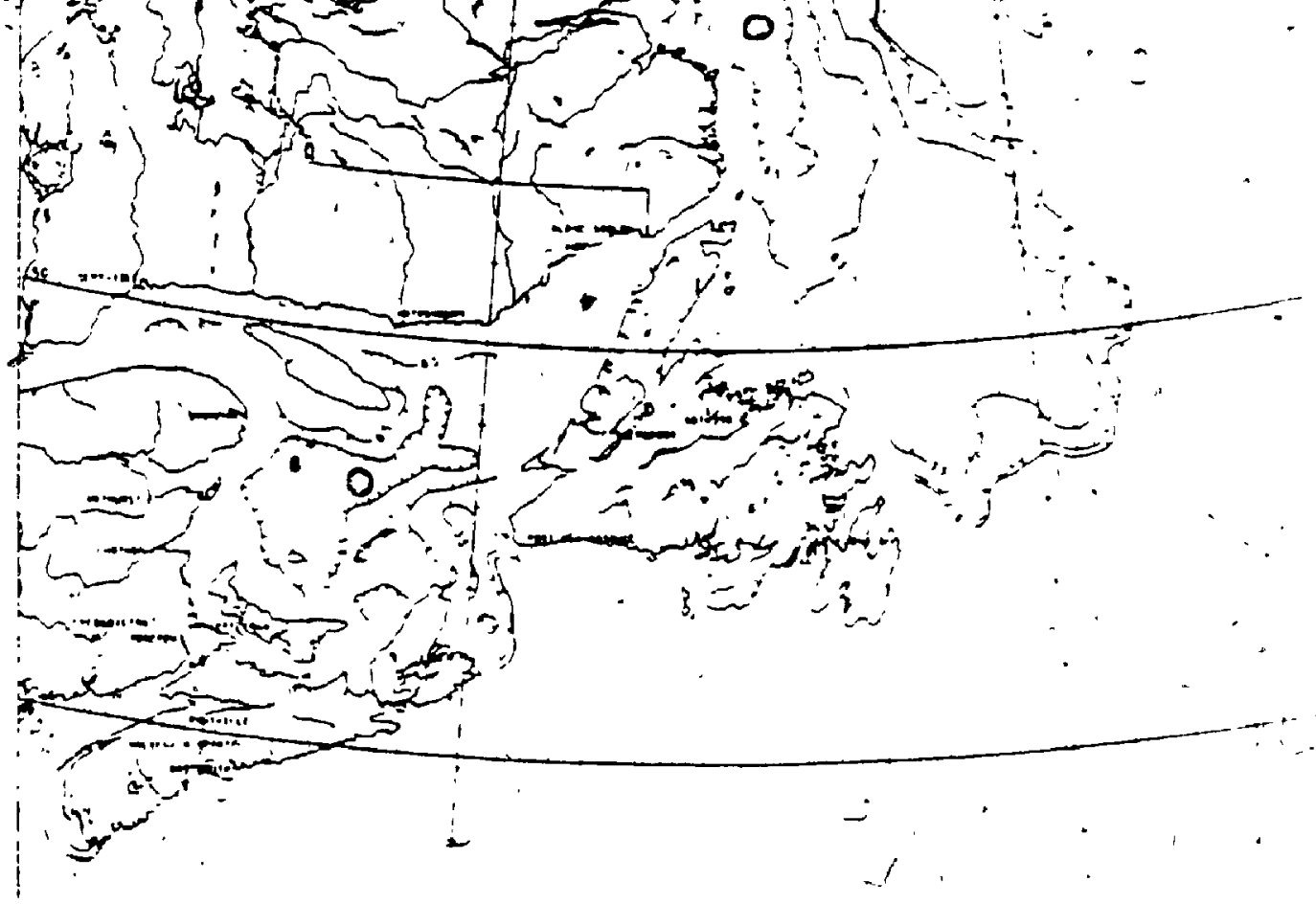


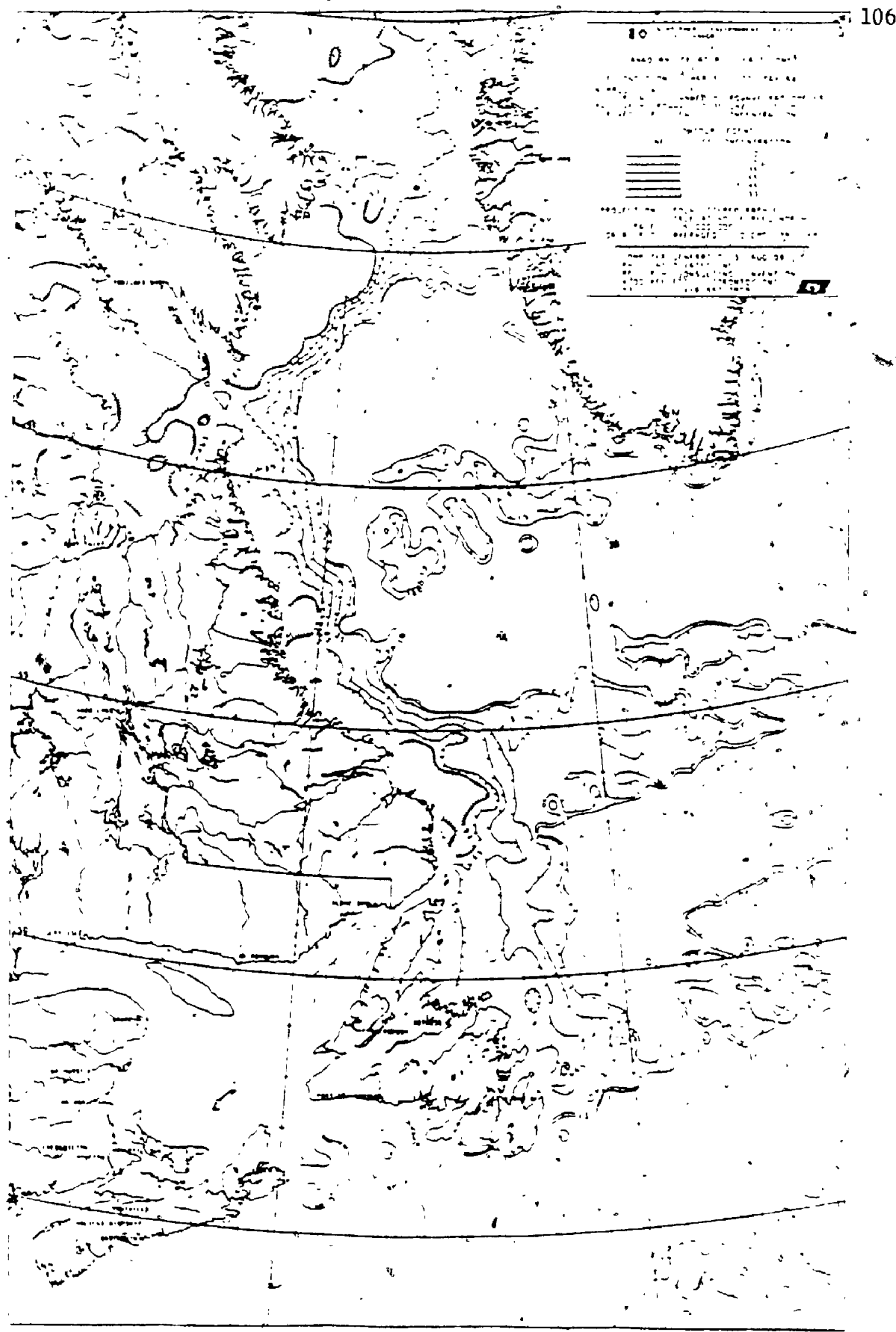




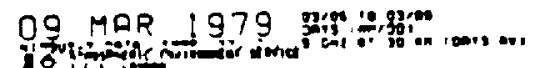

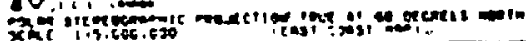

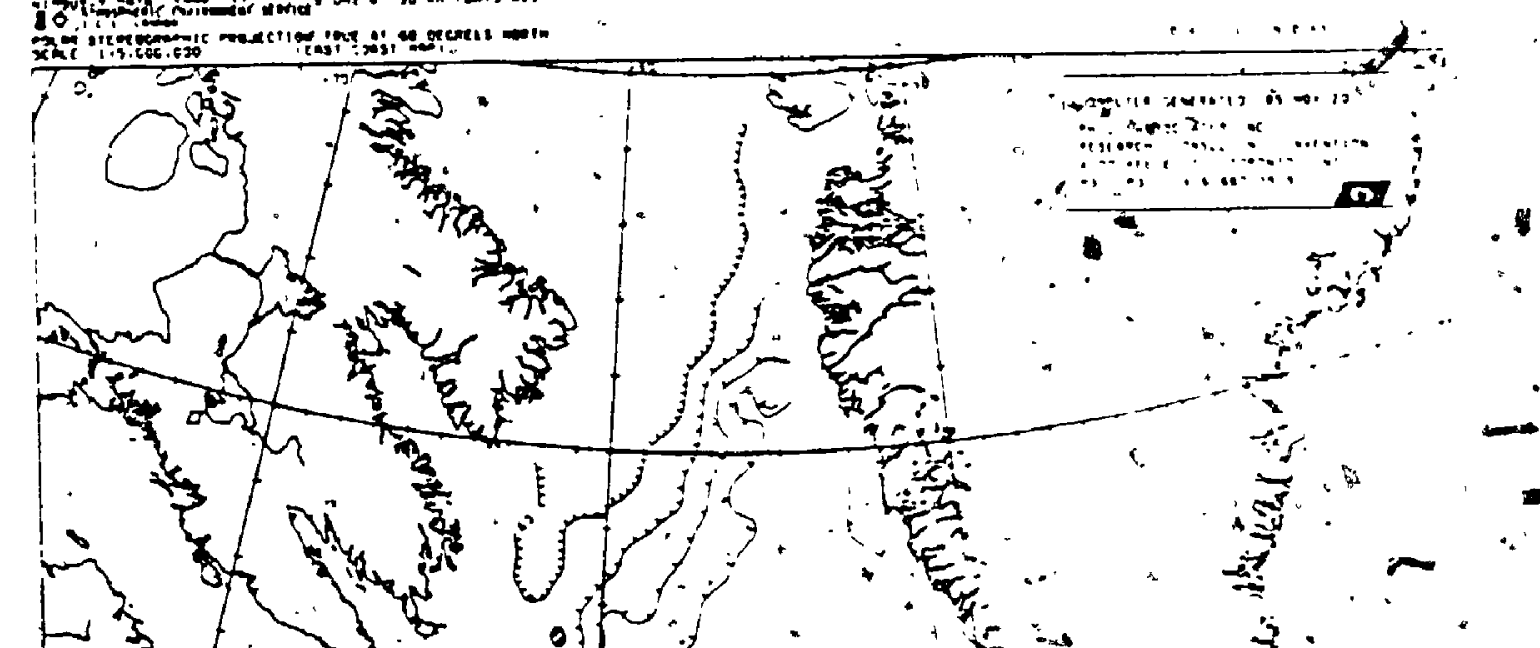

,

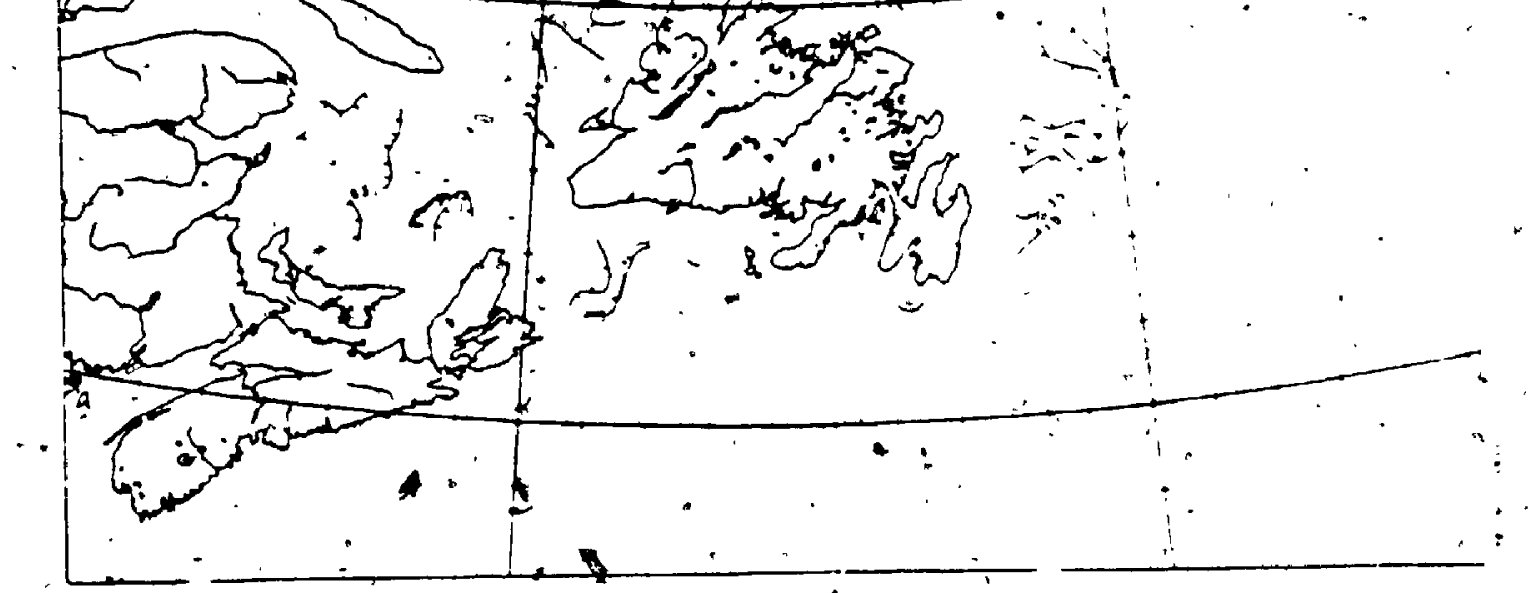




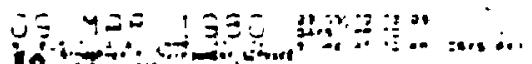

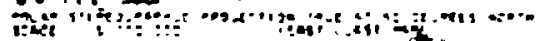
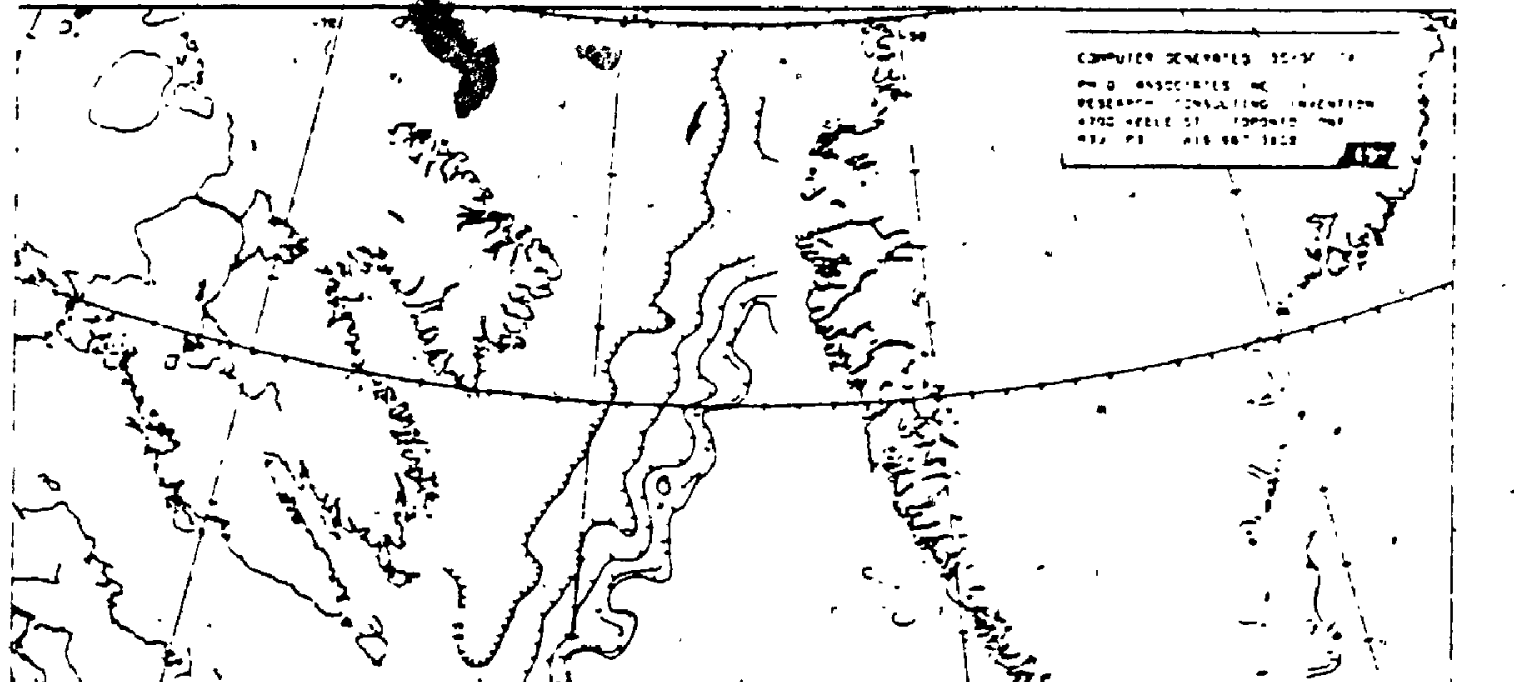

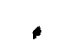




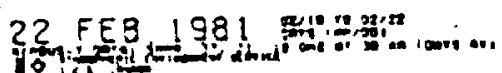

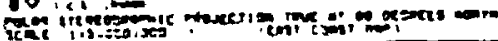

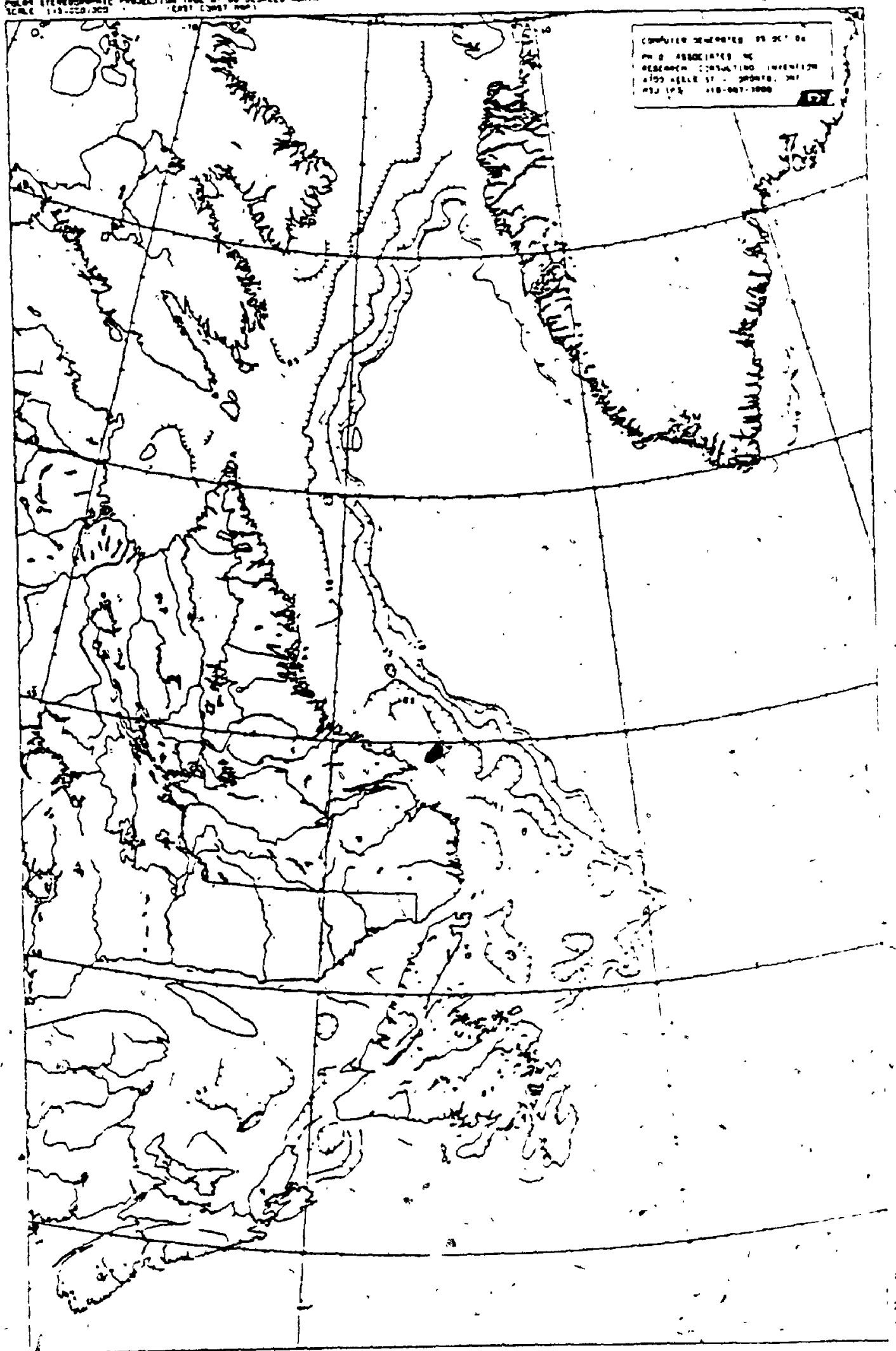

$\rightarrow$ 


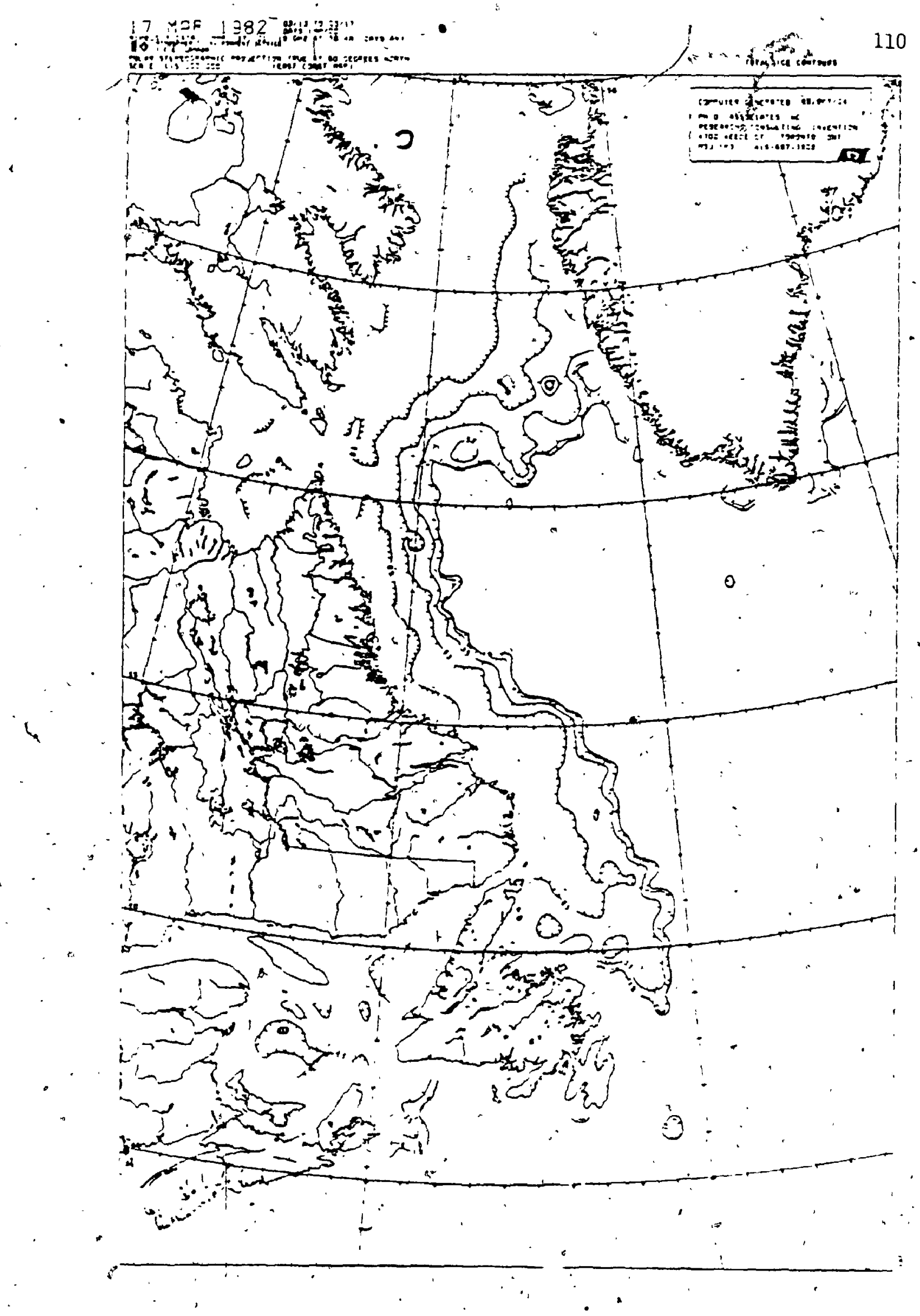


26, M9R 9983 ing.y. $\checkmark$

111

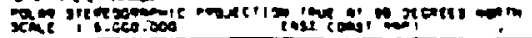
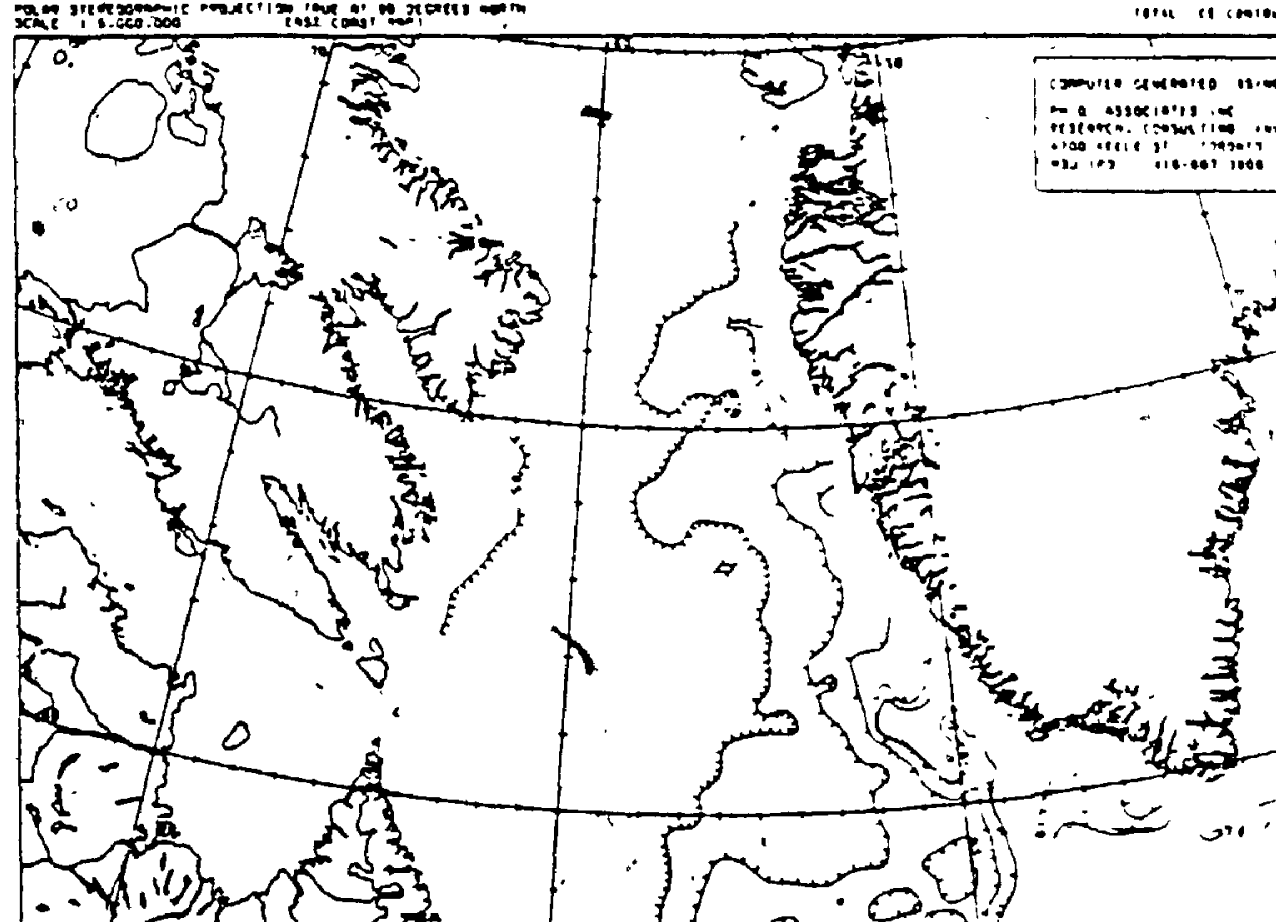
2. FE

ib the

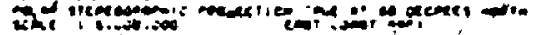

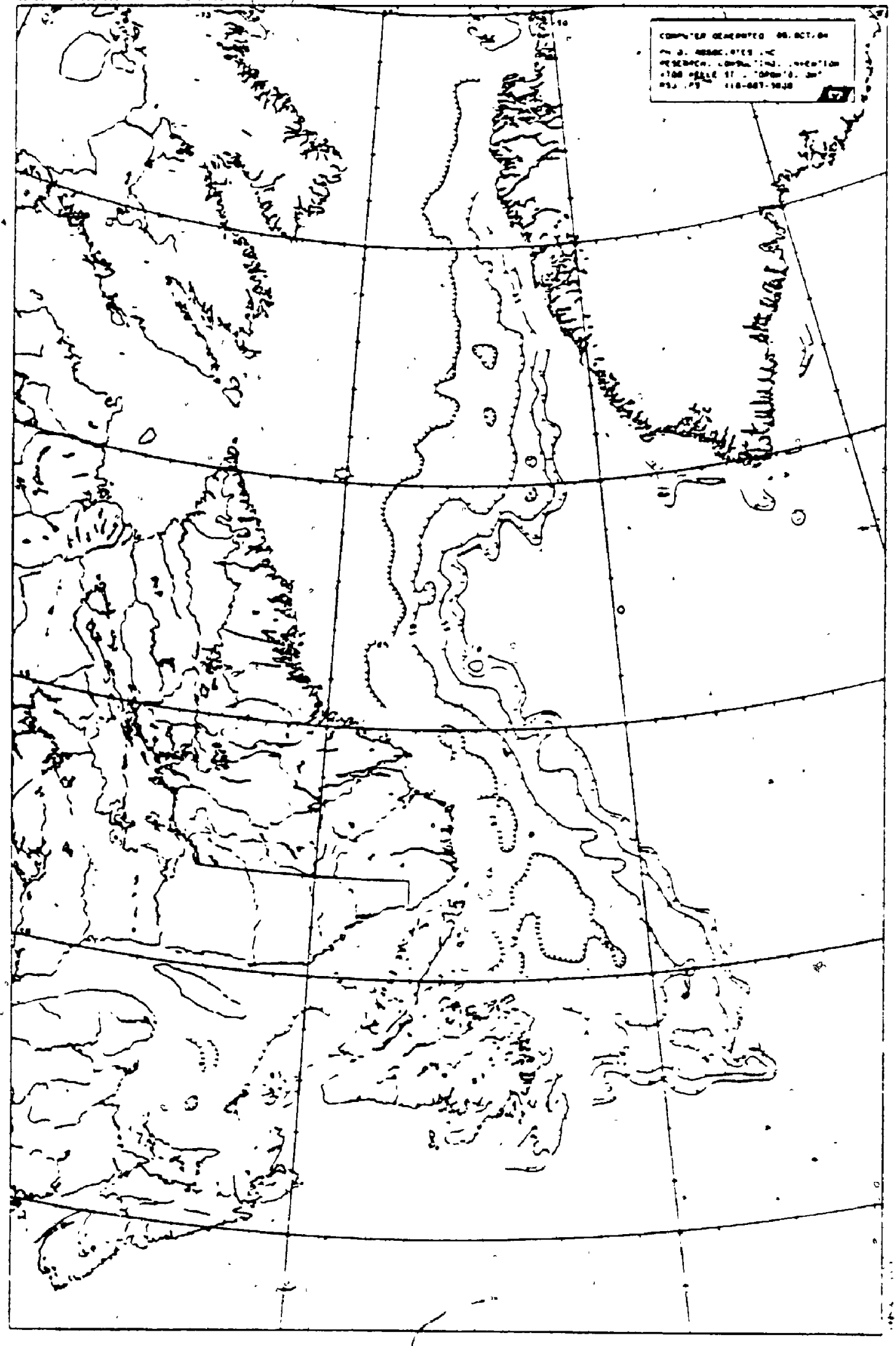




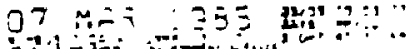

113

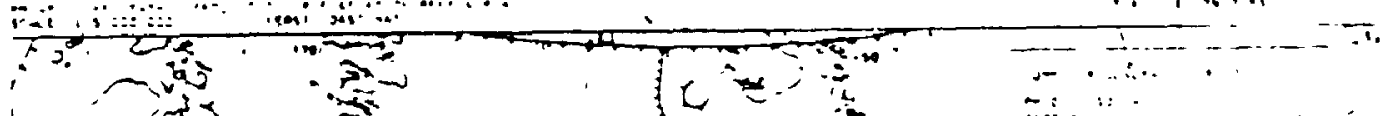
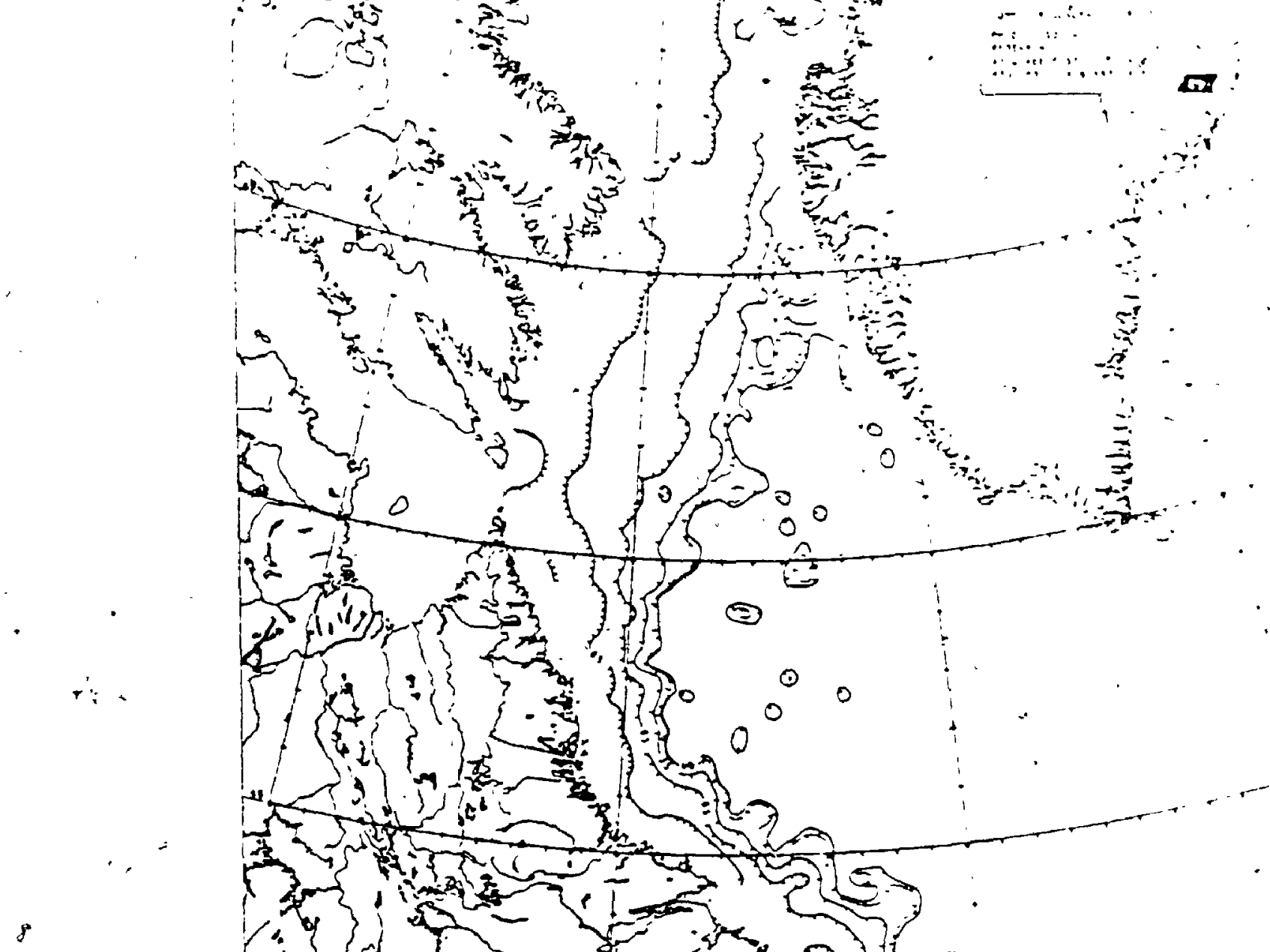

3
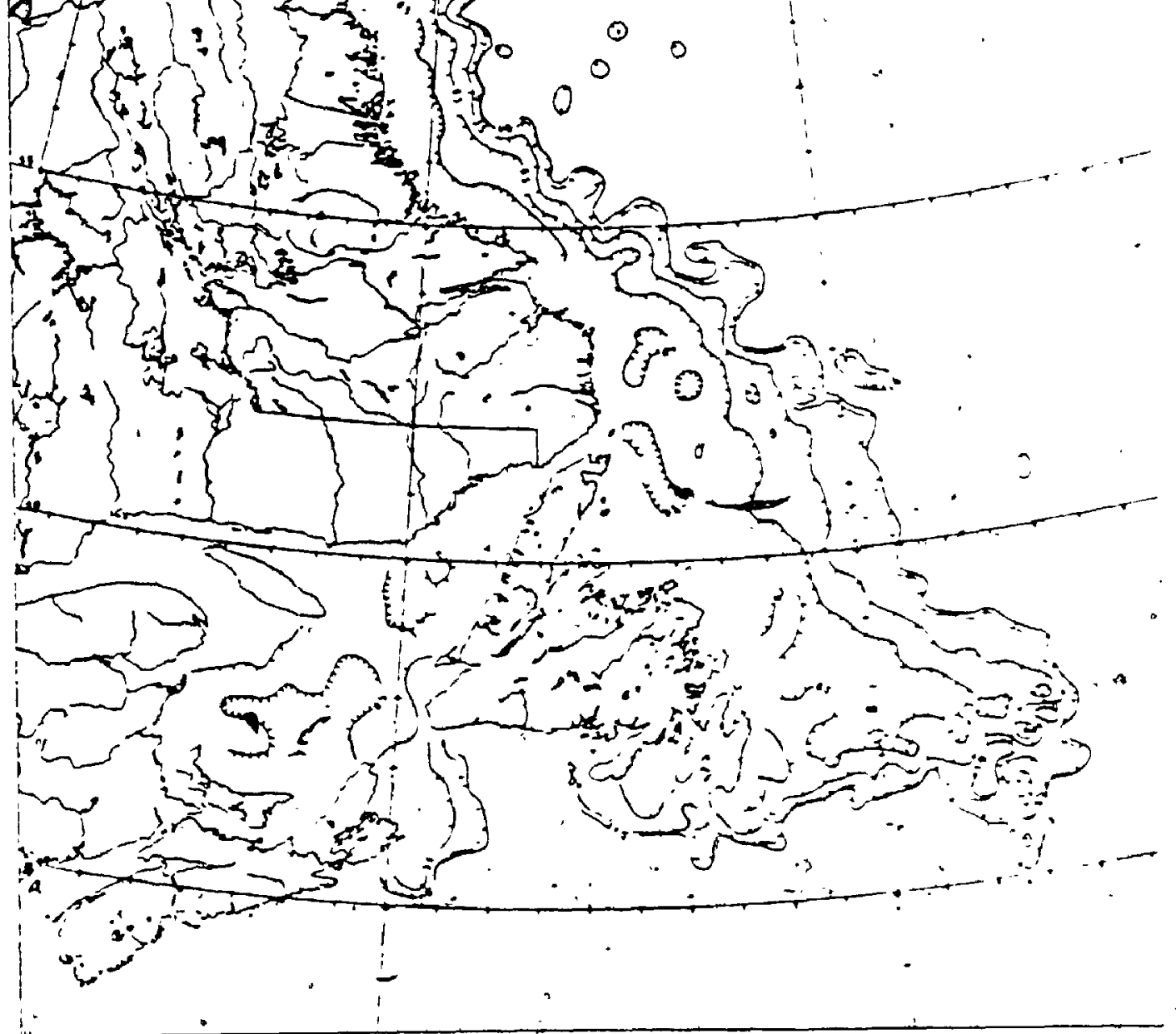
APPENDIX A.2

Ice Area and Extent Statistics (1973-1985)

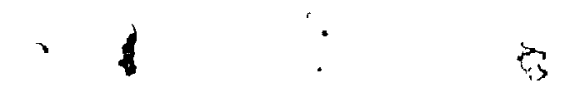




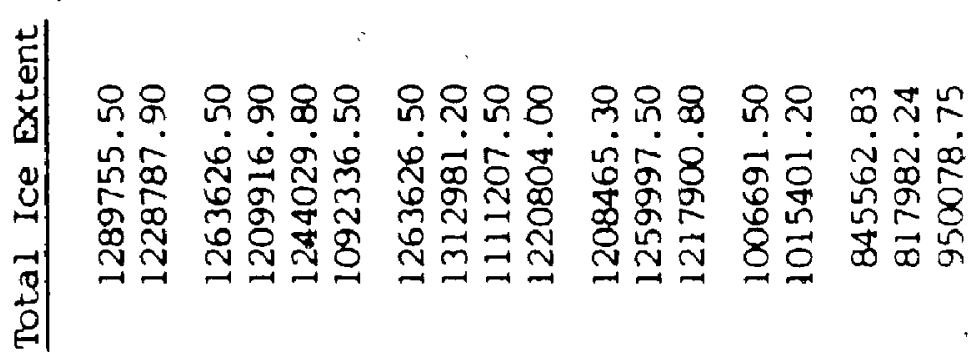

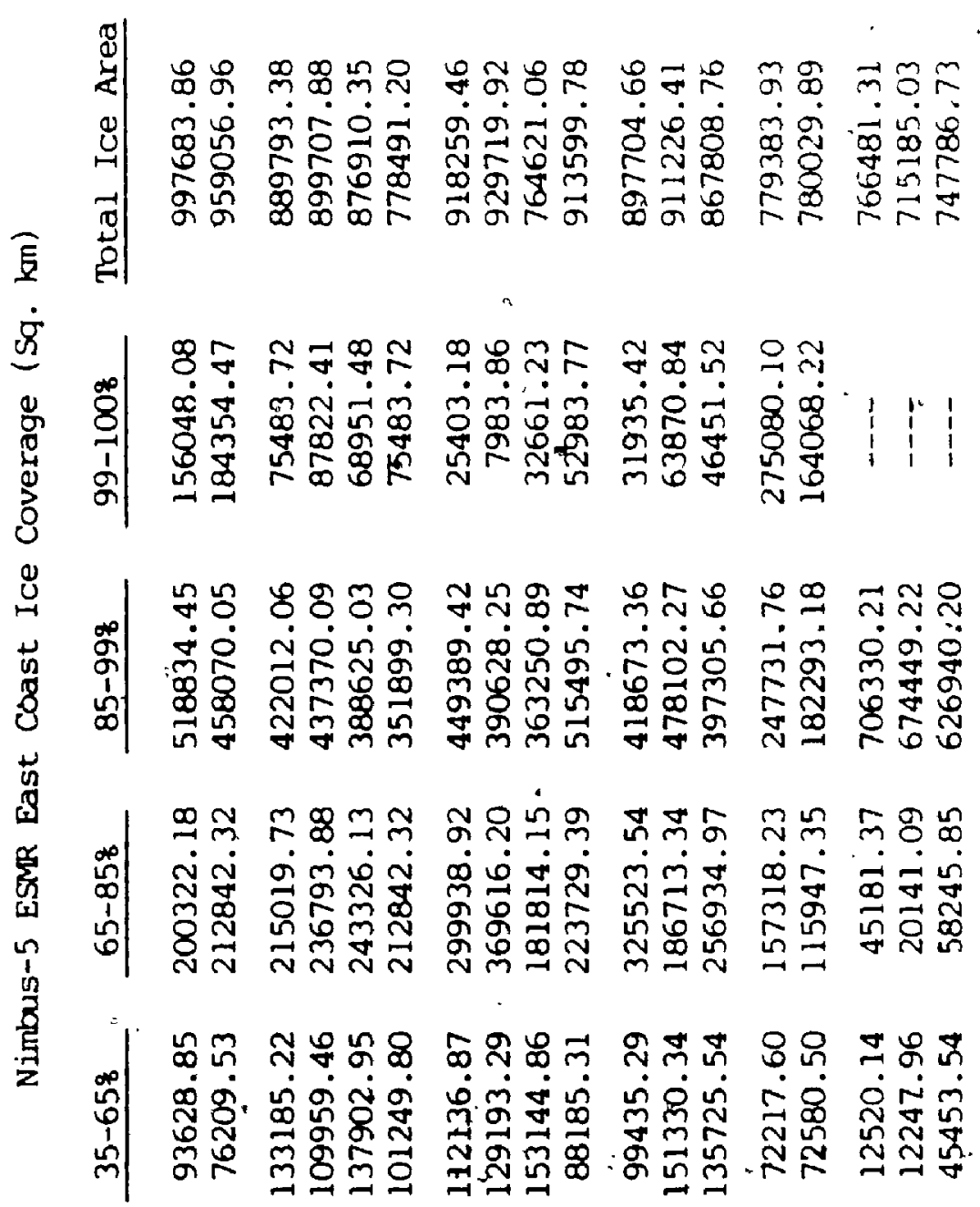

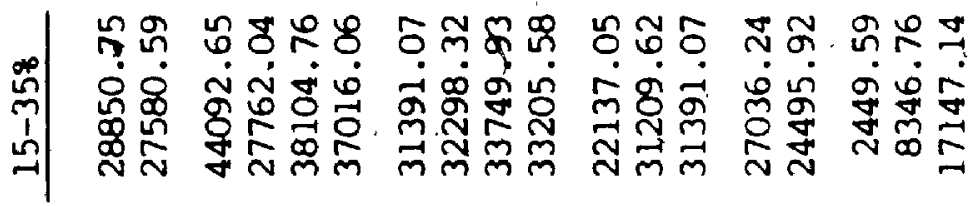

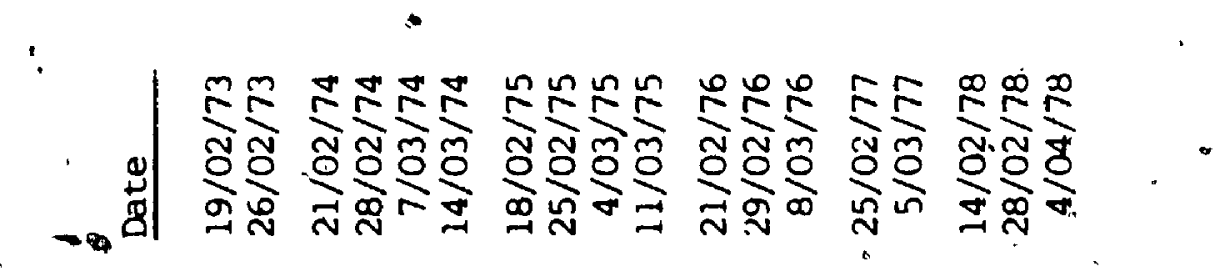




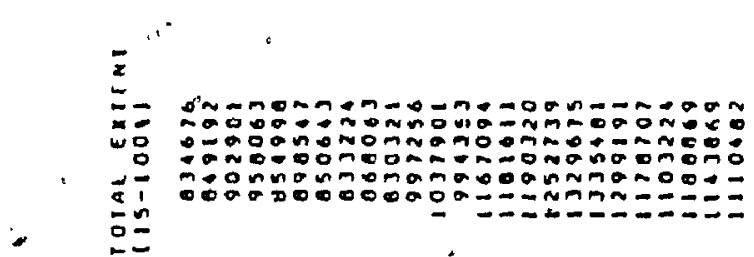

116

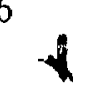

$\therefore$

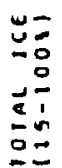

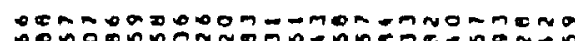
¿ñ

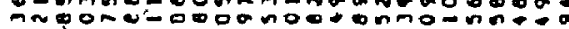

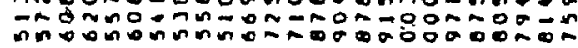
-

$\underline{\sim 0}$

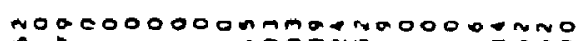
$\begin{array}{lll}0 & 0 \\ 0 & 0 & 0\end{array}$

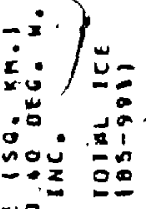

Nunnu-nnenadnn-amongnmon

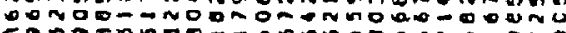
Eonaxnune-ornon tonmwando

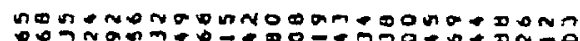
: img nuñogonan Nก⿻上丨

B

U.

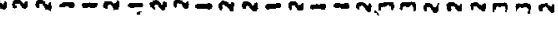

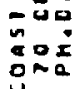

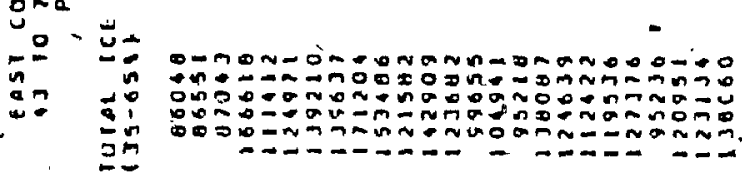

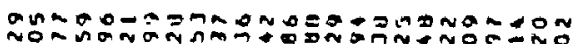

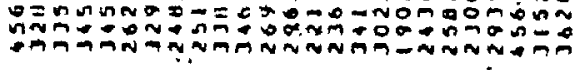
$0=$

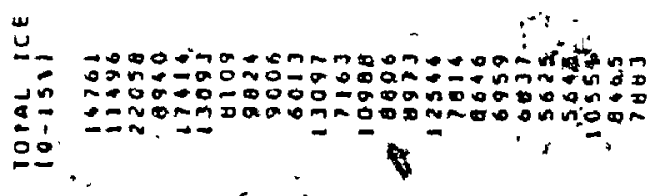

ำ

oungmu-n

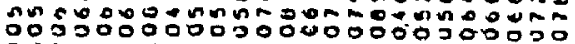

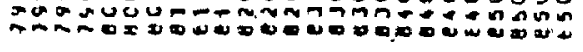



㲘 T

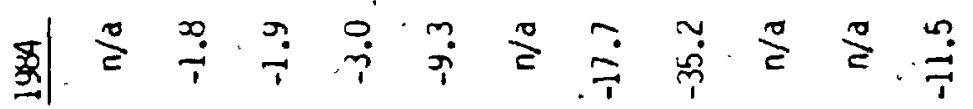

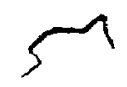

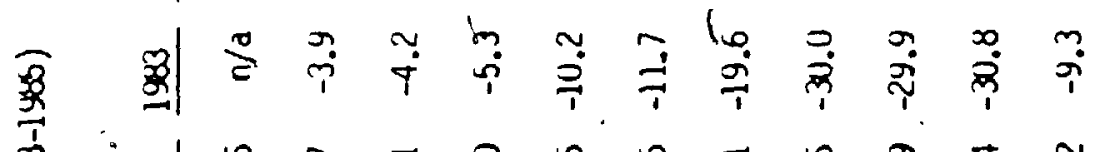

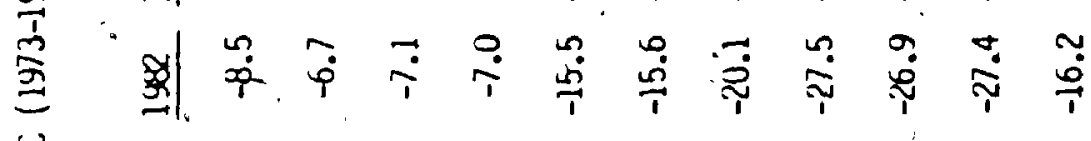

家

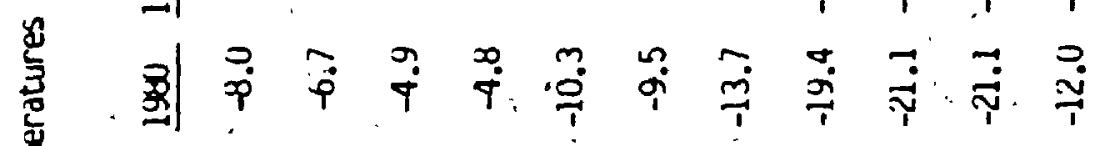

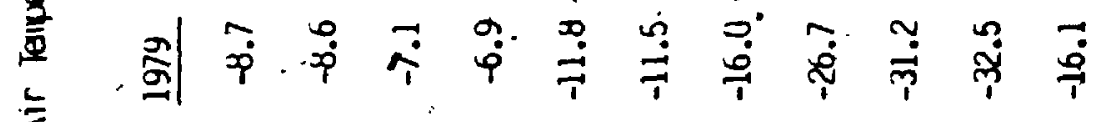

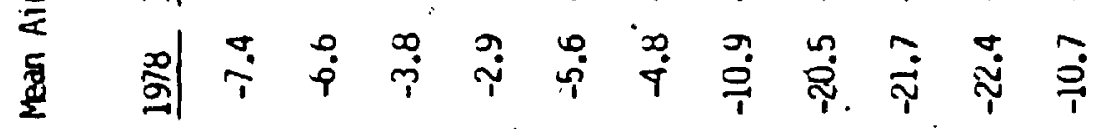

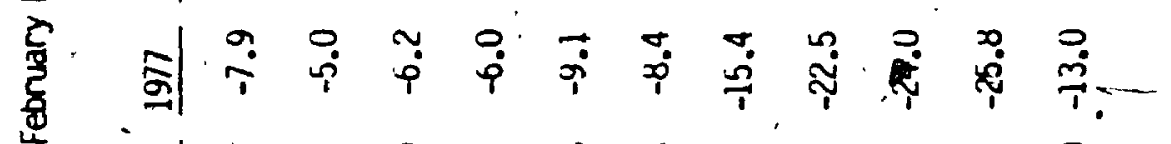

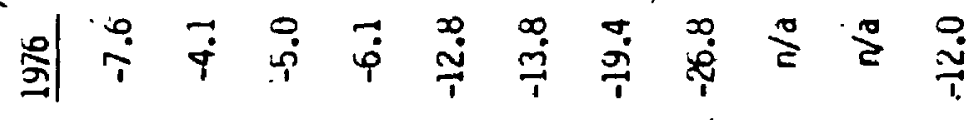

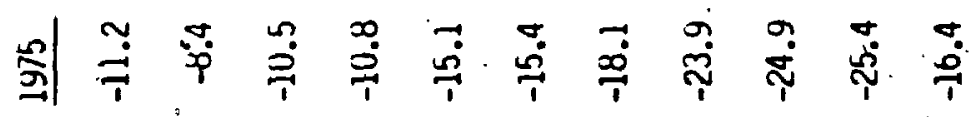

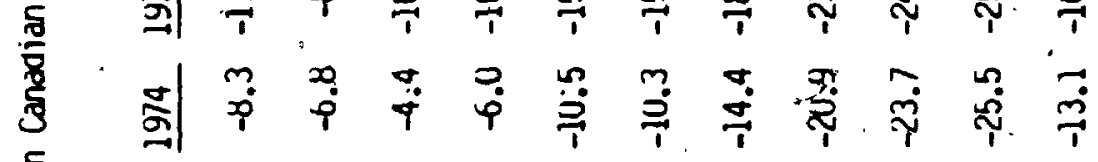

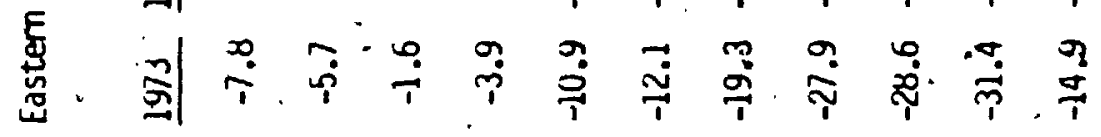

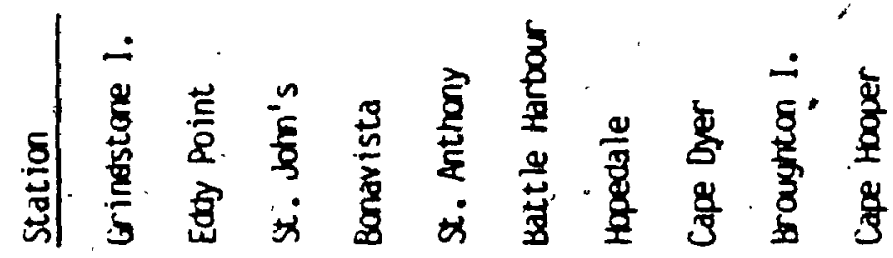

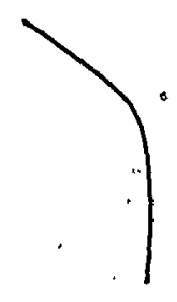

兽 


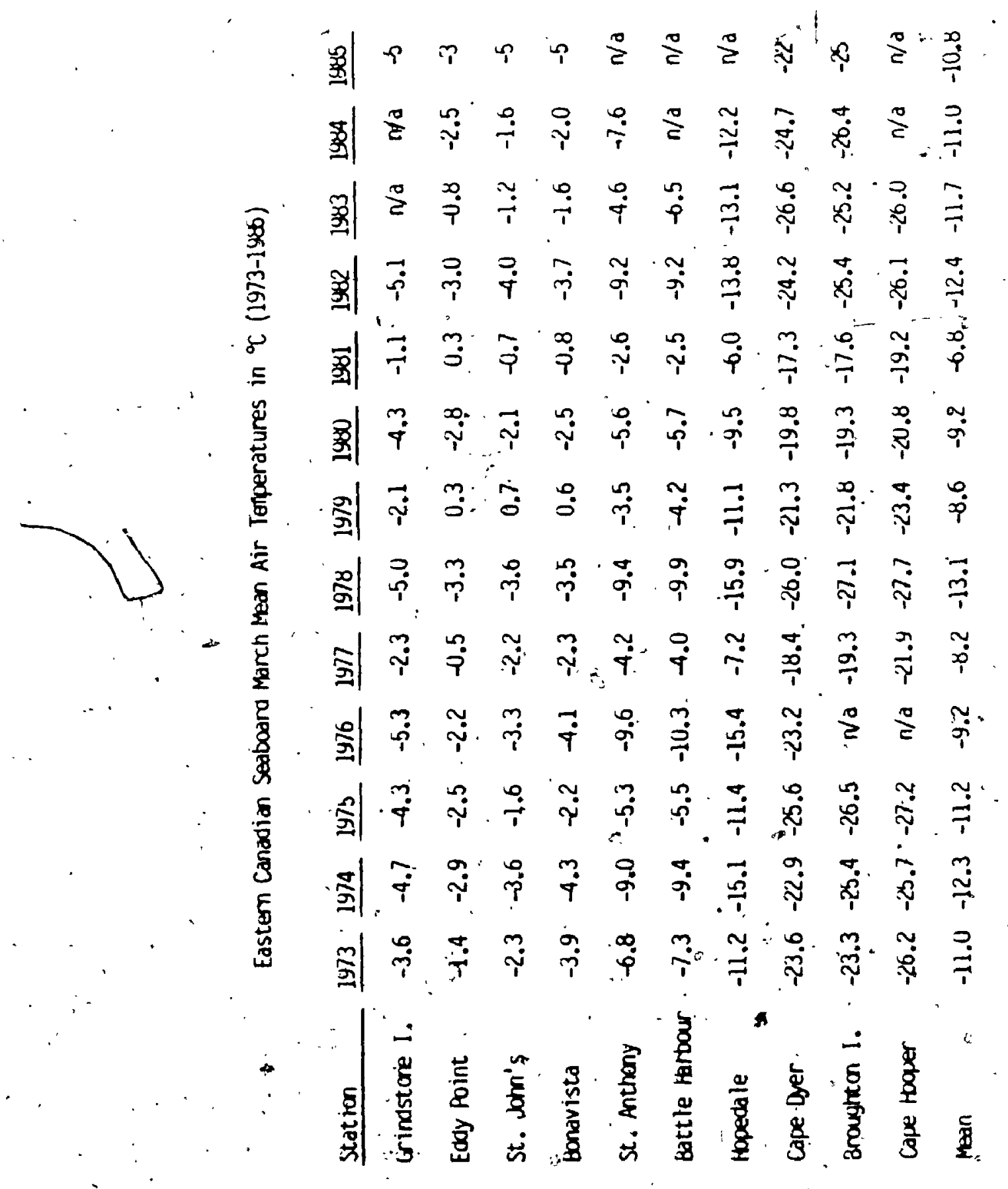




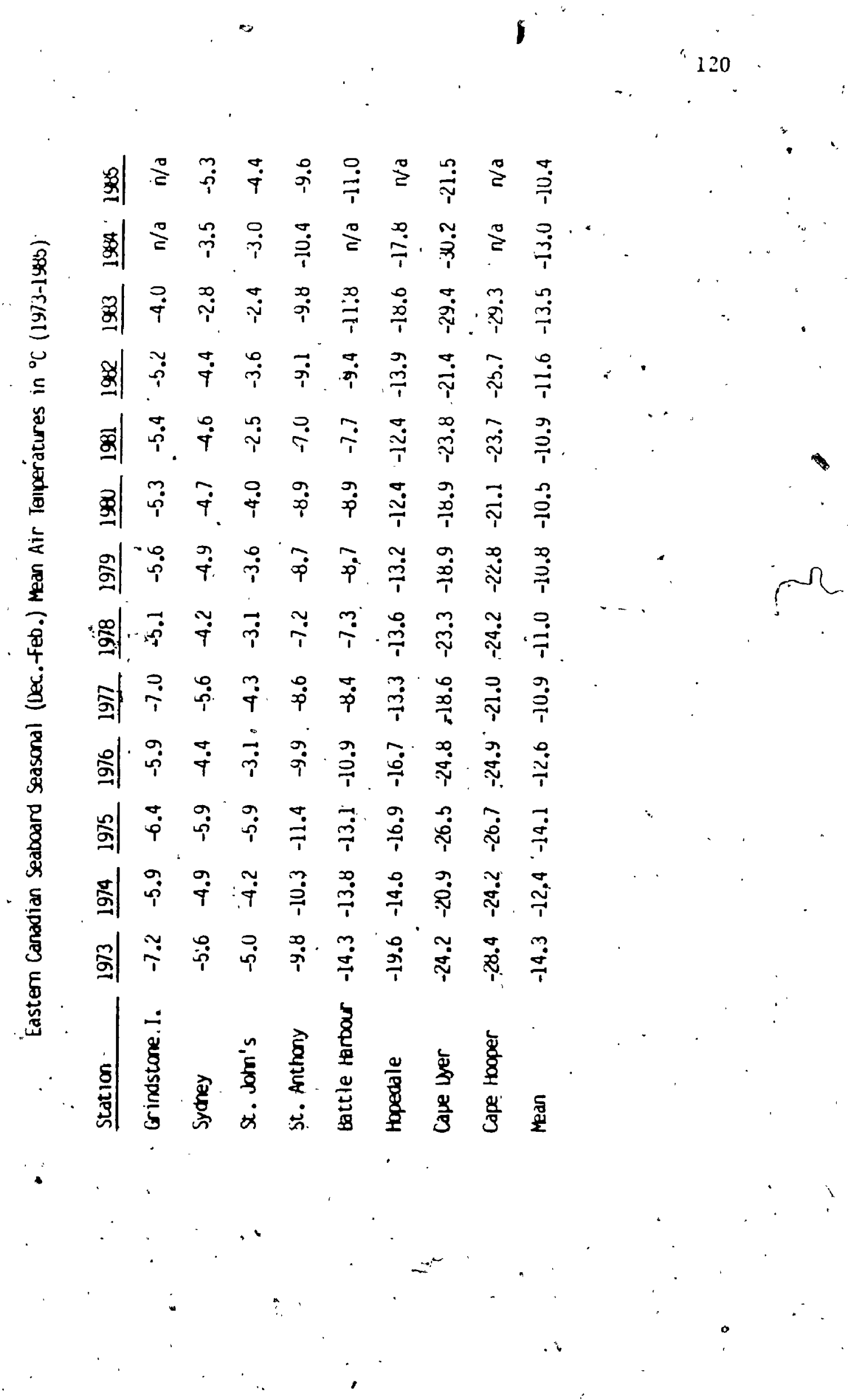




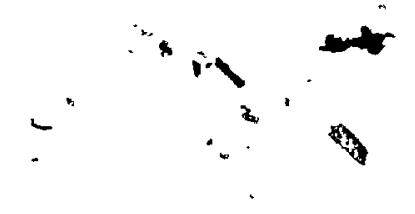

$$
\begin{aligned}
& 1
\end{aligned}
$$

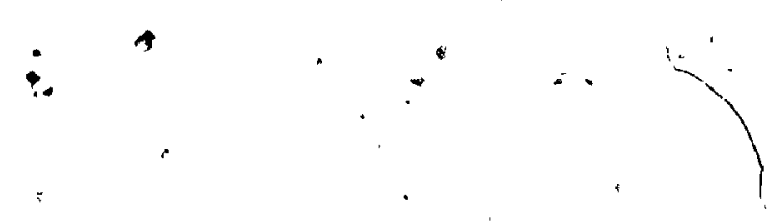

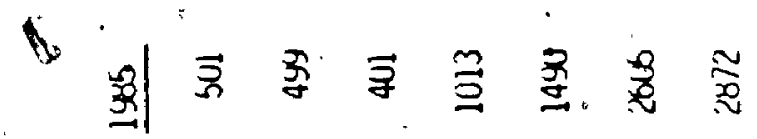

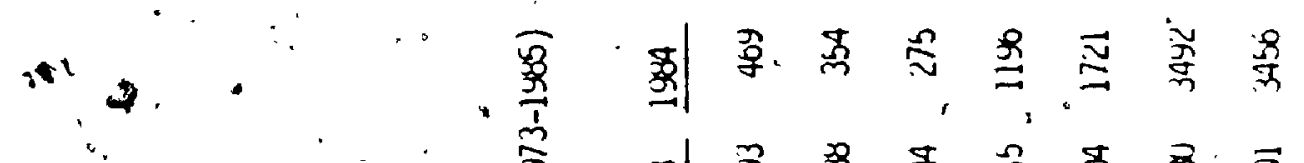

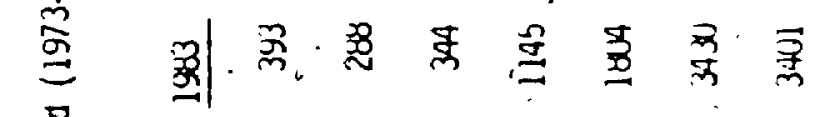

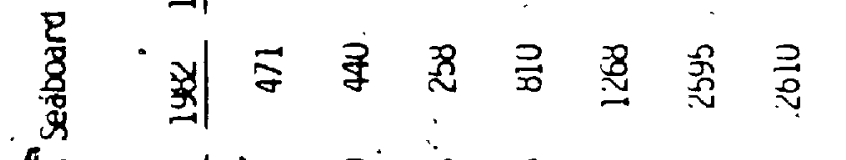

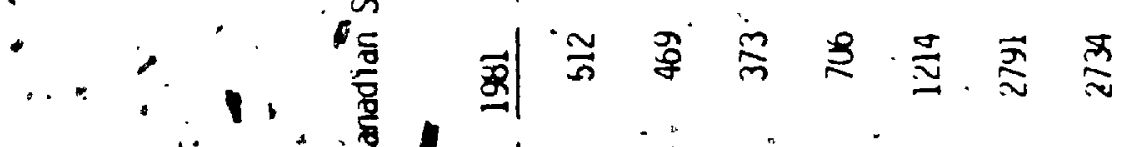

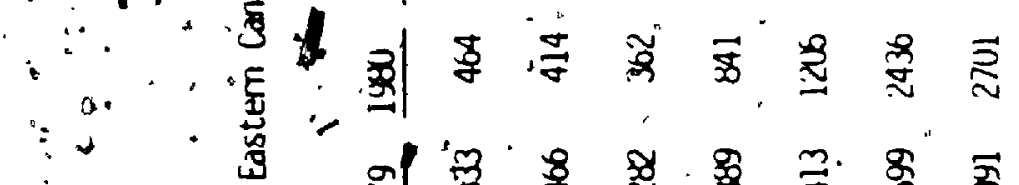

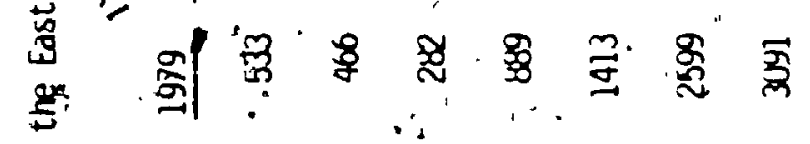

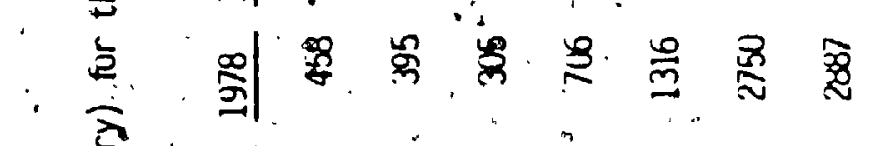

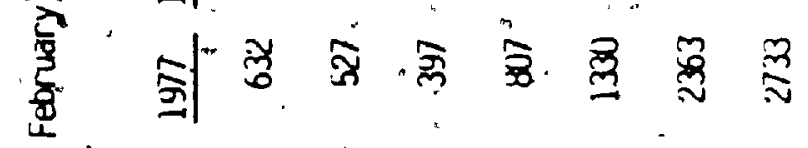

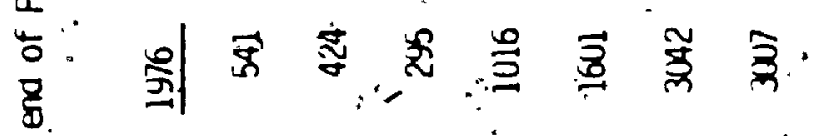

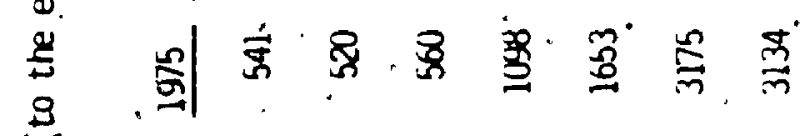

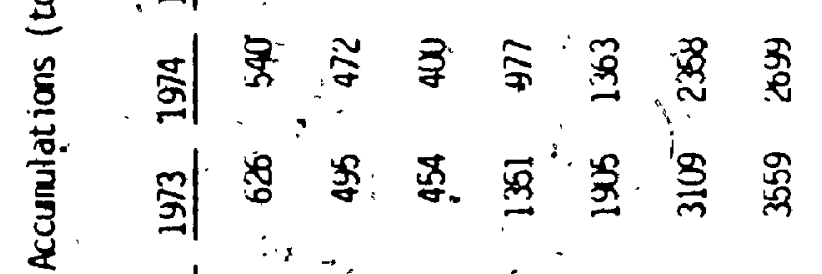

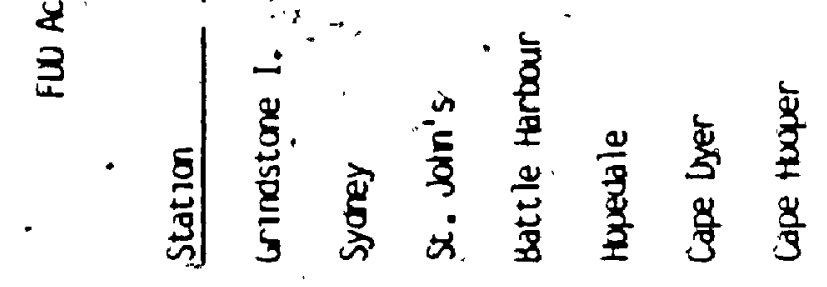




\section{APPENDIX $\mathrm{A.4}$ \\ Accessibility of Nimbus-5 ESMR and Nimbus-7 SMMR Data}

A Canadian archive of Nimbus-5 ESMR and Nimbus-7 SMMR data, including the data used for this thesis, exists at the offices of Dr. R.U. Ramseier, Senior Scientist, Ice Research and Development, of the Atmospheric Environment Service. The computer tapes can be accessed by contacting 'or. Ramseier and providing the date (day/month/year) of the tape of interest. The address to which inquiries should be directed is:

Or.R.O. Ramseier

Ice Research and Development

Atmospheric Environment Service.

Centre for Research in Experimental Space Science York University

4700 Keele Street

Downsview, Ontario

M3J 1 P 3 
BIBLIOGRAPHY.

Allison, 1. (1982). "The role of sea ice in clinate variations". Appendix $U$ in Report of the WMU/CAS-JSC-CCCO Meetiny of Experts on the Role of Sea Ice in Climate Variations, World Meteorological .organization, Geneva, Switzerland.

Atmospheric Environment Service (1980). MANICE - Manual of sea ice reporting, Environment Canada, Joronto.

Atmospheric Environment Service (1982). Ice climatoloyy notes, Ice. Climatology and Applications Division, Environment Candda, Uttawa.

Barry, R.G. (1980). "Meteorology and climatology of the seasonal sea ice zone": Cold Regions Science and Technology, 2: 133-150.

Barry, R.G., Bradiey, R.S. and J.D. Jacobs. (1975). "Synoptic climatological studies of the Baffin Island area"; in Climate of the Arctic, University of Alaska, Pp. 82-90.

Bilel lo, M.A. (1961). "Formation, growth and decay of sea ice in the Canadian Arctic Archipelago". Arctic, 14(1): 3-24.

BJerkelund, C.A., D.J. Lapp, R.O. Ramseier and N.K. Sinha (1945). "The texture and fabric of the second year ice cover at Mould Bay, Prince Patrick Island, N.W.T., April 1983". 1985 Joint International Geoscience and Remote Sensing Symposium and USNC/URSI Commission F Meeting, University of Massachusetts, Amherst, October 7-9.

Bursey, J.0., Sowden, W.j., Gates, A.D. and C.L. Blackwood (1977). "The Climate of the Labrador Sea", Fourth Interhational Conference on Port and Ocean Engineering under Arctic Conditions, September 26-30, 1977. Memorial University. of Newfoundland.

Cameron; M.A.' (1983). A.meteorological approach to the validation of sea ice parameters as depicted by passive microwave remote sensing. B.A. Honours Thesis, Carleton University, Department of Geography.

Carleton, A.M. (1984). "Synoptic sea ice - atmosphere interactions in. the Chukchi and Beaufort Seas from Nimbus-b ESMR data", Journal of leophysical Research, 89 (DS): 7245-7258.

Gavalieri, D.:and C.L. Parkinson (1981). "Large-scale variation in observed Antarctic sea ice extent and associated atmospheric circulation". Monthly Weather Review, 109: 2323-2336.

Cavalieri, D.J.jS. Martin and P. Gloersen (1983). "Nimbus-7 SMMR 
observations of the Bering Sea ice cover during March 1979". Journal of Geophysical Research, 88: 2743-2754. .

Cavalieri, D.J., Gloersen, P. and W.J. Campbell (1984). "Uetermination of sea ice parameters with the NIMBUS 7 SMMR". . Journal of Geophysical Research, $89(D A): 5355-5369$.

Comiso, J.C. (1983). "Sea ice effective microwave emissivities from 1. Satellite passive microwave and infrared observations". Journal of Geophysical Research, 88: 7686-7704.

Comiso, J.C., S.F. Ackley and A.L. Gordon (1984). "Antarctic sea ice microwave signatures and their correlation with in situ ice observations". Joyrnal of Geophysical Research, 89.(C1): 662-672.

Comiso, J.C. and H.J. Zwally (1984). "Concentration gradients ana growth/decay characteristics of the seasonal sea ice cover". Journal of Geophysical Research; 88(C5): 8081-8103.

Crane; R.G. (1978) "Seasonal-variations of sea ice extent in the Davis Strait - Labrador Sea area and relationships with synoptic-scale atmospheric circulation". Arctic, $31(4)$ : 434-4.47.

Crane, R.G. (1981). "Surface-atmosphere interactions over the polar oceans". Progress in Physical Geography", 5(2): 186-216.

Crane, R.t. (1983)." "Atmosphere - sea ice interactions in the Beaufort/Chukchi Sea and in the European sector of the Arctic". Journal of Geophysical Research, 88(C7): 4505-4523.

Crane, R.G., Barry;, R.G. ána H.J. Zwally (1982). "Analysis of atmosphere-sea ice interactions in the Arctic Basil using "ESMR microwave data". International Jouknal of Remote Sensir.?., 3ij): $259-$ 276.

Dey, B. (1980). "Seasonal and annual váriations in ice cover in Baffin: Bay and northern Davis Strait". Canadian Geographer, $24(4)$ : 368-384.

Uunbar, M.J. (1982). "Twentieth century marine climatic change in the Northwest Atlantic and Subarctic regions". Northwest Atlantic Fisheries Organitation Scientific Council Studies, 5: 7-15.

Eastern Uffstiore News" (1985). "Pack ice prevents Grand Banks artlling". April, p. 3.

- Environment Canada (1982). Canadian Climate Norma 1s, 1951-1980, Volume 4: Degree Days, Toronto.

Eppler, D.T. (1983). Assessment of potential SSM/I ice productex in 
light of ESMR and SMMR ice classsification al yorithms, NORUA Technical Note 220, Mississippi.

European Space Agency (1985). - A Programme for'International Polar Oceans Research (PIPOR). Report of the PIPOR Science Working Group, Paris, France, 4ap.

Gloersen, P., Nordberg, W., Schmugge, T.J. and T.T. Wr theit - (1973). "Microwave signatures of first-year and multiyear sea ice". Journal of Geophysical Research, $78(18) ; 3564-3572$.

Gloersen, P., ToT. Wilheit, T.C. Chang and W. Nordberg (1974). "Microwave maps of the polar ice of the earth": Bulletin American Meteorological Society, 5b(12): 1442-1448.

Gloersen, P. and Fat. Barath (1977). "A scanniny multichannel micrawave radiometer for Nimbus-G and SeaSat-A". IEEE Journál út Oceanic Engineering, UE -2(2): 172-178.

Gloersen, P. and L. Hardis (19.78). "The scanniny multichannel microwave radiometér (SMMR) experimerit" in Nimbus 7 Users'Guide, (C.R. Madrid, ed.), NASA Goddard Space F.light Center, Greenbelt, Maryland.

Gustajtis, KaA. (1979). "Océanography and climatology of the Labrador Sea" in 0 il Spill Scenagio for the Labrador Sea, Environinental Protection Service, Environment Canada; Ut tawa'.

Hammona, R. and P.S. McCullagh (1978). Quantitative techniques in geography: an introduction, clarendon Press, :0xford.

Hibler, W.O. (1980). "Sea ice grawth, drift and decay", in Dynamics of snow and ice masses, (S. Colbeck, ed.), Academic press, New York,"pp. 141-209.

Hol 1 inger, J.P., Troy, B.E., Ramseier, R.O., Asmus, K.W., Hartman, M.F. and C.A. Luther (1984). "Microwave emission from high Arctic sea ice during freeze-up". Journal of Geophysclal Research, 89 (C5.): 8104-8122.

Jacobs, J.D. and J.P. Nówell (1979): "Recent-year-to-year variations in seasonal temperatures and sea ice conditions. in the Eastern Canadian Arctic". Arctic, 32(4): 345-354.

Johnson, C.M. (1980). "Wintertime Arctic sep ice extremes and the simul taneous atmospheric circulation". Monthly Weather Review, 108: , 1782-1791.

Keen, R.A. (1977). "The response of Baffin Bay ice conditions to 
changes in atmospheric circulation patterns". Fourth International Cónference on Port and Ucean Engineering under Arctic Conditions, Memorial University of Newfoundland, September 26-30, 1977.

Kellogg, W.W. (1975). "Climatic feedback mechanisms involving the polar regions", in Climate of the Arctic University of Alaska, pp. $111-116$.

Kukla, G.J. (1978). "Recent changes in snow and ice", in Climatic Change, (J. Gribbin, ed.), Cambridge: Cambridge University Press, pp. 114-129.

Lamb, H.H. and H.T. Morth (1978). "Arctic ice, atmospheric circulation and world climate". The Geographical Journal, 144(Part 1): 1-22.

Lazier, JR.N. (1980). "Panel on oceanography". Labrador Ice Dynamics Experiment Workshop, Memorial University of Newfoundland, March 6-8, 1980, pp. 82-85.

LeBl ond, P.H. (1982). "Satellite observations of Labrador Current undulations". Atmosphere-Ocean, $20(2): 129-142$.

Lockwood, J.G. (1979). Causes of Climate. London: Edward Arnold Ltd., $260 \mathrm{pp}$.

Markham, W.E. (1976). "Variability" of ice seasons on the Eastern

"Canadian-Seaboard". International Commission for the Northwest Atlantic Fisheries Special Publication No. 9, pp. 29-40.

Markham, W.E. (1980). Ice At las - Eastern Canadian Seaboard, Atmospheric Environment Service, Environment Canada, Toronto.

Maykut, G.A. (1978). "Energy exchange oüer young sea ice in the Central Arctic". Journal of Geophysical Research, 83(C7): 3646-3658.

Moreau, T.A., E.L. Sudeikis, I.G. Rubinstein and F.W. Thirkettle (1985). A study and report on operational ice mapping, NIMBUS-7, - SMMR. Final Report for'Ice Branch, Atmospheric Environment Service, dittawa.

Mortsch, L.D.b Agnew, T., Saulesleja,. A. and V.R. Swail (1985). Marine Climatological Atlas - Canadian East Coast, Canadian Climate Centre Report No. 85-11, Atmospheric Environment Service, Downsview, Unpublished-Manuscript.

Mul lane, T.F. (1980). "Operational use of satellite imagery in the Canadian ice program". Sixth Canadian Symposium on Remote Sensing, Halifax; Nova Scotia, May 21-23, 1980, pp. 18-32. 
NASA (1979). Ice and Climate Experiment. Report of. Scrence and. Applications Working Group, Goddard Space Flight Center, Greenbelt, Maryland.

NASA (1984). Passive microwave remote sensing for sea ice research. Keport of the NASA Science Working GToup for the Special Sensor Microwave Imager (SSM/I), Washington, D.C.

Njoku, E.G. (1982). "Passive microwave remote sensing of the earth from space - a review". Proceedings of the IEEE, 7U(7): $728-750$.

Owens, A.E. (1983). A time series study of Gulf of St. Lawrence Sed ice conditions using Nimbus-7 SMMK dat. B.A. Honours Thesis, Carleton University, Department of ieograph.

Uwens, A.E. and R.0. Ramseier (1984). Ice at las of tastern Canada based on Nimbus-5 passive microwave data (1972-1977). Lce kesearch and Development Report 83-U4, Atmospheric Environment Service, ottawa.

Parkinson, C.L. and D.J. Cavalieri (1982)." "Interanaual sea-ice variations and sea-ice/atmosphere interactions in the-Southern Ocean, 1973-1975". Annals of Glaciology, 3: 249-254.

Kamsejer, R.0: (1983). Passive microwave remote sensing of sea ice from research to operations. Canadian Meteorological and Oceanographic Society Speaking Tour $1983 / 84$.

Rogers, J.C. (1985). "Atinospheric circulation changes associated with the warming over the Northern North Atlantic in the 1920s". Journal of Climate and Applied Meteorology, 24: 1303-1310.

Rubinstein, 1.G., Bunn, F.E. and R.0. Ramseier (1985). "Nimbus-7 mičrowave radiometry of ocean sitrface winds and sea ice". Presented at the Nineteenth International Symposium on Remote Sensing of Environment, Ann Arbor, Michigan, October 21-25, 1985.

Rubinstein, I.G. and R.0. Ramseier (1985). "Scientific application of passive microwave satellite data for ice monitoring and research". Proceedings of a Conference of the Use of Satellite Data in Climate Mode 1s, Alpach, Austria, June 10-12, 19985, pp. 117-123.

Saulesleja, A. and D.W. Phililips (1982). Meteorological condjtions and their impacts over the Northwest Atlanti: in the $1970^{\prime \prime} \mathrm{s}^{\prime \prime}$. Northwest Atlantic Fisheries Organization Scientific Council Studies, 5: $17-32$.

Schel 1, I.I., Corkum, D.A. and E.N. Sabbagh (197.5): "Recent climatic changes in the Eastern North American Sub-Arctic", in Climate of the : 
Arctic, University of Alaska, pp. 76-81.

Skidmore, J.M. (1979). "Labrador Sea synoptic ice description" in vil Spili Scenario for the Labrador Sea, Environmental Protection Service, Environment Canada, ottawa.

stein, M. (1982). "Autumn temperature anomalies of the Labador Current, 1969-80". . Northwest Atlantic Fisheries Organization Scientific Council Studies, Number 5: 79-80.

Svendslen, E., K. Kloster, B. Farrelly, O.M. Johannessên, J.A. Johannessen, W.J. Campbell, P. Gloersen, U. Cavalieri and C. Matzler (1983). "Norwegian Remote Sensing Experiment: Evaluation of the Nimbus-7 scanning multichannel microwave radiometer for seg ice research". Journal of Geophysical Research, 88: 2755-2769.

Swift, C.T., L.S. Fedor and R.0. Ramseier (1984). "An alyorithm to measure sea ice concentration with microwave radioneters". "Journal of Geophysical Research, 90: 1087-10.99.

Symonds, G. (1984). "Sea ice as an indicator of climate change" in BIO" Review ' 84 , Bedford Institute of Oceanography, Dartmouth, Nova Scotia, pp. $24-26$.

Thirkettle, F.W. (1985). "A near real-time data syštem for satellite passive microwave ice maps". Presented at the Nineteenth International Symposium on Remote Sensing of Environinent, Ann Arbor, Michigan, October 21-25, 1985.

Trites, R.W. (1982). "Overview of oceanographictonditions in NAFU Subareas 2, 3 and 4 during the 1970-79 decade". Northwest At lantic Fisheries Urganization Scientific Council Stuaies, Nymber 5: 51-78.

Trites, R.W: (1984). "Sea-surface temperature trends and patterns in the Northwest Atlantic". BlO Review "84, Bedford Institute of Oceanography, Dartmouth, Nova Scotia, pp. 18-20.

Trites, R.W. and K.F. Drinkwater (1983). "Overview of envrionmental conditions in 1982 within the NAFO convention area". Northwest At lantic Fisheries Organization Scientific Council Report, 83/VI/23: 42pp.

Ulaby, F.T.; Moore, B.K. and A:K. Fung (1981). Microwave remote sensing, active and passive - Volume 1, Microwave remote sensing fundamentals and radiometry, Addison-Wes ley Publishing Company, Rearing, Massachusetts.

Ulaby, F.T. and K.R. Carver (1983): "Passive microwàve radiometry". Chapter 11 in Manual of Remote Sensing, 2nd Edition, (D.S. Simonett 
and F.T. Ulaby, eds.). American Society of Photogrammetry, Falls Church, Virginia, pp. 475-516.

Van Loun, H. and R.A. Madden (1983). "Interannual variations of lllean monthiy sea-level pressure in January". Journal of Cl imate and Applied Meteorology, 22: 687-692,

Vant, M.R., R.O. Ramseier and V."Makios (1978). "The complexdielectric constant of sea ice at frequencies in the range of $0.1-40$ GHz". Journal of Applied Physics, 49(3), Part 1: 1264-1280.

Waanams, $P$. and J. Lever (1985). LIMEX - A Labrador ice maryin experiment, Preliminary science plan. Centre for cold Ucean Resources Engineerjing, St. John's, Newfoundland.

Walsh, J.E. (1983). "The role of sea ice in climatic variability: Thearies and evidence". Atmosphere-Ocean, 21(3): 229-242.

Walsh, J.E. ana C.M. Johnson (1979). "Interannual atmosuneric variability and associated fluctuations in Arctic sea ice extent". - Journal of Geophysical Research, $84(C 11)$ : 6915-6928.

Wil heit, T.T. (1972): "The electrically scanning inicrowave radiometer (ESMR) experiment" in The Nimbus 5 Users" Guide, (R.R. Sabdtini: - ed.), NASA Goddard Space-Flight Center, Greenbelt, Marylana.

Wilneit, T.T. (1975). "The electrically scanning microwave radiometer (ESMR) experiment" in The Nimbus-6 Users' Guide, (J.E. Sissala, ed.), NASA Goddard Space Flight Center, Greenbelt, Maryland.

Witheit, T.T. (1978). "A review of applications of micrlowave radiometry to oceanography". Boundary-Layer Meteorology, $\lambda^{5}$ : $277-$ 293.

Williams, DR.P. (1986). Nimbus-7 satellite passive microwave sea ice models - validation and applications. Unpublished M.Sc. Thesis, Centre for Research in Experimental Space Science,. York. University, Toronto.

Zwally, H.J. "(1984). "Observing polar ice variabilioy". Annals of. Glaciology, $5: 191-198$.

Zwally, H.J. and P. Gloersen. (1977): "Passive microwave images of the polar reyions and research app'ications". Polar Record, $18(116)$ : $431-450$.

Zwally, H.J., Comiso, J.C., Parkinson, C.L., Campbel l, W.J., Carsey, F.D. and $P_{0}$, Gloersen (1983). Antarctic sea ice, 1973-1976: Satellite passive-microwave observations, NASA, Scientific ana 


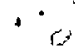

$\therefore$

130

Technical Information Branch, Washington, D.ć, 206 p.

Ludo, N.N. (1945). Arctic I CB. U.S. Naval Electronics Laboratory, San Diego, California, $491 \mathrm{p}$ : 

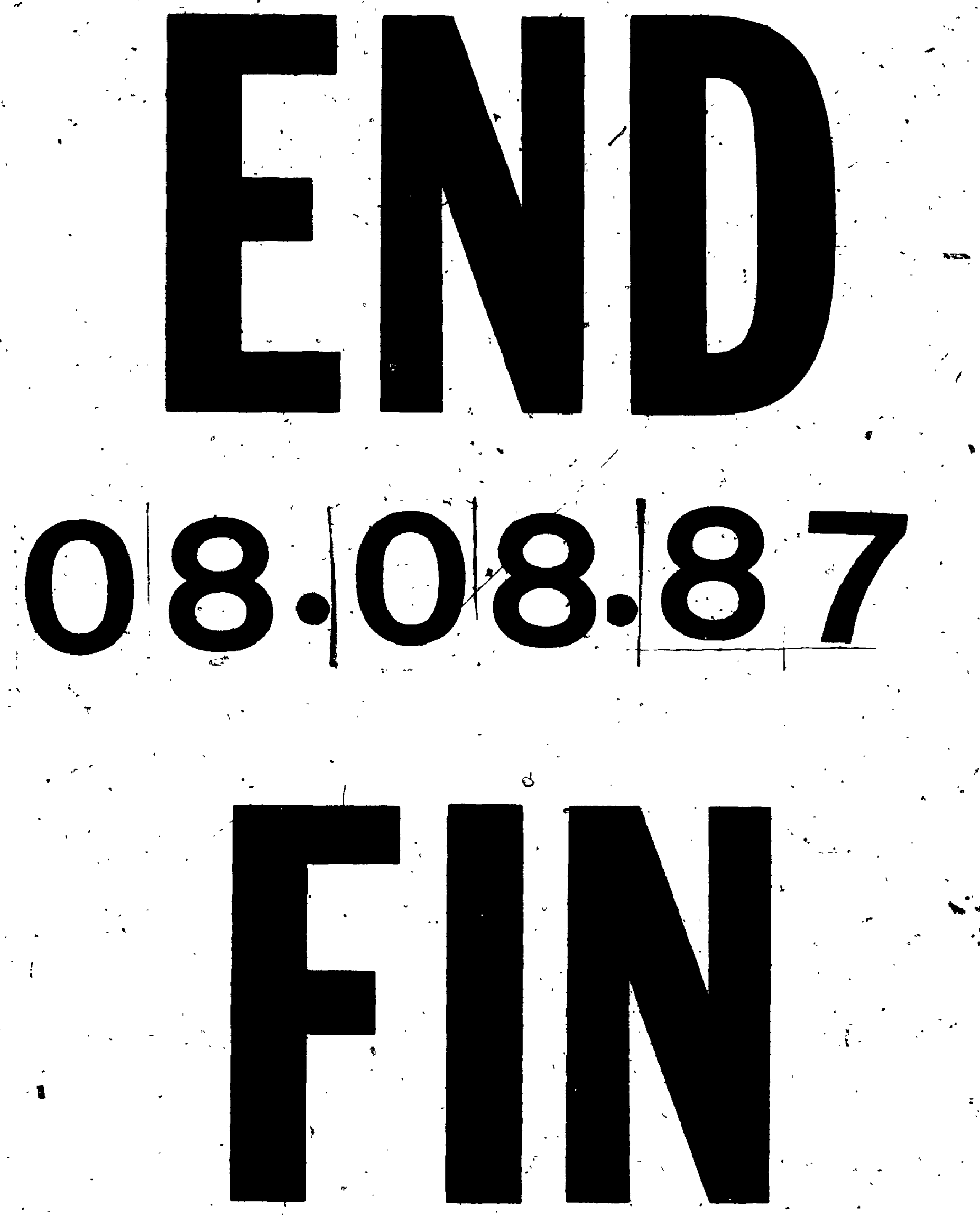